Illinois State University

ISU ReD: Research and eData

Theses and Dissertations

3-29-2021

\title{
Exceptional Paternal American Heroes Triumph Over Big Bad Terrorists (Again): The Storied Episodes Of Three Presidential Addresses Announcing The Elimination Of Another Middle Eastern Terrorist Threat
}

Maura Freeman

Illinois State University, maurafreeman274@gmail.com

Follow this and additional works at: https://ir.library.illinoisstate.edu/etd

Part of the Communication Commons

\section{Recommended Citation}

Freeman, Maura, "Exceptional Paternal American Heroes Triumph Over Big Bad Terrorists (Again): The Storied Episodes Of Three Presidential Addresses Announcing The Elimination Of Another Middle Eastern Terrorist Threat" (2021). Theses and Dissertations. 1368.

https://ir.library.illinoisstate.edu/etd/1368

This Thesis is brought to you for free and open access by ISU ReD: Research and eData. It has been accepted for inclusion in Theses and Dissertations by an authorized administrator of ISU ReD: Research and eData. For more information, please contact ISUReD@ilstu.edu. 
EXCEPTIONAL PATERNAL AMERICAN HEROES TRIUMPH OVER BIG BAD TERRORISTS

(AGAIN): THE STORIED EPISODES OF THREE PRESIDENTIAL ADDRESSES

ANNOUNCING THE ELIMINATION OF ANOTHER

MIDDLE EASTERN TERRORIST THREAT

\section{MAURA FREEMAN}

\section{Pages}

In 2001, the United States of America was the target of a vicious terrorist attack. In 2003, President George W. Bush announced that Americans were the mighty heroes responsible for capturing Saddam Hussein and bringing him to justice, even though Hussein was not the terrorist responsible for 9/11. Eight years later, President Barack Obama broke the news that Americans succeeded in assassinating Osama bin Laden, the true villain who orchestrated 9/11. One administration later, President Donald Trump proclaimed Americans had intervened to protect the world by eliminating another terrorist threat, Qasem Soleimani. I analyze these three presidential addresses as episodes in an overarching narrative of American exceptionalism, exemplarism, interventionism, and paternalism. In so doing, this project may illuminate a recurring pattern of eliminating terrorist threats as part of a campaign strategy in the last year of these leaders' first terms in the White House, and start of their re-election campaigns.

KEYWORDS: president; terrorism; terrorist; capture; assassination; announcement; speech; rhetoric; George W. Bush; Barack Obama; Donald J. Trump; Saddam Hussein; Osama bin 
Laden; Qasem Soleimani; exceptionalism; exemplarism; interventionism; presidential paternalism 
EXCEPTIONAL PATERNAL AMERICAN HEROES TRIUMPH OVER BIG BAD TERRORISTS

(AGAIN): THE STORIED EPISODES OF THREE PRESIDENTIAL ADDRESSES

ANNOUNCING THE ELIMINATION OF ANOTHER

MIDDLE EASTERN TERRORIST THREAT

MAURA FREEMAN

A Thesis Submitted in Partial

Fulfillment of the Requirements

for the Degree of

MASTER OF SCIENCE

School of Communication

ILLINOIS STATE UNIVERSITY 
(C) 2021 Maura Freeman 
EXCEPTIONAL PATERNAL AMERICAN HEROES TRIUMPH OVER BIG BAD TERRORISTS

(AGAIN): THE STORIED EPISODES OF THREE PRESIDENTIAL ADDRESSES ANNOUNCING THE ELIMINATION OF ANOTHER

MIDDLE EASTERN TERRORIST THREAT

MAURA FREEMAN

COMMITTEE MEMBERS:

Joseph Zompetti, Chair

Stephen Hunt

Joseph Blaney 


\section{ACKNOWLEDGMENTS}

It is done.

Between the campaigns (and there were many), teaching, and full time job of being a graduate student... There were more than a few moments in which I was not entirely convinced this thesis project would ever be done. Yet here we are. We reached the end of my time as a graduate student with the defense of this thesis project and as such, I have a few people I need to thank for helping me reach this point.

To Aunt Wilma, thank you for making my education possible. Without you, no one in my family would be where we are today. I am so proud to call you my aunt. And I am so grateful to have such an excellent role model in my life.

To my parents, thank you for pushing me to go further, to try harder, and to overcome each roadblock. Thanks, dad, for showing me that at a young age that school may not be easy, but it will always be worth it. Thank you, mom, for running for office-for renewing my passion for politics and showing me how to stretch the limits of possibility. And most importantly, thank you for continuing to pick up the phone. To Grandma Linda, thank you for answering when mom couldn't... I love you so much!

To my siblings, thank you for catching me each time I start to fall. To Ian, thank you for Monday night Encounter, Thursday night dinners, and 2 AM calls. You are the best brotato, and I had so much fun attending the same school for the first and only time. I give you permission to kick ISU's butt when I leave. You and your many majors are going to crush it!

To Sisi, you know me perhaps better than everyone else in the world, and I love you so much for it. You are my longest and best friend and I am so grateful to have you in my life. I am so grateful we were able to share the joys and panic attacks of grad school together. You're 
going to do great things. And I cannot wait until next semester, when we have both graduated our eighteenth year of schooling. Our educations are officially old enough to vote- and I don't think the world will ever be ready for these two educated women who are always ready to fight the man.

To my rhetoric buddy, Rocky, thanks for being you, for making this thesis way more fun to write, and for all the shenanigans in Fell Hall.

And of course, thank you so much, Dr. Zompetti, Dr. Blaney, and Dr. Hunt. You comprised the best thesis committee a gal could ever ask for!

This thesis is dedicated to what's next?

M. F. 


\section{CONTENTS}

Page

ACKNOWLEDGMENTS $\quad$ i

CHAPTER I: INTRODUCTION 1

CHAPTER II: LITERATURE REVIEW

Presidents Define American Reality 11

$\begin{array}{ll}\text { American-isms } & 14\end{array}$

$\begin{array}{ll}\text { American Exceptionalism } & 15\end{array}$

$\begin{array}{ll}\text { American Exemplarism } & 16\end{array}$

$\begin{array}{ll}\text { American Interventionism } & 17\end{array}$

$\begin{array}{ll}\text { Rhetoric of Innocence } & 18\end{array}$

Us against the world: dualism and the vilification of terrorists 21

Dualism: An "Us” versus “Them” Dichotomy 21

Unconscionable "Evil” $\quad 25$

Presidential Paternalism: Only I Can Protect You 27

President George W. Bush (2001-2008) 29

President Barack Obama (2009-2016) 32

President Donald Trump (2017-2020) 33

$\begin{array}{ll}\text { Conclusion } & 38\end{array}$

$\begin{array}{ll}\text { CHAPTER III: METHODS } & 40\end{array}$

$\begin{array}{ll}\text { Narrative Paradigm: Stories We Tell Ourselves } & 40\end{array}$

Close Textual Analysis: Words and Strategies to Tell our Stories 43

Three Texts: The Objects of Analysis $\quad 44$

Methodology for Analysis $\quad 45$

CHAPTER IV: GEORGE W. BUSH AND THE CAPTURE OF SADDAM HUSSEIN 48

CHAPTER V: BARACK OBAMA AND THE ASSASSINATION OF OSAMA BIN LADEN 70 
$\begin{array}{ll}\text { Presidential Setting, Presidential Man } & 103\end{array}$

$\begin{array}{ll}\text { Reliable (and Unreliable) Narrators } & 108\end{array}$

The Flag Around Which We (Might Not) Rally 115

$\begin{array}{ll}\text { Implications } & 119\end{array}$

REFERENCES 125 


\section{CHAPTER I: INTRODUCTION}

The date is July $18^{\text {th }}, 2020$, as I sit at the kitchen table of my rented apartment in Normal, Illinois, writing the introductory paragraph to my master's thesis. I am staring at a bush outside my kitchen window; it is swaying in a too-warm breeze, sat up against a clear and cloudless blue sky. I just finished my lunch, which reminds me that only half a day has passed since the world lost another civil rights great; a man I had the unique pleasure of meeting just four years ago when John Lewis toured with his graphic novel straight through the heart of the Midwest and stopped at my university. Before that, it seems like just yesterday that the country learned that cancer has returned to ravage the frail body of our beloved Justice Ruth Bader Ginsburg. And our bodies are still under constant threat of a potentially deadly virus that has infected and affected the globe. Our wellbeing is under attack by all the people we pass in the grocery store who refuse to wear their masks.

The world feels like it is cracking at the seams and I, for one, am terrified.

But I digress, so let us return to that bush — that bush swaying against a sky blue backdrop clearer than any sky I can recall seeing. My parents tell me that the sky looked something like this for a short time when I was four years old —after planes struck the World Trade Center and the Pentagon and the country stopped flying. Although I do not remember the color of the sky that September, I do remember, and I doubt I can ever forget, the events of September 11, 2001.

Theoretically, I should not remember this time. I was only four, after all. But my uncle was in the Pentagon and we could not find him. Phone lines were jammed with desperate calls seeking the status of loved ones. Gas stations had long lines of their own, as people filled their tanks and placated their terror for the time being: at least we got gas before the price spiked. I 
believe we were in the line at a Shell station in Danville, Illinois when my mother's top-of-theline flip phone rang announcing "Dennis is okay." My uncle and his coworkers evacuated his unit to the Arlington National Cemetery, where workers stood among tombstones of the fallen and waited for debris to fall from the five-sided building. My mother sighed with relief. And my little world resumed spinning at least for a little while.

Then there were the color-coded warnings from Homeland Security that flashed next to news anchors' faces every night after dinner. We held our breath to see if the indicator would ever leave the orange space, and prayed that the little arrow would inch closer to green. Years passed before we ever got a chance to exhale, and that relief only arrived after Homeland Security finally eliminated the color-coded threat level system in 2011 (Department of Homeland Security, 2021).

Whereas my peers in preschool had nightmares about dragons and pirates and showing up to school in their underwear, I was subjected to nightmares of a faceless demon I only heard about from the television in another room. The thought of Saddam Hussein terrorized me even in my sleep. I saw his face for the first time when the nightly news anchor announced Hussein's capture on December 30,2006. At the time, the news felt like a late Christmas present. I remember sitting on the living room carpet and watching President George W. Bush deliver his address announcing this momentous American victory. By that point, I was already infected with an infatuation for presidential speeches, so I watched it again and again as snippets dominated the news cycle for days following the address. And I recall admiring his strength and feeling protected by the air of the presidency, even though I cannot remember the words he specifically chose to protect us. 
Before I even had a chance to sleep soundly, it seemed, our nation set its eyes on a new terrorist target. This time, a long scraggly beard attached to one Osama bin Laden haunted my adolescent dreams. I was old enough to understand he posed little threat to my family and me, since we lived in rural Illinois, where there were more cow pastures than people. That rational thought hardly prevented our quiet celebration when President Barack Obama walked up to that podium in the East Room to announce U.S. troops had laid rest to bin Laden. That speech dominated my YouTube search history for several weeks following its delivery.

Most recently, President Donald Trump made a similar announcement of his own, and I remember the ensuing chaos as Trump's words about Qasem Soleimani tumbled from his lips. I recall a CNN alert flashing across the screen of my smart phone, followed almost immediately by a text message notification from my best friend: “So... we going to war?" That evening, just as now in 2020, it felt like the world (or at least the United States) was falling in shambles at my feet. Although I did not seek the footage of President Trump's speech, my news programs gave me no choice but to watch over and over again, before pundits moved on and the world seemingly forgot about the assassination of Soleimani.

While the subjects of each of these three presidential speeches no longer star in my nightmares, the speeches now haunt my graduate research. Decades after September 11, 2001, the stories we gleaned from that experience shape not only our own frames of references, but also our national sense of identity as they are reiterated in new narratives disguised as presidential addresses. Each of these presidential actions and speeches, spanning over three presidential administrations and nearly twenty years, mark extremely important turning points in modern history and have wittingly or unwittingly shaped American ideologies and worldviews irrevocably. Through the conduction of a narrative and close-textual analysis, the thesis project 
to follow will contextualize these speeches as they relate to the American people, American identity, and a larger campaign context. It is uncanny at best, and terrifying at worst, that these events recur in near perfect intervals of approximately eight years.

This will help form the synthesizing argument in the conclusion chapter, as I argue the reelection campaign component of these three similar events provide the necessary rationale for the analysis of their corresponding speeches. But first, I shall preview the upcoming chapters in this project. The literature review highlights very little research directly pertaining to these speeches, because next to no scholarship exists about them. Therefore, I connect other academic publications pertaining to the terrorists, the presidents' other speeches about the three terrorists, and wrap up the literature review chapter with a review of those few publications. Next, I formally justify the selection of these three speeches as the texts of analysis before transitioning to explain my methodological approach in the methods chapter. Each of the next three chapters will analyze the presidents' speeches independently. Finally, the concluding chapter will synthesize the preceding analyses and situate each one within the context of a continually extending political campaign cycle. 


\section{CHAPTER II: LITERATURE REVIEW}

Much scholarly attention has been paid to the rhetoric of American presidents. Thousands of reviews, studies, criticisms, and analyses of presidential speeches-from inaugural addresses to annual State of the Union speeches - stock the shelves and databases of libraries all around the country and world — and rightfully so. The utterances made by American presidents are powerful and have lasting impacts which should be studied. These speeches permanently alter the course of domestic and foreign policies, set agendas, frame crises, establish precedents, influence public opinion, and often dominate the air waves.

But why? Why, like moths to porch lights, are rhetoricians drawn to presidential speeches time and time again? Ultimately, it boils down to persuasion and the ways that rhetoric and persuasion are irrevocably intertwined. At its core, rhetoric is dependent upon the idea of persuasion. At least as far back as $335 \mathrm{BC}$, Aristotle defined rhetoric as the "power of discovering the means of persuasion in any given situation" (Aristotle, 1926, p. 1355). Moroever, even the word, rhetoric "derives from the ancient Greek rhetorike, meaning the 'art' (teckhne, or skill) of persuasive discourse undertaken by a rhetor (an orator or speaker)" (Burke, 1969, as cited in Martin, 2014, p. 2). Of the hundreds of differing definitions of rhetoric that have been produced and refined over the course of centuries and civilizations, there are two which inform my own perception of rhetoric. The first comes from Kuypers and King (2016) who, following a detailed retelling of its history in ancient applications, offer their own working definition of the term as "the strategic use of communication, oral or written, to achieve specifiable goals" (p. 10). Similarly, Gries (2015) suggests that a communication is only rhetorical if it has the "ability to induce change in thought, feeling, and action; organize and maintain collective formation; exert power, etc.; as it enters into relation with other things (human or nonhuman)" (p. 11). As an 
aspiring political speechwriter, I tend to view rhetoric from the perspective of the speaker. As such, I read between the lines of well-written speeches in search of goals fueling the speaker's word selection. The speech is intended to accomplish something, to reassert power or authority, to change something - even if that change is affected only in the minds and feelings of listeners.

With those definitions and understandings of rhetoric in mind, it is worth exploring how presidents may seek to persuade their audiences. As Hiland (2010) argues, "in a persuasive relationship, the power to act resides in the audience, and the speaker seeks to prompt the audience to action" (p. 57). This dynamic is complicated though, when institutional power, such as the power provided to the Executive Branch by the U.S. Constitution, is introduced into the persuasive relationship. This institutional power is always looming over presidential rhetoric and therefore remains relevant in all presidential speeches (Neustadt, 1990; Rubin, 2020).

That said, there is another actor to consider when evaluating presidential speeches. Certainly, the president is the speaker. His words should be attributed to him as such. However, more often than not - particularly when the speech carries a great deal of weight (such as an inaugural address, State of the Union speech, or a speech announcing the assassination of a foreign terrorist) - presidential speeches are penned by a speech writer or team of speech writers. From the desk (or desktop) of the speechwriter, draft after draft is often sent to the president for review, at which point presidents have been known to make editorial changes sometimes up until the final moment before the words of the speech leave the president's lips.

However, for the purposes of this essay, I will continue to attribute the words of presidential speeches to the president who uttered them. After all, even if speech writers are largely responsible for a particular address, the president has the final say over the content and can, and sometimes does, make editorial changes even while delivering the speech. My focus 
and the focus of the president's audience should not dwell on who wrote the specific verbiage of the speech, but rather on the implication of the words on the public and on a much larger scale, as they relate to matters of national security and foreign relations. Moreover, the president's tacit endorsement of a speech (implied by the sheer fact that he verbalizes the speech) constitues a rhetorical act contained within a rhetorical situation worthy of analysis.

Hiland goes on to suggest that in this unique relationship, the president (or presumed "author" of the speech) delivering persuasive rhetorical messages is empowered to compel his audience to act or react based on the message contained therein (Hiland, 2010). As such, it follows that presidents - with greater access to their audiences and the American electorate than ever before - rely "less on the more traditional means of persuasion, such as bargaining with Congress, and instead rely more on public approval and their public image" (McFarlane, 2016, p. 5). Of importance here is that the president's job security is, of course, dependent upon public approval and their willingness to vote for the president again in the event of a re-election campaign. The efficacy of the president's rhetoric also relies on public and constituent influence since a strong, popular president wields considerably more political capital than a relatively weak president.

If the president is in his second term, and/or does not intend to seek re-election, the future success of the president's political party's candidates is equally dependent upon the current president's rhetoric and overall favorability with the public. Accordingly, it should be noted that with the exception of the vice-president with whom the president shares the electoral ticket, the president is the only candidate for or against whom the entire nation can vote on Election Day. Maggio (2007) posits that this fact alone positions "the president's rhetoric, even if on a purely symbolic level, [as] extremely important to the polity" (p. 810). That polity then, today 
comprised of over 330 million Americans (United States Census Bureau, 2020), has a vested interest in the rhetoric of the president. The president's words and decisions not only directly impact their lives, but also provide or negate a return on their vote for or against the president. This sentiment is reflected by Medhurst (2008), who suggests that presidential rhetoric and the rhetorical presidency by association hold Americans accountable and responsible for governmental workings. In addition to voters' anticipated returns from their elected presidents and the impact of presidential rhetoric on their day-to-day lives, presidential rhetoric has the potential to shape the nature of the office held by the president (Hiland, 2010). In other words, the way a president communicates today in this term has the potential to change future expectations for presidents in future terms and administrations.

With this introduction to the American presidency as a rhetorical presidency, we should explore what scholars are disputing when they allude to a rhetorial or post-rhetorical presidency. For starters, some rhetoricians and scholars alike suggest that the American presidency has transitioned to a post-rhetorical state of being, though this is not a view that I share. As Hiland (2010) succinctly states, "the claim that the presidency has become 'post-rhetorical' is rooted in the notion that the presidency no longer operates through public persuasion, but rather through the strategic deployment of personal power held by the president" (p. 57). This perspective on the American presidency privileges a legalistic approach to power rather than a rhetorical approach, by focusing on powers and actions afforded to the Executive Branch by the U.S. Constitution rather than the power of words and actions communicated by the president's invididual rhetoric.

To be clear, this post-rhetorical position does not suggest that rhetoric plays no role in presidential politicking, but rather suggests that other aspects of presidential power are more 
persuasive and play a larger role in presidential accomplishments than rhetoric. That the president can affect change and exercise power through direct action means his rhetoric carries with it less significance for all involved parties (Howell, 2003). These other aspects of the presidency include, but are not limited to, executive orders, signing statements, and presidential policy directives - all of which Hiland (2010) analyzes in detail in his book. Through his analysis, Hiland reaches the conclusion that even when approaching documents like executive orders issued by presidents, a rhetorical analysis affords scholars a clearer understanding of presidential power than a legalistic approach alone. From the way these documents are written (and in some cases, delivered through formal readings by the president), rhetoricians can infer the way that presidents feel and want their constituents to feel about the matters about which these legal documents were written: "In the crafting and tailoring of [executive] orders [for example], the perception of the president strongly colors the meaning of the order" (Hiland, 2010, p. 160). The same reasoning should be applied to presidential speeches.

Thus, I favor the understanding of the American presidency which views it in terms of a rhetorically driven branch of American government, although I acquiesce that proponents of the post-rhetorical presidency are not entirely incorrect. They are justified in their arguments that presidential rhetoric has entered a new age following the election of George W. Bush and the events of September 11, 2001 (Hiland, 2010). Necessarily, impactful presidential rhetoric is often accompanied by direct action. In the cases of the three speeches analyzed in this essay, extremely important (yet largely overlooked) presidential communications were delivered directly following the capture or assassination of terrorists - and were directly ordered by and carried out upon the orders of the Commander-in-Chief. As such, the rhetorical presidency 
should be understood with the acknowledgement that presidential language is connected to action - and it is a way to compel the president's audience to act.

This is especially important right now, as we witness a trend in which presidential campaigns start sooner, last longer, and seemingly drag on forever. If a president, in his first term, decides to seek re-election for a second term, the campaign is likely to commence the moment the president makes his final decision. Election-related news seems to start sooner and sooner as well. Moreover, some scholars brazenly suggest that this is an intentional effort on behalf of presidents in the last few decades, their White House staffs, and their administrations overall (Alaimo, 2017; Blumenthal, 1982; Cook, 2002). Nowhere is the "forever campaign" more evident than within the Trump administration. As the gap between campaign rhetoric and presidential (governing) rhetoric closes, Tulis (1987) writes, "the overlap of the electoral campaign with the process of governing means that the distinction between campaigning and governing is being effaced" (p. 183). I include this seemingly tangential research to foreshadow the possibility that perhaps the Bush, Obama, and Trump administrations had some (insignificant though it may have been) political motivation behind capturing or assassinating the terrorists that so much of the nation identified as villains of the state. Pika, Maltese, and Rudalevige (2020) make the case for this line of reasoning when they defend the notion that every presidential action is motivated by some political calculus, though other motives may be more salient (Pika, Maltese, \& Rudalevige, 2020).

To this end, it is next to impossible to directly connect presidential rhetoric to an election outcome, just as it is impossible to prove that presidential rhetoric has ever changed individual votes (Edwards, 2003; Maggio, 2007; Zarefsky, 2004). But I would be remiss if I did not assume that the consideration of their own upcoming elections and re-election campaigns did not play 
any role in the construction and delivery of the speeches evaluated in this essay. Rather, as we will explore later, I anticipate discovering that the upcoming elections played a significant role in not only the way these speeches were written and delivered, but also in the decision-making process preceding the eventual order to capture or assassinate the three terrorists.

With all that in mind, it is worth noting that even though all this research exists, not nearly enough scholarly attention has been dedicated to the study of one type of presidential speech. The speech category in question was labeled epideictic (indicating a speech delivered to mark a special occasion) by Aristotle (1926). The focus of this thesis project contains only a few speeches - each of which was delivered by an American president following the assassination of a foreign terrorist by American military forces. Since the landmark event that was September 11, 2001, exactly three of these speeches have been delivered. The three speeches have been divided by remarkably consistent intervals, as approximately eight years passed between the delivery of each speech. This speech phenomenon warrants far more study than it has received thus far (which is, to say, scarcely any study at all). Milford (2016) expounds upon this observation in noting that "because of their rarity, research is surprisingly thin on military or terrorist crises" (p. 19). Though I disagree with Milford on the notion of "rarity"-after all there are now three identical instances of this speech situation that we can analyze - the majority of this chapter will therefore be dedicated to exploring the ways that scholars have examined other, similar presidential communications regarding terrorism and terrorists. To conclude this chapter, I will present the limited findings regarding the speeches in question.

\section{Presidents Define American Reality}

After establishing that presidents and their rhetoric are powerful, we can now move on to a review of scholars who research the ways that presidents are empowered to define and 
therefore shape or create social realities through their rhetoric. In accepting the assumption that social reality is fluid (and can be altered by external influence), we must also accept that presidential rhetoric has the potential to alter social reality (Maggio, 2007; Miroff, 2003; Rubenstein, 1989). As Zarefsky (2004) writes, "Because of his prominent political position and his access to the means of communication, the president, by defining a situation, might be able to shape the context in which events or proposals are viewed by the public" (p. 611). When electing presidents to office, the American electorate concedes some degree of power to the president, thereby allowing him to shape their collective social reality for them. By voting for the president, the American populace legitimizes his foreign policy and the way he shapes what is significant regarding U.S. international relations. In addition to the legitimacy granted to the president by means of electoral politics, the American electorate and public writ large also authorize "the president to seek declarations of war in times of attack, and to act in times of national crisis. Short of an attack," Farrell and Young (2003) write, "crises do not exist independent of public perception" (p. 720). Instead, crises are given meaning by presidential rhetoric, which in turn, helps to define social reality.

Without question, President Bush ascribed meaning to the crisis following the attacks of September 11, 2001. The American public needed no hand-holding or gentle guidance to understand that the nation was under attack. Rather, we watched the news in horror that day and in the days and weeks and months following that day. Our American psyche was permanently altered by the sight of not one or two, but three airplanes collliding with the side of skyscrapers and a military stronghold. We could not forget the sight of billowing smoke or the body count climbing (as bodies fell or were pulled unceremoniously from the wreckage) on the nightly 
news. In this instance, Bush did not need to define the crisis. It was defined for us by a terrorist attack.

In crisis events (as are most terrorist attacks), Americans look to the president and grant him the right to define our current state of emergency (Maggio, 2007). For the most part, we rely on the president's speech as truth, because we have been led in the past (though as usual, Trump is an exception here) to believe that the president has access to better, more accurate and more timely information than the general public about matters of national security. Given that presidents generally have access to better information, it seems reasonable for us to have faith that the president will act and communicate accordingly.

Regardless, we know that in these sorts of crisis-level events, presidents can command the news cycle and dominate political media by attempting to define social reality in times of crisis (Lockett et al., 2007). We know this to be true, but what are we to do with this knowledge? In answering this age-old question, Zarefsky (2004) identifies four main strategies by which presidents are able to shape the definition of social reality. First, he describes association, or the process by which rhetors connect two concepts together. Maggio (2007) offers, as an example, Bush's linkage of the attacks of September 11, 2001 and Bush's definition of those attacks as an "act of war" in subsequent speeches. Inversely, the second strategy by which presidents shape social reality is through disassociation, or the intentional breaking apart of two concepts which were once associated with one another. In the third strategy, condensation symbols are especially helpful in defining unclear or "ambiguous" situations, because they enable rhetors to "“condense' a host of different meanings and connotations that might otherwise diverge" into one meaning without the necessity of a clear referent to which a meaning might be ascribed (Zarefsky, 2004, p. 613). Simply put, presidents define social reality and formulate a means of action by taking 
ambigous language and ideas and tying them to a traditional metaphor-condensing the abstract idea to vivid metaphors permits the president, then, to craft a very specific meaning to reinforce his agenda. Lastly, frame shifting allows speakers to retroactively shift the context of a debate. Once again, Maggio points to Bush's rhetoric as evidence of this strategy, as his "rationale for the invasion of Iraq shifted from weapons of mass destruction to 'spreading democracy"' (Maggio, 2007, p. 814; see also Bush, 2002; Bush, 2003; Sanger \& Shanker, 2003). Although Bush's defense of the Iraq War will not be explored much further in this essay, it is interesting to see how other scholars have analyzed his justification of the war. It will prove especially interesting when we can apply a similar analysis to the justification behind these three presidents' assassinations of terrorists — and how they retroactively and strategically defend their and their administrations' actions.

\section{American-isms}

Presidential rhetoric has long been tagged with a tendency to fall back on a number of "-isms" that can tangentially, because of the context in which they help describe foreign policy, then be labeled "American-isms"_ or the -isms that function as nouns occuring in the American presidential context. These include American exceptionalism, exemplarism, and interventionism. My reviews of these -isms are not meant to pass any judgment on the use of or reliance on any of these tendencies. Rather, it is important to acknowledge their frequent use in presidential rhetoric, as noted by many rhetoricians before me. Moreover, their usage helps to establish a framework for understanding American identity. We need to understand how they have been used and understood in the past, so that we have strong foundations upon which to build an analysis and criticism moving forward. 


\section{American Exceptionalism}

It was onboard the flagship, The Arbella, that John Winthrop made his iconic declaration: "For wee [sic] must consider that wee [sic] shall be as a citty [sic] upon a hill. The eies [sic] of all people are upon us" (Winthrop, 1630, para. 1). It is in this very sentiment that the stillprevailing concept of American exceptionalism has its roots. When I discuss American exceptionalism in this context, I refer to the definition presented best by Madsen (1998) who writes, "exceptionalism [is] the notion that Americans have a distinct and special destiny different from that of other nations" (Madsen, 1998, p. 1). It is the prevailing idea that America and Americans are chosen by some higher power, set on a high pedestal for the rest of the world to see - a gleaming example of how governance and democracy should work (Stramer, 2020). It is the notion that "America is not the problem, it is the solution, and if America is not the solution, there will simply be no solution" (Hongju Koh, 2003, p. 1490).

Edwards (2018) identifies three ways in which Americans adhere to the ideal that the United States is a chosen nation. First, citizens believe that our nation is equipped with a special destiny after which nations around the world will want to model for their own homelands. Second, proponents of American exceptionalism tout the U.S. Constitution as a governing document that inherently sets us apart from European or "Old World" countries, because our government was built upon "ideas, values, and principles" of freedom unlike legislation in other parts of the world. Finally, and most importantly, the belief that the United States is a nation chosen by and protected by God requires citizens to embrace that the United States is unique as it occupies a special status with the Almighty. Here, the belief is strengthened by the idea that America is exceptional "not for what it is, but what it could be" (Edwards, 2018, p. 177). 


\section{American Exemplarism}

Not unlike American exceptionalism, exemplarism is rooted in the idea that the United States should be viewed as a model of political possibility. However, exemplarism goes one step further than exceptionalism, because as its name suggests, American exemplarism identifies the United States as a shining example. The nation is the A+ student in a classroom full of failing and subpar student nation-states. It is the country with its hands up in the air, waving and pleading, "hey, call on me, I have the best ideas." Edwards (2018) identifies the incorporation of diverse peoples into American society, the ongoing endeavor for increased civil rights, and the mission to strive for financial prosperity and success (flawed though the American dream may be) as just a few of the ways that America could be seen as the modern prototype after which other nations should construct their societies.

I contend that at no time in our history were the ideals of American exceptionalism and exemplarism more prevalent than in the aftermath of the attacks of September 11, 2001. As Milford (2016) suggests, the structure of American exceptionalism made those terrorist attacks all the more devastating (p. 25). After all, how could our nation, our people be attacked when we are supposed to have the Almighty on our side? It seemingly defies all logic and fundamentally undermines one of the tenets of exceptionalism: "What, then, shall we say in response to these things? If God is for us, who can be against us?" (Holy Bible, New International Version, 1984, Romans 8:31). In addition to that crippling overwhelm experienced by Americans across the board, as many struggled to come to terms with the fact that their "chosen" and perfect country was under attack, American exceptionalism and exemplarism meant that the effects of those terrorist attacks lasted longer than they otherwise might have. However, one might argue, this justified the much-delayed responses to terrorism and perceived terrorist activity on behalf of 
Presidents Bush, Obama, and (to a lesser extent, through several degrees of separation from the attacks of September 11, 2001) Trump.

\section{American Interventionism}

It is impossible to discuss exceptionalism and exemplarism without also paying attention to American interventionism, or the belief that the United States should satisfy the expectations of these ideals by intervening into foreign affairs - as the role model it is. That said, American interventionism does not stop at simply meddling into foreign affairs. Instead, interventionism

provides justification for interjection into "all spheres of political, social, economic, and cultural life... The United States' 'special role' is to be the global leader in moving the world toward greater democracy, freedom, human rights, free markets, etc., while also defending those nations that subscribe to similar ideals" (Edwards, 2018, p. 178). Presidents and citizens alike have embraced this identity and "special role," proudly boasting our status as a "de facto leader of the world and the primary architect of the liberal international order" on our puffed chests, as if this honor was a medal awarded to us on a global stage (Edwards, 2018, p. 180).

This desire to intervene has manifested itself in many ways throughout American history. But it was especially prevelant following the attacks of September 11, 2001. As we will discuss in greater detail later, this was extremely apparent in the presidential dilineation between "us" and "them," "heroes" versus "villains," and generally in the way that (foreign or domestic) innocence was discussed and incorporated into presidential speeches regarding terrorism. Regardless, interventionism as it is discussed here cannot stand alone without the structural support of both exceptionalism and exemplarism. And many scholars explored how the three are related. In his analysis of presidential rhetoric after 9/11, Killian (2008) identifies three recurring themes, all related to exceptionalism, exemplarism, and interventionism: "the United States as 
the benevolent hegemon, the United States as an exceptional experiment with a divine role, and the United State[s] as the antidote to a new and elusive enemy" (Killian, 2008, p. 7). Similarly, presidents intertwine these concepts in their presidential rhetoric, and have been known to do so for the better part of the last seventy five years.

Recently, this was true of both the Bush and Obama administrations. In discussing America's role in the international order, their administrations and their rhetorics respectively indicated an obligation to serve as a leader among other nations. Trump's rhetoric takes a different turn. As a candidate, his "America first" mentality won the hearts and minds of millions of voters. And as president, Trump's rhetoric “suggested this global leadership mission was over... His administration would redefine U.S. global engagement for the $21^{\text {st }}$ century” (Edwards, 2018, p. 181). It is evident that these three themes (or -isms) plainly recur throughout presidential rhetoric. Accordingly, American exceptionalism, exemplarism, and interventionalism will no doubt make appearances throughout the three speeches I will examine from Bush, Obama, and Trump.

\section{Rhetoric of Innocence}

Before seguing into a discussion of vilification and an "us" versus "them" dichotomous split, let us return to my own remembrance of 9/11. Aside from an adrenaline-laced memory of panging fear (for my uncle, for my family, and for those affected) on September 11, 2001, the clearest memory I have from that fateful day is the resounding phrase, "but we didn't do anything wrong." I said those words time and time again as my young mind tried to process why anyone would want to hurt us - why, moreover, would anyone want to hurt Americans?

Weren't we supposed to be the good guys? Captain America was a good guy. We are always the good guys in movies... right? 
I was far from the only American questioning the motives of terrorists. My childlike panic echoed around a room of millions of Americans questioning the very same concepts of innocence and guilt. And my concern was reflected by much of the rhetoric pushed out by President Bush, who capitalized upon the rhetoric of American innocence in much of his rhetoric in the aftermath of the attacks. His portrayal of American citizens and the recipients of such catastrophic hatred writ large as innocent should come as no surprise, especially given the foundations of reality established with American exceptionalism, exemplarism, and interventionism. When we position ourselves as evidence of perfection, we simultaneously position ourselves as above reproach. We - as Americans — are impervious to threats and untouchable by any and all ill-will. When confronted by an opposing force like that of a terrorist organization, however, it is easy to imagine that Americans would readily assume the position of the innocent.

Makstenieks (2007) explains that it is extremely challenging to separate the innocent in these scenarios from the terrorist Other. Rather, "terrorism and the innocent are almost inextricably merged; victims and victimizers are paired in almost every facet of the rhetorical landscape, constructing a mutual genesis and perpetuation" (Makstenieks, 2007, p. 4). There would simply not be a need to distinguish innocents from the group if there was not first an attack or at least the threat of an attack to set apart innocents or victims. But in separating innocents from the rest, it should be noted that the only victims of terrorism are not the direct victims of the terrorist attacks — though those individuals are victimized, without question. Rather, the definition of and reference to innocents or "innocence" in presidential rhetoric (especially) must be expanded to include not only those victims who were directly hurt or lost their lives in the attacks, but also to the family and friends of those victims, the potential victims 
of future terrorist attacks whom soldiers swore to protect in the wars following the attacks of September, 11, 2001, Muslims and Arabs living in the United States who were deemed guilty by association and therefore discriminated against despite their innocence, and the people untethered to terrorist ideology or organizations who were unfortunate enough to live in Iraq or Afghanistan as the War on Terror erupted around them (Makstenieks, 2007).

Importantly, as we discuss innocence, we generally do so without much regard for reflexivity—for why or how we reached the conclusion that the party we deem "innocent" is, in fact, innocent (Makstenieks, 2007). Without noticing, this judgment call is often accompanied by the gendered demotion of women as weak, in so far as women and children are immediately classified as "innocents." They are the first ones ushered off ships in the event of a shipwreck. They are the innocent civilians hurt in battle — because women and children seemingly should not have stepped foot on the battlefield in the first place. Makstenieks (2007) rationalizes that these classifications of women (and to a lesser degree, children) as innocent is an indication by the rhetoric of innocence (and its users) that women are inherently in need of protection and irrevocably set apart from men as part of the general populace. Moreover, the entire idea of "protecting" or ensuring that something is "safe" is also gendered. While women are the "innocent victims," men are the ones protecting them. Therefore, women are the damsels in distress in not only these narratives, but in countless fairy tales throughout human history. Men are the heroes atop white horses upon whom the burden falls to save the day. This is a seemingly natural extension of a political system that prioritizes masculinity as a natural component of hegemony, especially since this logic of innocence is largely unquestioned, thereby bolstering an already entrenched common sense, or the acceptance of unquestioned beliefs (Gramsci, 1971). To add insult to injury, though, this tradition rooted in hegemonic expectations also allows for 
the continued emergence of the existing hegemon (in this case, the United States) to determine which parties are innocent.

\section{Us Against the World: Dualism and the Vilification of Terrorists}

Regardless of who is deemed innocent in presidential rhetoric, the inclusion of the idea of innocence effectively requires the presence of an oppositional force. Something or someone must attack or harm the innocent in order to make them an innocent or a victim in the first place. Herein lies the dualist "us" versus "them" dichotomy we see so often in presidential rhetoric.

\section{Dualism: An "Us" versus "Them" Dichotomy}

This dichotomy is not a new phenomenon in presidential rhetoric regarding terrorism. Rather, the pitting of parties against one another-wherein we (Americans, with our perfect examples of democracy and governance) are on the side of the right and righteous and they are out to get/hurt/harm us and our way of life - is a trend common in many foreign affairs dealings from the Revolutionary War to the Cold War. Most recently, this has been pointed to as a trend throughout nearly all of Trump's campaign rhetoric - extending well into his tenure as president. Notably, his favored "us" versus "them" rhetoric occupied its own designated portion of his inaugural address, and even served to position Americans against one another- "they" no longer must hail from beyond our nation's borders. Rather, Trump identifies Americans as separate and apart from his supporters when he refers to "us" or "we." Despite the surface-level incorporation of all Americans, his pronouns can and have been interpreted to refer only to people who agree with him and his ideology. He excludes American citizens from the collective "us" in the same way that presidents before him have excluded foreigners and international actors from the American "us." "They" simply have to disagree with "us" on an ideological basis to be cast aside and deemed less than or somehow "evil" (a concept into which we will delve shortly). 
This concept was reintroduced with a new fervor and tenacity following the attacks of September 11, 2001. Given the existence of innocence rhetoric and overwhelming national adherence to the ideals of American exceptionalism and exemplarism, it only follows that in priding ourselves on our innocence (as we perceive it), we would accordingly identify our attackers as a foreign "them" set on deliberately causing "us" harm.

Immediately following the attacks, Bush went quickly to work, contrasting the "evil" tendencies of our attackers with the observed goodness and pureness of American victims who came together in support of one another in our darkest days (Abdelaal et al., 2015). We desperately needed an outlet for our hurt, and we found it with our president's help. In identifying the hijackers as evil terrorists (not to mention lumping anyone who supported or harbored the individuals responsible for committing such heinous acts against humanity as evil terrorists by association), President Bush aided the American people's search for a guilty party (Brydon, 2004). President Bush gave us a "them" to whom we could attribute blame. In granting us the permission we needed to cast blame, this dichotomy also helped justify the sense of bloodlust bubbling to a boiling point in many Americans.

To that end, Lee (2017) writes, "this clunky dichotomy—us, the Christian West, and them, the Muslim and Arab world - the former civil, the latter barbaric, was more than the basis of popular stereotypes. It justified imperialism" (p. 4). Once more, we have spun around the revolving door of American exceptionalism, exemplarism, and interventionism, as imperialism is just an extension of interventionism which deals specifically with military force and diplomacy abroad. So the "us" versus "them" relationship promoted by the Executive Branch in the aftermath of 9/11 allowed Americans to go down a path toward war. However, before we move onto a discussion of recurring pronoun usage in this dichotomous presentation of good and evil, 
"us" and "them," we must return to Lee's point. In addition to the black and white argument of civility against barbarism, there exists a murky gray area in which religion becomes manifest.

Years ago, Bush laid the groundwork for our current president's Islamaphobic and antiOther rhetoric (Rubin, 2020), when he returned to what Brydon (2004) calls a "prophetic argument, last found in the Cold War era, when America was challenged by 'godless communism"” (p. 3). Relatedly, Wander (1997) wrote about such Cold War rhetoric that, One side acts in accord with all that is good, decent, and at one with God's will. The other acts in direct opposition. Conflict between them is resolved only through the total victory of one side over the other. Since no guarantee exists that goodwill triumphs, there is no middle ground (p. 157).

Here, Wander suggests that when matters of God are called into question — even as they were decades prior to the attacks of $9 / 11$ - the gray area of religion is seamlessly understood as a black and white issue for Americans. There is either the side of the righteous and religious worshipping of a Christian God or the other side. It is plain and simple, although we know that in reality, these issues are rarely as simple as they seem in a moral and ideological context.

Unlike the circumstances of the Cold War era, America's new enemy was one that selfproclaimed to be motivated by an extremist interpretation of the Quran. The same hijackers who inflicted death and destruction upon the United States did so in the name of God. Recall that one tenet of exceptionalism is the belief that the United States is exceptional among other nations because it is chosen and protected by the Christian God. With that in mind, the presentation of terrorism committed to please or praise Allah understandably rattled many Americans who believed wholeheartedly in American exceptionalism. When both sides claim to have divine backing and justification for their actions, one must be incorrect. Their mutual exclusivity 
requires a Western leader - in this case, the president - to find ways to differentiate our godly mandate from the Other's so-called heretical and inferior warped sense of reasoning.

However, this rattling realization extended beyond shock. And while it might stand to reason that we should have realized before that God could exist as a rationale on both opposing sides of political or religious conflict - thereby warding off the usage of loaded terms like "evil" (Hariman, 2003) — that is far from what happened. Rather, Bush capitalized upon this comparison by incorporating religious dualism into much of his rhetoric following the attacks of September 11. Specifically, Bush repeately presents two opposing actors, "with the enemy viewed as having misused its religious tradition, while the United States was fulfilling its mission" (Brydon, 2004, p. 2). Even this comparison between "us" and "them" reinforced the presentation of terrorism as an example of moral turpitude and religious inferiority contrasted with the exceptional moral superiority of the United States.

While on the subject of "us" in the "us" versus "them" dichotomy, it is worth including here that the use of pluralized pronouns in presidential speech helps to create unity among certain audience members and the American citizenry. By repeating "us" and "we" in their speeches that pertained to terrorism and terrorist attacks, Presidents Bush and Obama include Americans writ large in their feelings and sense of responsibility (Abdelaal et al., 2015). Although there is not nearly enough published work from which to glean concensus on the matter, it is largely accepted that these pluralized pronouns help Americans, who might otherwise feel weak in the seemingly never-ending fight against a big and bad terrorist Other, to feel empowered. Especially after the capture or assassination of a leader from the Othered group, these plural pronouns, "us" and "we," help to make Americans feel as though they held some 
shred of responsibility in taking down a piece of the "them" that threatens our sense of security (Abdelaal et al., 2015).

\section{Unconscionable "Evil"}

As Hariman (2003) points out, public discourse and speeches from recognized politicians are riddled with both euphemism and exaggeration - literary devices that make acceptable the labeling of another person or group as "evil" without much consideration. Its usage might even be justified as intentional rhetoric meant to perform well in what Hariman (2003) calls a "sound bite society" (p. 512). While at the drawing board, speech writers might even defend their decision to call terrorists "evil" with a few basic rhetorical questions: What harm is there in oversimplifying something as complex as terrorism or a fundamentalist terrorist? Are we not doing the American people a service by giving them a clear target to blame? However, this judgment-laden adjective and label seep into public perception and make it challenging to separate the person or group from the label. Therefore, the utilization of such terminology in public speech, especially from behind a podium demarcated by the seal of the president, warrant further exploration and analysis.

Before long, another comparison emerged. Just over a month removed from September 11, 2001, National Security Adviser Condoleezza Rice began to link Saddam Hussein (a terrorist later proven to have no connection to 9/11) to Adolf Hitler, a comparison that left no room for questioning (Farrell \& Young, 2003). This comparison clearly communicated to the American

people that Hussein was unquestionably an evil and immoral man - the first through-and-through villain of the twenty-first century. It was unimportant to Americans that Hussein did not have any ties to the attacks still fresh in their memories. For reference, "A Washington Post poll in late summer 2003 showed that seven in ten Americans believed [Hussein] had a role in the 
September 11 attacks, and 80\% thought it likely that he had helped al Qaeda" (Lockett et al., 2007, p. 212). This belief and perception of Hussein as a villain who should be feared carried over into pop culture references and even into children's impressions of horror:

What does it say about America when the biggest seller at Halloween is the Saddam Hussein costume? What does it say when Saddam Hussein's visage appears on dart boards in taverns, or when the American entrepreneurial spirit is manifested in a new line of Saddam Hussein "voodoo dolls"—dolls which, by the way, sold like hotcakes? (Hogan, 1995, p. 498)

Importantly, the connection between Hussein and Hitler was, like most references in American history, not a new one. Rather, as one might note in the quotation above, Hussein was a common figure in American politics and many American conversations surrounding terrorism. But these impressions leftover from past administrations and previous comparisons between a recognized terrorist and one of the agreed-upon worst people to have walked this earth helped to build consensus that Hussein was "evil." This categorization was easy to translate to subsequent terrorists as names like Osama bin Laden and Qasem Soleimani emerged. The judgment calls only became easier to make, the labels became easier to place permanently.

Americans developed "evil" into a kind of short hand to help in the processing of insurmountable terror. For example, Popp and Mendelson (2010) conducted a study of several covers of Time Magazine that made good use of a similar short hand to clearly communicate "evil." Their strategy was to place a big red "X" over the faces of confirmed terrorists who had either been captured or killed — even though the "X-ing out" of villains found its origins in a May 1945 edition of Time Magazine marking the death of Hitler. The red symbol sent a clear message then, just as it did when later it was laid over the black and white faces of Saddam Hussein and 
another Iraq War insurgent, Abu Musab al-Zarqawi (Popp \& Mendelson, 2010). Of relevance to this project, Time Magazine resurrected the by now well-codified symbol once more after the Obama administration successfully assassinated Osama bin Laden in 2011 (Rothman, 2017). Without requiring any further explanation, American readers could breathe a sigh of relief after absorbing and processing that cover: America had vanquished yet another "evil" threat. I have dedicated so much of this chapter to a discussion of "evil" and the vilification of the world's bad guys because this rhetoric remains today—barely disguised as foreign policy within the Trump administration. Fowler (2019), in fact, accuses Trump of using rhetoric reminiscent of Cold War rhetoric, when he discusses such matters ranging from Iran to ISIS/ISIL to the Syrian Civil War. Regarding each of these groups, Trump identifies "barbaric criminals who seek to obliterate human life" (Trump, 2017, para. 21) and communicates to his audience that our great and exceptional and interventionist nation was "locked in a battle between good and evil" (Fowler, 2019). He even says the word, "evil," when describing these "barbaric criminals," thus leaving no room for his audience to question their morality. They-like Hitler and Hussein—are villains, through and through.

\section{Presidential Paternalism: Only I Can Protect You}

So the bad guys went bump in the night. The bogeyman is awake and active beneath the bed. My nightlight is not enough to protect me in this moment of sheer terror. Where do I run? The clear answer is that I will find much-needed comfort and consolation down the hall in my parent's room. Surely, they will know what to do.

On a larger (and significantly more frightening) scale, the terrorists wreaked havoc in New York City, Washington, D.C., and Pennsylvania. Their threats arrived anew with each passing day—or so we were led to believe by the daily threat level updates on the nightly news. 
But this time, we could not run to our parents' rooms (although I will admit that as a child afraid of the bogeymen shaped like Hussein and bin Laden, I ran the few steps down the hall on more than a few occasions). Our parents surely were not qualified in this arena-nor did they have the resources necessary to quash this particular threat. The only place left to turn was to the presidency. And the president was seemingly up for the challenge. In fact, the rhetoric of paternalism actually played in his favor as the Bush administration worked around the clock to redefine our social reality and craft foreign policy in response to terrorist activity.

At its core, paternalism "refers to 'government as by a benign parent"” (Blackburn, 2008; Thomas \& Buckmaster, 2010). In this presumed parent-child relationship, several assumptions are made. The first and arguably most important of those assumptions is that "those in positions of power have... the right and the obligation to overrule the preferences of those deemed incapable of knowing their true interests" (Thomas \& Buckmaster, 2010, para. 10; See also: Childers, 2007). As it pertains to terrorism after the attacks of September 11, 2001, the president and his administration assumed the role of the nation's paternal caretakers.

If Bitzer can define "public knowledge" as "a complex of persons, events, objects, and relations presenting an actual or potential exigence which can be completely or partially removed if discourse introduced into the situation can so constrain human decision or action as to bring about the significant modification of the "exigence"” (Bitzer, 1968, p. 6), we can definitively say there was little to no public knowledge about governing decisions or policy responses pertaining to terrorism after 9/11. Farrell and Young (2003) make this case about the Bush administration. And I extend their conclusions to include information surrounding the capture of Hussein, as no one knew (for national security reasons) the mission had been executed or ordered until well after its completion. But after the Obama administration assassinated Osama bin Laden, people 
were left with more questions than they had before his death-because again, this was a covert operation. We did not know it was coming, and so we could not prepare for the news' arrival ahead of time. Many Americans did not truly believe bin Laden to be dead. Without a body or evidence, many felt the whole ordeal smelled a bit fishy. Later, the assassination of Soleimani left many Americans questioning American involvement in the first place. The largely unheard of (by largely isolated and insulated Americans) Iranian general had not crossed our radar as a threat, and as no evidence emerged in the days and weeks following his murder, we began to question whether he really posed a threat at all.

In each of these situations, the rhetorical situation created by terrorist attacks (whether past or predicted) and a distinct lack of information available to the public made it extremely difficult for Americans to question the president's paternal actions (Farrell \& Young, 2003). In conclusion, following the attacks of September 11, 2001, President Bush could hardly hope to ignore or exclude that citizenry which earned him his seat in the Oval Office just one year prior. But through the strategic occlusion of information surrounding the attacks, he and his administration proved quite successful at keeping Americans in the dark, so that the Executive Branch could carry out their goals and advance their proposed War on Terror unhindered by the burden of accountability (Childers, 2007).

\section{President George W. Bush (2001-2008)}

Just shy of one year into his first term as president, George W. Bush was whisked from an elementary school classroom in Florida and ushered onto Air Force One by Secret Service agents for his safekeeping. His safety was, of course, a matter of utmost importance as all accounts indicated the United States was under attack by terrorists. As September 11, 2001 unfolded, people all around the world watched with bated breath as multiple planes collided and 
the body count soared. This could hardly have been how Bush anticipated his day to proceed. Similarly, there was no way he or his administration could have predicted this sharp turn in their plans for the presidency.

Nevertheless, the attacks of September 11, 2001 threw a wrench in politicking and business as usual in the White House. After the attacks, the vast majority of Bush's public speech necessarily revolved around terrorism and terrorist threats. Directly following the attacks, Bush made a series of addresses that would instrumentally shape presidential rhetoric regarding terrorism for at least the next three presidencies. As has already been addressed in this chapter, one of the clearest themes to emerge from this time was Bush's view on terrorism as an issue best boiled down to a good and righteous "us" pitted against an immoral and unconscionably evil “them" (Rubin, 2020). The theme was reflected in Bush's now-famous line "you are either with us or against us" anti-terrorism campaign, variations of which include "with the terrorists" in place of "against us" (Bush, 2001). This expanded theme smoothly translated into an aforementioned spike in the number of hate crimes against Muslim Americans, by making many of the world's and the country's Muslims into easily-identifiable targets by already-scared Americans (Rubin, 2020).

A common theme in existing scholarship about Bush's response to 9/11 emerged throughout my research in which President Bush unapologetically relied on the old American shorthand of exceptionalism, exemplarism, and interventionism to communicate to citizens that it was the nation's “divine mission to defeat global terror” (Killian, 2008, p. 18). He presented a version of the truth that corresponded to Wander's (1997) understanding of dualism, in which no middle ground between "us" and "them" could possibly exist. Rather, Bush presented the attacks of September 11, 2001 as actions that carved a clear division between the United States and its 
terrorist enemies - not to mention the rest of the world (Bostdorff, 2003; Childers, 2007; Murphy, 2003).

As we have already explored and will continue to explore in much greater detail later, one of those terrorist enemies for the Bush administration was Saddam Hussein. Although Osama bin Laden was the true mastermind responsible for orchestrating the attacks of 9/11, he effectively eluded American operatives for years. In the interim between September 11, 2001 and bin Laden's eventual assassination under the Obama administration, Bush and his administration painted Hussein as the target of American hatred and "evil" labeling. Publically, Bush's rhetoric successfully tied Hussein to bin Laden, despite the fact that no evidence has yet to emerge showing the two coordinating in any capacity (Rubin, 2020). Moreover, to mark the one-year anniversary of 9/11, Bush made the connection directly, identifying Hussein as a serious threat to the nation, effectively extending the original terrorist attacks to his administration's proposed War on Terror, perhaps for personal political gain as the nation was preparing for the Iraq War (Hiland, 2010; Lockett et al., 2007).

In vilifying not only the terrorists responsible for the $9 / 11$ attacks, but also their associated organizations and some unassociated terrorists (like Hussein), Bush presents Americans as default heroes. Lee (2017) even goes so far as to compare Bush's United States to Superman, "[donning] the hero's cape and [flying] forth from the phone booth" to bring the American ideals of freedom and liberty to the democracy-starved world (Lee, 2017, p. 6). Oddo (2014) further explores the theme of American heroism when he applied a critical intertextual analysis to speeches about terrorism from both Bush and Obama. Oddo concludes that both presidents consistently referred to American actions as positive and emblematic of heroism in the face of terrorism. In the Bush and Obama speeches, American heroes were clearly identified, but 
neither president presented the terrorist enemies as concrete people. Rather, terrorists were characterized as "negatively moralized abstractions" (Oddo, 2014, p. 528). Ultimately, Oddo concludes that Obama relied on these presentations with greater frequency than Bush, thereby staying true to the message of a hopeful and heroic future (Oddo, 2014).

\section{President Barack Obama (2009-2016)}

I present Oddo's (2014) analysis as an introduction into this subsection on Barack Obama's rhetoric on terrorism because Oddo is far from alone in his conclusion that the rhetoric of these two presidents were strikingly similar, even outside my limited scope of the speeches addressed after the elimination of a Middle Eastern terrorist threat. Although Obama delivered significantly fewer speeches than Bush on the subject of terrorism (Rubin, 2020), the two presidents' actions against terrorists were equally similar. In fact, the Obama administration not only continued many of Bush's anti-terrorism policies, Obama may even have been more aggressive, at least with its drone strikes against terrorists (Rubin, 2020). Regardless, the main difference between the first two presidents in office after September 11, 2001 is that Obama strived throughout his presidential campaign to change the American approach to terrorism. He aimed to "downplay rather than ratchet up the terror threat" (Rubin, 2020, p. 116). As his tenure in office progressed, therefore, Obama transitioned to a rhetorical approach in which he identified terrorist actors and their affiliated organizations by name, rather than relying on quick morally-loaded shorthand terms like "evil" or "barbaric" (Rubin, 2020, p. 108). These rhetorical changes went a long way toward assuaging the public's fears regarding terrorism. Because even though Americans were seven years removed from the immediate horror of September 11, even the mention of terrorism or terrorists involuntary evokes an emotional response (Eiholm Kjær, 2020). 
In addition to changing the way he addressed the public regarding matters of terrorism, another significant difference separates his rhetoric from his successor, in so far as the American people were given at least a modicum of forewarning that the assassination of bin Laden was on Obama's agenda (Holland, 2007; McFarlane, 2016; Schmidle, 2011). Therefore, it should have come as no surprise to Americans that Obama and his administration pursued bin Laden. In fact, his desire to do so was transparent enough that voters cast their ballots on Election Day in 2008 knowing (or at least having had access to proof) that Obama had placed a target upon bin Laden's back.

The Obama White House photographer Pete Souza captured a photo of the Situation Room the night bin Laden was assassinated, thereby inviting scholars to conduct analyses of visual rhetoric throughout the evening (Souza, 2011). As McFarlane (2016) points out, Obama's speech that night was important on its own, but the Souza photo communicated a great deal to the American public. McFarlane's (2016) analysis of the image reveals a presidential poise unlike that which we generally expect from presidents. Obama is not the central focus of the image. Instead, he is leaning forward and seemingly "passive" in the photograph, leaving viewers to "[fill] in the "enthymematic gaps." As a result, she argues that Obama is made both more personable and heroic to viewers of the image (McFarlane, 2016, p. 10).

\section{President Donald Trump (2017-2020)}

Unlike Obama, Donald Trump vowed to return America to its exceptional roots throughout his campaign with a focus on "America first" and into the infancy of his presidency as this too received considerable coverage in his inaugural address (Edwards, 2018). His commitment to American exceptionalism placed renewed distrust in many Americans, particularly members of his base, regarding anyone perceived as Other. Certainly, Othered 
individuals included many of the same citizens targeted back in the Bush administration as potential terrorists (Rubin, 2020). But Trump deepened this distrust of other, namely minority identities by connecting terrorism to immigration through his rhetoric (Rubin, 2020). Still today, if he is not linking the groups together through shared negative attributes, then Trump is combining the two groups as "threats" to the exceptional American way of life (Rubin, 2020).

Despite the swing toward specificity under the Obama administration, Trump has reverted back to Bush's rhetorical patterns of identifying terrorists and does not prioritize specificity when talking about these threats. Rubin (2020) found that Trump was most likely to call these Othered threats "radical Islamic terrorists," "evil-doers," or to connect them to wellknown immigrant gangs like MS-13. Also of note in Rubin's analysis is Trump's return to the moral label, "evil," in connection with a religious identity in "radical Islamic terrorists." There is no doubt that Trump has also fallen back by articulating a dualist division with his rhetoric relating to terrorism, thereby deepening the divide between "us" and "them" and further concretizing his view of social reality which is dependent upon division. It also worked to deepen the divide between American citizens here at home, where "us" was safe and righteous, but anyone that looked like a terrorist "them" was dangerous. To elaborate, Rubin (2020) writes about Trump's rhetoric: "It vilifies a vulnerable minority in America and plays into the worst stereotypes of the Muslim world. And it does all this in the wake of no great terrorist threatISIS was already on the wane when Trump took office" (p. 154). Trump did not seem to mind that the threat of terrorism was dwindling in the minds of the American people. Instead, he took advantage of the anti-Other rhetorical groundwork laid by Bush immediately following the attacks of September 11, 2001 to clarify his divisive rhetoric that works so hard to separate "us" from "them." 
At the time of this writing, nearly two decades have elapsed without another major attack like the ones we saw on September 11, 2001. The threat of large-scale terrorism, if it exists at all, no longer occupies the forefronts of most of our minds. Yet even with this understanding, Trump identified Soleimani as a "terrorist ringleader," claimed he was plotting some evil terrorist act against the United States, and Trump vowed that Soleimani will meet his demise (Rubin, 2020). With that, we need to explore the few existing studies that examine Trump's rhetoric in the announcement of Soleimani's assassination.

As arguably the most controversial of the three post-9/11 presidents, there have been a few studies published about Donald Trump's speeches announcing the assassination of Major General Qasem Soleimani. Interestingly, each of these three studies evaluate how Trump justifies the killing of Soleimani, a man with whom many (if not most) Americans were entirely unfamiliar before news broke of his death. Talmon and Heipertz (2020) went a step beyond weighing Trump's justification for Soleimani's assassination to contemplate the legality of the assassination of Soleimani. Ultimately, they concluded that it was, in fact, legal according to international humanitarian law: "General Soleimani was the military commander of the Quds Force, an official branch of the regular armed forces of Iran. As a member of the Iranian armed forces, he qualified as an enemy combatant... Enemy combatants may legitimately be attack[ed] as 'military objectives' irrespective of whether their killing offers a definite military advantage" (Talmon \& Heipertz, 2020, p. 12; Office of the High Commissioner, 1977). However, while this may provide a legal justification for murdering Soleimani, it certainly does not address the ethical-rhetorical and moral rationale. As such, these studies help undergird the foundation for this thesis - that the rhetorical framing of terrorism itself as well as its discursive implications 
reveals the need for a rhetorical analysis of presidential discourse concerning the three assassinations in question.

Although they argue the Trump administration's actions against Soleimani were legal, Talmon and Heipertz (2020) make clear that their conclusion rests on the information presented by Trump in his speech. The information presented in that speech was quite vague and little to no information regarding the operation was released after Soleimani's death. Therefore, and given Trump's past flirtations with falsehoods and favor for untruths (Kessler et al., 2020), the accuracy and legitimacy of Trump's statement are called into question. As a result, it is impossible to reach a formal, legal conclusion regarding Soleimani’s assassination.

On the subject of minimal transparency, Mandarani and Fakhruddin (2020) touch on presidential paternalism from Trump following the assassination of Soleimani. Their essay, a critical discourse analysis that examines the exercise of social power (and its potential abuse) within Trump's speech, focuses on the ways that Trump reasserted his position and paternal authority as president. According to their analysis, Trump "emphasized his stance as [a] president who must protect his people from the evilness carried out by [Soleimani]" (Mandarani \& Fakhruddin, 2020, p. 134). Trump's desire to protect Americans stems directly from the perceived "evil" present in the threat from Soleimani. And it harkens back to an earlier example of a parent protecting their child from the bogeyman beneath the bed. The child would not need protection if it were not for the presence of the bogeyman. Mandarani and Fakhruddin (2020) conclude their analysis with another discussion of justification, by reasoning that Trump at least found his actions to be justifiable and admirable — even though he presented very little information that would allow Americans to make that decision themselves. 
In her analysis of Trump's speech announcing Soleimani's assassination, Eiholm Kjær (2020) evaluates Trump's legitimatization of his actions against Soleimani. Eiholm Kjær relies on a definition of legitimatization from Reyes (2011), who views legitimatization as the specific process of justifying social actions in which the speaker must argue in favor of their actions through speech. A politician's main goal throughout the legitimatization process is to gain or maintain public approval or power (Eiholm Kjær, 2020). The latter is of particular interest to this thesis because of the speech's proximity to an upcoming presidential election in which Trump's name is on the ballot for re-election. Eiholm Kjær identifies a similar paternalist trend as Mandarani and Fakhrudding, in which Trump justifies his actions against Soleimani by claiming to have committed those actions to protect Americans from future terrorist acts. However, Eiholm Kjær specifies the referent of that protection as not just Americans, but specifically Americans abroad. By specifying the protectee in this paternalistic scenario, Eiholm Kjær argues that audience members can adopt a more humane view of both the protected and those who threatened the protected.

Humanizing both actors allows for a deeper moral connection to "us" and "them" identities: "these two categories broadly embrace the moral distinction between 'good' and 'evil,' where the referent object reflects the good while the threat represents the 'evil'" (Eiholm Kjær, 2020, p. 23; see also Harle, 2000). Accordingly, Eiholm Kjær notes a trend in Trump's diction that was used to reinforce this moral divide. For example, Trump used words like "murder" to describe Soleimani's actions, but the same actions (the act of ending another human's life, regardless of who the human was or how justifiable the action) were presented in less harsh language when they were committed by Americans. Words such as "stopped" do not hold the same weight as "murdered" (Eiholm Kjær, 2020, p. 24). Finally, Eiholm Kjær 
highlighted an unsurprising connection between Trump's divisive rhetoric and the positioning of himself as a hero in his heroic act to protect Americans from potential terrorists. He is not just the paternal protector of the nation, he is a victor in the ongoing fight against terrorism.

\section{Conclusion}

Since September 11, 2001, the United States has seen many tumultous changes. We have endured wars and vicious campaign cycles, each tinged with the rancid memory of the horrendous terrorist attacks from nearly two decades ago. Yet not much has actually changed in the way we talk about terrorism. Over the course of three presidential administrations following the attacks of $9 / 11$, we still see the same themes and rhetorical strategies emerge from the White House over and over again. Moreover, not much has changed in the way presidents discuss or rhetorically frame terrorists and terrorist threats (Rubin, 2020). From the public addresses they make regarding terrorism to the types of missions employed against terrorists in assassination efforts, a review of published literature reveals that all three of the presidents in office following the attacks of September 11, 2001 have behaved and communicated similarly—one after another, after another.

With that cyclical pattern in mind, Rubin (2020) warns Americans to recognize this pattern and prepare for its use in the future. On the matter, he posits, "the public needs to be on guard for the terror threat being manipulated so as to grab power for the Executive Branch... Leaders [often] seek to expand their power and urgent threats can be employed toward this goal" (Rubin, 2020, p. 167). Each operation has granted Americans the gift of yet another (eerily familiar) speech announcing the capture or assassination of that terrorist— just one year before a re-election campaign. This begs the question: why aren't we paying more attention? 
In this chapter, I reviewed many of the strategies employed in presidential rhetoric, as they pertain to terrorism. Such rhetorical strategies included presidents' definition (and redefinition) of American reality; a reliance of the old standards of American-isms like exceptionalism, exemplarism, interventionism, as well as a tendency to fall back on presidential paternalism; and the black and white "us" versus "them" dichotomy that paints a world in which unconscionable evil exists opposite innocent victims. Since September 11, 2001, plenty of scholarship has been published about these rhetorical strategies. However, little scholarship has been dedicated to the speeches I plan to analyze forthwith. The few articles dedicated to this subject were reviewed. But as a field, we must dedicate more time and energy to these speeches, as these three speeches have lasting implications for foreign policy, future presidential behavior and rhetoric, and for the American people. Moreover, it is not impossible that these speeches weilded great persuasive power over voters as they cast their ballots approximately one year after each of these speeches were delivered. With that in mind, we are ready to move forward to the next chapter, which will introduce the methods I intend to apply in my analysis of the three speeches delivered following the assassinations of three noteworthy terrorists. 


\section{CHAPTER III: METHODS}

As we explored in the last chapter, Americans have constructed our identity in a few ways throughout history. This is particularly true when we discuss matters of national security, and especially terrorism. In relation to the speeches delivered by Presidents Bush, Obama, and Trump following the assassinations of (respectively) Saddam Hussein, Osama bin Laden, and Qasem Soleimani, Americans position themselves as heroes, exemplars, protectors, and saviors - justified by American exceptionalism, exemplarism, and interventionism. Our nation's leaders, namely our presidents, take this superior identity one step further with the concept of presidential paternalism. Paternalism grants presidents the power to define social reality for the American public, to contextualize events, and to justify actions with their unquestioned authority and imprimatur.

These -isms, as I referred to them in the last chapter, are extraordinarily important to the way Americans view themselves, and will prove useful in this essay as they are applied to an analysis of the aforementioned presidential speeches pertaining to terrorism. They help to create a narrative in which we are the virtuous "us," poised against an evil "them." In a story, we might refer to these polarized characters as protagonists and antagonists. And if we are to look at the American response to terrorism in terms of a story, we must turn to the idea of narrative criticism and Fisher's narrative paradigm.

\section{Narrative Paradigm: Stories We Tell Ourselves}

Simply put, a narrative is a story. And in the groundbreaking essay in which Fisher (1984) introduces his narrative paradigm, he makes the argument that "humans are essentially storytellers" (p. 7). If storytelling forms the foundation of who we are as human beings, Fisher contends that storytelling must then also be the way we make sense of and interact with the 
world around us. He argues that we use the stories we are told and the stories we tell one another - whether nonfictional or entirely concocted — as lenses through which to view the world. We filter our own experiences through narratives, seeking narrative fidelity. Fisher (1984) explains that the process of testing narrative fidelity involves determining "whether the stories [we] experience ring true with the stories [we] know to be true in [our] lives" (p. 8).

As it pertains to the story of Americans' experience with terrorism, we all lived through (or at least learned about) the events of September 11. Whether we watched the towers of the World Trade Center fall on live television or read about them in elementary school history books years later, 9/11 was — and still is - a transformative experience for most Americans. We remember $9 / 11$ with heavy hearts and painful memories. It is an easily accessible memory, and therefore a readily available filter for stories anytime the word "terror" is mentioned. When news breaks about roadside bombings in the Middle East, it is almost second nature to situate the small-scale terrorist attack alongside the mass-casualty event that was 9/11 (Gul, 2020).

As humans, we compare tragedies. In much the same way that we use the death count in WWII concentration camps like Auschwitz as a metric for human loss (Owen, 2008), we compare the death toll of events and natural disasters to $9 / 11$. As I write this essay during a global pandemic hitting the United States particularly hard, Americans are currently inundated with news stories comparing the death toll of COVID-19 to the death toll of September 11, 2001. For example, Ward (2020) reports that "the coronavirus has now killed more people in the U.S. than the 9/11 terror attacks" (para. 1). Villeneuve and Hinnant (2020) compare the New York lives lost in 9/11 to the lives lost to coronavirus. Even more specifically, Ingraham (2020) compare the number of police officers lost to terrorist attacks to the number of police officers 
lost to coronavirus. Each of these examples demonstrate instances of using a narrative-in this case, the story of terrorism in $9 / 11$ - as a filter for experiences.

In addition to narrative fidelity, Fisher (1984) floats the idea of narrative "probability" or coherence throughout his essay. According to Fisher, probability refers to the degree of coherence within the story. In other words, narrative probability measures how much (or whether) the story presented makes sense and is consistent. This tenet of Fisher's narrative paradigm could prove useful in a rhetorical analysis - particularly when applied to Trump's speech following the assassination of Soleimani. As scholars such as Talmon and Heipertz (2020) already suggest, there is the potential for falsification in Trump's speech because of the lack of external evidence regarding Soleimani's terrorist actions. In other words, the tale Trump told in his speech may be rooted more in fiction than in fact.

Beyond narrative fidelity and coherence, a narrative criticism allows for the discussion of a story's composite parts. Although narratives presumably span nearly every human experience, each story shares a few common characteristics. Narratives come replete with characters (antagonists and protagonists), settings, plots, conflicts, and overarching themes across sequential events (Rowland, 2009). To complicate the presence of characters in a story, a compelling and credible narrative must have antagonists and protagonists of approximately equal power levels (Rowland, 2009). As discussed in chapter two, many Americans equate acts of terrorism and terrorist actors with evil incarnate. But the presumptive sheer evil was believed to be countered by the president's power. They felt protected by the Executive Branch of the U.S. government, as supported by the idea of presidential paternalism. 


\section{Close Textual Analysis: Words and Strategies to Tell Our Stories}

Serving as an umbrella over narrative criticisms resides the practice of close textual analysis (CTA). According to Browne (2009), "practitioners of CTA generally view their art less as a method per se than as a disciplined search for the linguistic particulars that eventually comprise the whole of a given rhetorical performance" (p. 63). They examine the minute details of a text to determine what work a text is doing in the world, and how the text is doing that work. They believe that form and content are intrinsically connected, in so far as the rhetorical style of the text is just as important as the overall message.

In $55 \mathrm{BCE}$, Cicero wrote De Oratore, in which he identified the five canons of rhetoric as invenio (invention), dispositio (arrangement), elocutio (style), memoria (memory), and pronuntiatio (delivery) (Fan). While memoria does not directly pertain to this essay's analysis because each of the presidents read directly from speeches prepared by members of their communication staffs and national security teams and therefore did not have to memorize their speeches, Cicero's remaining four canons will prove extremely relevant to the analysis to follow. With that in mind, I offer a quick review of those canons.

First, invenio or invention is the creation of a persuasive message within a communication and includes Aristotle's three proofs. In his treatise, Rhetoric, Aristotle (1926) identified three proofs of persuasion as ethos, pathos, and logos. A speaker's ethos can be interpreted and evaluated by a rhetorician in three ways: "good sense, good character, and good will" (Hill, 2009, p. 44). When a rhetorician evaluates a speaker's logos, they evaluate appeals to logic and reasoning. Aristotle's third proof, pathos, refers to "the emotional state of the audience, as produced by the speaker or speech" (Keith \& Lundberg, 2008, p. 39). Of course, in a speech delivered without an audience - as each of the three speeches analyzed in this essay were 
delivered - rhetoricians evaluate the emotional appeals in the speech and must make predictions about how the audience was intended to react emotionally.

Second, dispositio or arrangement refers to the structure or organization of a text and transitions smoothly into style. Third, elocutio or style allows the most flexibility in rhetorical analysis. It is through this canon that rhetoricians can analyze the techniques writers use to provide readers with clarity and emphasis. By analyzing a speaker's style, rhetoricians can pinpoint words, phrases, or themes to glean a deeper understanding of the text and its varied implications. As such, it is this third canon that will guide most of my analysis. Finally,

pronuntiatio or delivery allows rhetoricians to expand their purview from words on a page to the verbal and nonverbal delivery of the speaker.

\section{Three Texts: The Objects of Analysis}

As I considered my graduate thesis, I always intended to conduct a rhetorical analysis of presidential rhetoric. More specifically, I desired to focus my research on presidential rhetoric pertaining to terrorism response, as it forms such a foundational basis of my understanding of presidential rhetoric. After all, some of my earliest memories stem from the attacks of September 11, 2001. While I was alive for the tail-end of the Clinton administration, I was too young to retain any memory of his presidency. Instead, my memory to date only spans the Bush, Obama, and Trump administrations. Each presidential administration has operated under the lingering reminder of terrorist threats since that fateful day, and I hoped to look for a common thread that united each of the three administrations. That thread revealed itself on January 3, 2020, when the news broke of Qasem Soleimani's assassination. The news felt eerily familiar, as if I had experienced a similar breaking news moment following the assassination of Osama bin Laden 
eight years ago on May 2, 2011, and a similar moment following the capture of Saddam Hussein approximately eight years before that on December 13, 2003.

The circumstances felt familiar, as the nation and world watched surprised, and the American president delivered news of the termination of a terrorist's efforts (whether by capture or by assassination) against the United States. Moreover, each speech was delivered in the year before that president was up for re-election, and with each passing (eerily similar) situation, the circumstances felt conspiratorially coincidental. The content and delivery of the three speeches sounded familiar. Even the feelings welling up in my abdomen as I watched the speeches were familiar, as the well-rehearsed and strategically planned pathos appeals did their work in speech after speech after speech. My acknowledgement of this pattern prompted my selection of three texts. I chose to analyze the speeches delivered by Presidents Bush, Obama, and Trump announcing the news of their administration's assassinations or captures of the notable terrorists.

\section{Methodology for Analysis}

To conclude this brief review of two different methods of conducting rhetorical criticisms, it is time to introduce the methodology that will be applied throughout the present analysis. To be frank, there is not one single methodology that can adequately explain the communication phenomena explored throughout this essay. Rhetorical theory has not yet had to grapple with communication issues quite as episodic as the nearly eight-year cycle that results in speeches such as the ones delivered sequentially by Presidents Bush in 2003, Obama in 2011, and Trump in 2020. As such, current rhetorical theory is insufficient to grapple with these texts.

Therefore, I will rely on a combination of CTA and narrative criticism to guide my

analysis, although the themes and meanings that emerge from the three speeches will serve as the ultimate guide for my interpretation. Through close analysis, the direction of this essay will be 
revealed as similar themes and strategies emerge between the three presidential addresses. CTA, the framework of narrative criticism, and to a lesser extent Fisher's narrative paradigm will provide guidance and the flexibility to allow the speeches to speak for themselves, as it were. The latter, Fisher's narrative paradigm, will be explored primarily in the seventh chapter, when I synthesize all three speeches and identify which speeches had the highest and lowest degrees of narrative fidelity and probability (or coherence).

With that in mind, I expect to analyze these three speeches as sorts of remakes or sequels. Although they are delivered in intervals spanning entire presidential terms, they occur in surprisingly similar contexts. Delivered in close proximity to re-election campaigns and written about terrorism enacted against the United States by malicious Middle Eastern (and more specifically, Islamic extremist) terrorists/terrorist organizations, the only notable differences are the characters in the story. Each speech sports a different cast of antagonists and protagonists. And with each passing rendition, the president speaking contributes to a larger American narrative - in much the same way that a sequel contributes to the overall story of a book, television, or cinema series. With that in mind, the first component of my analysis will seek to answer the following questions: what does the speech do to move the narrative along? How does the speech complicate or clarify the narrative? In this way, I open by noting the existence of an overarching narrative emanating from the Commanders-in-Chief, and then interpret and critique specific terrorism-related speeches from Presidents Bush, Obama, and Trump to determine how they function within the larger narrative.

These speeches are also unique when compared to other genres of presidential speech, because prior to the moment at which a speech is delivered, the president cannot reveal any information about the speech's content. Human lives and matters of national security are on the 
line, and these speeches are the public's first glance into a secret operation against a foreign actor. Once the speech is delivered, it must stand alone as the only window into the president's perspective on the assassination or capture of the terrorist, as it is the only time the president can communicate about the action prior to its corruption and manipulation by outside actors after the news breaks. With that in mind, these speeches serve as the only time that presidents have the opportunity to justify their actions uninterrupted by pundits' or analysts' interjections. Therefore, I plan to interpret these speeches in such a manner that I can reveal the presidents' respective justifications for assassinating or capturing a terrorist, guided by the following questions: How does the president justify his actions against the terrorist? What implications does the president's justification have for American identity, reputation, or image?

In the phrasing of these questions, I intentionally refer to just one speech because I plan to analyze each president's speech separately. Therefore, each speech will receive its own separate analysis chapter. I will conclude the essay with a chapter dedicated to synthesizing the three speeches and exploring ways that the three speeches fit into a larger political campaign context and narrative infrastructure. As a result, the first speech up in the docket for analysis is President Bush's 2003 address announcing the capture of Saddam Hussein. 


\section{CHAPTER IV: GEORGE W. BUSH AND THE}

\section{CAPTURE OF SADDAM HUSSEIN}

A mere seven steps - that is all it took to cross from the entrance to the Cabinet Room to the podium bedecked with the Presidential Seal.

But those seven steps made history.

Rather, they delivered President George W. Bush to the microphone from behind which his words made history. Those footsteps would ring out with eerie familiarity across the next two presidential administrations as Presidents Obama and Trump would later make their ways to their own podiums, to deliver their own proclamations, to announce that another terrorist threat had been vanquished.

"Good afternoon,” Bush (2003) began. "Yesterday, December the thirteenth, at around 8:30 PM Baghdad time, United States military forces captured Saddam Hussein alive” (para. 1). From the nearly twenty-four hours the Bush administration allowed to lapse between Hussein's arrest and Bush's Sunday afternoon address, to the attribution of credit to unspecified "United States military forces," there is much to unpack even in this brief introduction. Perhaps the most meaningful nugget of this introduction, though, is the resonant last word: "alive."

In the president's signature sluggish Texan twang, Bush took his time breaking the news. A pregnant pause will live on in infamy in the space between "Hussein" and "alive," where the latter elevates the statement from a high-stakes obituary to an account of American victory. The unnamed forces responsible for Hussein's capture conducted a swift and remarkably clean mission without a single casualty — even their intended target was brought in alive. Even though Hussein's life and career as the president (read, “dictator") of Iraq was rife with deaths and terror, Americans granted him a trial. More importantly, Americans offered justice to the Iraqi 
victims of Hussein's reign of terror by taking precautions not to assassinate him during their mission. When read in this light, it is challenging not to view Hussein's American captors as anything less than heroic.

Beyond celebrating the unnamed forces' acts of heroism and bravery, Americans also won an opportunity to revel in celebration: we caught the bad guy. Two years after the brutal attacks of September 11, 2001, the nation was hungry for a win in the War on Terror.

Admittedly, Hussein played no role on 9/11. But to grieving Americans, a terrorist is a terrorist, right? And, of course, further validation of his terrorist-status was heightened since he hailed from the Middle East.

In his speech, Bush (2003) championed himself (and his administration) as the harbinger of justice to a justice-starved Iraqi people: "the former dictator of Iraq will face the justice he denied to millions" (para. 1). A few moments later, Bush addressed these Iraqis directly. $\mathrm{He}$ declared, "For the vast majority of Iraqi citizens who wish to live as free men and women, this event brings further assurance that the torture chambers and the secret police are gone forever... I have a message for the Iraqi people: You will not have to fear the rule of Saddam Hussein ever again" (Bush, 2003, para. 3). In a deeply paternal move, Bush believed he knew what was best for the people, both from his nation and from a Middle Eastern nation over six thousand miles away. Because the American electorate largely did not have access to the same sources of information as the president, they could not be considered capable of making such important decisions about their safety and wellbeing —at least not as capable as the president. Just as a child needs the protection of his or her parents, President Bush declared his constituents in dire need of his presidential protection. As any good father might, he vanquished the fears he knew they held. Everyone could rest easily that night, for Bush and the Americans arrested the monster 
that went bump in the night. We delivered justice swiftly. And we managed to bring the bad guy in for questioning alive.

Therefore, this paternalistic mission began with an initial focus on ensuring that Americans felt safe (or at least safe enough). President Bush made sure to present himself as a credible leader who was taking this threat seriously, and worked hard to reassure the nation that their safety was in good hands (Maggio, 2007). Although the job of contextualizing crises (such as devastating terrorist attacks) almost always falls to a nation's leaders, this was more true than ever before for President Bush in the wake of 9/11. At least early in the crisis, Bush was called upon to explain how and why this tragedy befell Americans - the once exceptional and untouchable "chosen" nation (Childers, 2007).

And for the most part, his explanations had to be enough for the American people, as we had few avenues to which we could turn for more information. After all, it stands to reason that our nation's leaders know more than average Americans when it comes to matters of national security and terrorism (Rubin, 2020). Farrell and Young (2003) questioned why more Americans did not question policies as they were revealed after 9/11, regarding terrorism and the eventual war in Iraq. The answer, now a wholly disatisfactory one, comes down to the fact that Bush's paternal rhetoric shut down debate and questioning by communicating in a once-reassuring way, trust me... I know what's best for you right now. In that moment, not only did the president and his advisors claim to know what was best for American citizens, they also claimed to know what was best for the world's citizens too as they began to contemplate a War on Terror and retaliation missions against those responsible for the attacks of September 11. Once again, we are left to consider that American exceptionalism, exemplarism, and interventionism play a role in many of our foreign and domestic policymaking decisions. 
Before we can discuss the implications of the aforementioned American-isms on this speech and subsequently on American identity as laid forth by President Bush, we must first explore the elements of narrative at play in President Bush's speech. Our story begins with a recount of the scene. The setting of Bush's speech commemorating the capture of Hussein was the Cabinet Room of the White House just after noon on Sunday, December 14, 2003. Named for the group it most often serves - secretaries of the presidential cabinet - the space was a late addition to the West Wing in 1902 (The White House Archives: President George W. Bush, n.d.). The dominant feature of the space is, of course, the large, oval, mahogany table surrounded by leather-backed chairs reserved for the president, vice president, and each member of the cabinet. The room looks out through several tall paned windows onto the Rose Garden (The White House Archives: President George W. Bush, n.d.).

At one end of the room sits a white fireplace. It was against that backdrop, flanked on either side by the American flag and the navy-blue flag of the American president, that Bush delivered his speech. Although the eagle at the center of the flag's presidential seal faces the olive branch in its dexter talon (as a symbol of the nation's ongoing pursuit of peace), the flag behind Bush is draped such that the eagle's sinister talon is highlighted on display. The latter talon clutches thirteen arrows, and has historically been celebrated for its memorialization of the nation's strength throughout past flirtations with war (Costello, 2018). This was probably a coincidence, but the war-symbolizing arrows operated as an omen of sorts. They loomed ominously over the scene, as Bush opened his mouth and began to speak.

The next component of narrative which demands our attention is the matter of actors. As a spectator of the speech all these years later, it is challenging to determine who-if anyone - sat in the audience before Bush. Regardless, the footage reveals a single man onscreen, apart from 
the suit-clad hand that opens the door to the Cabinet Room. Bush is the sole actor for the better part of four minutes. As such, he served as the sole narrator, relaying information to his audience about the successful capture of Saddam Hussein. He injected himself, his government, and his presidency into the story when he inserted first-person pronouns such as "I," "we," and "us" into his speech. Therefore, Bush existed in this scene as a first-person narrator. Listeners and viewers had to trust Bush's version of the story, because at the time of the address, his words were the only version of the story to which the American people had access. Audience members could presumably trust Bush's speech, because he was the president at the time of its delivery. As president and as Commander-in-Chief of the United States military, one could reasonably expect Bush had access to top-notch information regarding matters of national security. Specifically, in matters that involved Saddam Hussein, the American people had to assume that Bush was quite familiar about the subject matter of the speech. In other words, the factual content of the speech was presumably all accurate, factual information, thereby fitting Bush into the role of a reliable first-person narrator.

Bush is also the primary protagonist in the retelling of the story of Hussein's capture. He did not need to reiterate or re-emphasize his role as Commander-in-Chief, because he spoke from behind the seal of the president and directly in front of a flag bearing the same insignia. Choosing to deliver the news of Hussein's capture in the room most often occupied by the heads of the Executive branch of the American government further reminded audience members that Bush was in command. Bush's boots were not dirtied by the mud in Baghdad that day, but there was no mistaking that Bush was in charge. At the end of the day, it was Bush that ultimately made the final call to capture Hussein. As such, from thousands of miles away, Bush figuratively led the heroes of the hour-those unnamed "military forces" - into a battle for Hussein. Hussein 
lost the fight, and Bush reigned victorious. The president spared Hussein's life, and Bush emerged magnanimous. He did not stoop to Hussein's level of murdering for the sake of murdering. Therefore in this instance, Bush represents the ideal of justice - rather than vengeance — since he and his administration sought only to capture Hussein. Bush's victory and chivalry secured his status as the protagonist of the story. In the tale Bush told about capturing Hussein alive, there was no mistaking that Bush was a hero. Like bounty hunters of the Wild West, Bush was the good guy, the man responsible for catching a wanted terrorist in the ongoing War on Terror.

This is not the sole narrative. In fact, many others exist surrounding the invasion of Iraq and the eventual capture of Saddam Hussein. Each version of the narrative casts the characters (or actors) in a different light. Sometimes the villains and heroes are presented exactly opposite how Bush presents them in his speech following Hussein's capture. For example, in his chapter introducing the narrative perspective, Rowland (2009) presents a compelling perspective from which to view the story of Hussein's ultimate abduction by American "military forces":

Saddam Hussein was a brutal dictator, a modern day Hitler, who viciously oppressed his own people and was seeking weapons of mass destruction in order to threaten the world. In this narrative, President Bush and others who supported military action against Iraq, are treated as heroes who are willing to fight in order to rid the world of this terrible dictator. Others see the situation through a very different narrative lens. They agree that Hussein was a bad leader, but put much of the blame for the present situation on failed U.S. policy in the past. In this view, U.S. support during the Iran-Iraq war (1980-1988) propped up Hussein and we are now reaping the terrible harvest of that decision. In this narrative, the United States is not heroic, but an arrogant and selfish bully that is trying to 
control the world. The invasion of Iraq was not an act of heroism, but a foolish attempt to enforce American domination over another nation. (p. 121)

From Rowland's viewpoint, the role of instigator and antagonist falls neatly into the lap of the American government. While George W. Bush was not president during the Iran-Iraq War (and his father was not elected until 1989), he still shoulders some of the burden of his predecessors simply because he was elected president. Moreover, as the one responsible for ordering Hussein's capture in 2003, Bush was the face of the act Rowland criticized. Rowland's critique labels the American government a bully for their emphatic reliance on interventionism. This is fascinating, because as we will later discover, Bush calls the villain in his story-Hussein — the "bully."

Another, equally compelling interpretation of the story exists and should be explored. In this contradictory version of the narrative surrounding Hussein's abduction, no weapons of mass destruction were found in Iraq (CIA, 2007). Despite the Bush administration's best efforts to convince the public otherwise, Saddam Hussein played no role in the attacks of September 11, 2001 (Althaus \& Largio, 2004). That said, Hussein was far from a pure and innocent victim of kidnap. His record of crimes against humanity was a long and bloody one. But since no such weapons of mass destruction existed in his nation and Hussein was not guilty of American deaths on 9/11, the reliability of Bush's narration must necessarily be scrutinized if we are to provide a fair narrative criticism of his speech.

The eight-year occupation of Iraq by American military forces was expensive on many fronts - demonstrated by the extensive loss of life from both sides and by the trillions of dollars spent on the Iraq War (Congressional Budget Office, 2008). My point here is not to belittle the war effort or in any way to diminish the financial and humane cost of the American invasion of 
Iraq. Rather, I include this truncated summary as a means to describe how Bush's reframing of these events and the eventual capture of Hussein could be interpreted vastly differently than he and his speechwriting staff presumably intended. This interpretation paves the way for a reading of this speech in which Bush is unequivocally an unreliable narrator.

As an unreliable narrator, Bush did not need to specify the instance of terrorism when discussing Hussein's action. Any mention of terrorism so soon after the horrors of September 11 would inevitably force Americans to recall images of death and destruction at the World Trade Center and the Pentagon and the field in Pennsylvania. Still reeling from the tragedy and still traumatized by the attack on our otherwise seemingly impenetrable and impervious nation, Americans could be trusted to fill in the gaps themselves. The Bush administration was surely relying upon a fallacious syllogism — the enthymeme (Aristotle, 1926) — wherein in order to foster support for the invasion of Iraq, Americans would connect the dots between vague terrorism, 9/11, and Saddam Hussein.

Much to my own chagrin (and to the gut-wrenching dismay of countless families who watched their loved ones enlist—some never to return home again), it worked (Gershkoff \& Kushner, 2005). Support for the Iraq War was uncharacteristically high among Americans (Rosentiel, 2008). While retrospect offers unquestionably greater clarity surrounding the events of the American invasion of Iraq, as well as surrounding the capture of a still-alive Saddam Hussein, it is challenging not to see a "rally 'round the flag" effect operating in full swing at this particular moment in American history.

Many scholars agree that "an emerging military crisis—especially if it is sudden, dramatic, and international in scope - is one of the few factors sufficient, in and of itself, to trigger sustained increases in support for the president" (Lambert et al., 2011, p. 343; see also 
Baker \& O'Neal, 2001). The operative word in this understanding of the "rally 'round the flag" effect is "sustained." Bush benefitted in monumental ways from the attacks of September 11. His favorability rating spiked to a staggering $90 \%$ in the immediate aftermath of that fateful dayhigher than any president's recorded favorability rating before him (Lambert et al., 2011). In addition to the "rally 'round the flag" effect, this seemingly inexplicable phenomenon can also be understood through social identity theory, "which generally assumes that people are motivated to maintain a positive view of the groups to which they belong, especially during intergroup conflict. [Social identity theory] suggests that an attack against the United States should bolster support for the president, as well as for symbolic representations of the ingroup (e.g., the flag)" (Lambert et al., 2011, p. 344). As Americans reeled from loss and fear, Bush-as a primary symbol of the nation — enjoyed unprecedented levels of support.

Americans craved actions taken against the person or persons responsible for their pain. They hungered for retribution in some form or another. And in turn, they largely supported military action against anyone associated with terrorism on a sustained basis. Two years after the attacks of 9/11, they were so ravenous for vengeance and justice that they supported the Iraq War en masse. All Americans required from Bush in his public addresses was an opportunity to connect the dots between terrorism and Hussein.

Bush granted their wish with such statements as "we still face terrorists who would rather go on killing the innocent than accept the rise of liberty in the heart of the Middle East. Such men are a direct threat to the American people, and they will be defeated" (Bush, 2003, para. 6). I will continue to explore these lines in greater detail later in this chapter. But for our purposes now, this vague connection exemplifies Bush's implied linkage between terrorism writ large and Hussein specifically (in this excerpt, referred to as "such men"). The proximity of the two ideas 
further concretized Americans' association of Hussein with the terrible terrorist activity of September 11, 2001-although I cannot stress this enough: the two were not related in any way, shape, or form. Additionally, by drawing audience members' attention to the specification that Hussein (and "such men" like Hussein) prefer to "[kill] the innocent" over killing any other entity planted the notion in this speech that Hussein is evil to a particularly repulsive degree. He and his "men" did not just kill opposing military, militia, or guerilla forces in Iraq—-they killed innocents. At Hussein's behest, Iraqi terrorists killed civilians - women and children and unaffiliated men—by the hundreds of thousands, as a war crimes tribunal would ultimately conclude in 2006 (Bassiouni \& Wahid Hanna, 2007).

Identifying any person or group as "evil" (as Bush did suggested in this speech) enables audiences to tap into their own past—-filtering through personal experiences and media exposures - to find villains whom they can liken to the "evil" Other (Hariman, 2003). In a matter of moments, these bad guys earned a permanent spot on a list of all other bad guys encountered by audiences. And in that quick association, it is hard to prevent other associations from forming. For example, by extension, all other people from the terrorists' places of origin might quickly be lumped into the category of "evil." The same can be said for the overarching religion associated with the act of terrorism. Though it was by no means justified, this association blame-game led to an unsurprising and dramatic uptick in the number of hate crimes in the United States committed against people of Middle-Eastern origin and who practiced Islam (Disha et al., 2011).

In response to both the initial terrorist attacks of September 11, 2001 and to the hate crimes after the fact, President Bush attempted to recreate Americans' social reality by associating the Taliban with its corresponding terrorists—while disassociating Middle-Easterners and Muslims from terrorists overall. In walking this tightrope between association and 
disassociation, Bush made the argument that although evil exists, Americans must leave the innocent alone (Maggio, 2007), thus redefining not only who constituted a "terrorist" but also what constituted "evil." This work continued well into subsequent presidential administrations, although the emphasis eventually turned from what constituted "evil" in the past, to the prevention of future constitutions of evil, as we will see with Trump's ultimate assassination of a terrorist to prevent terrorist attacks against the United States.

That said, we must not forget that Bush was quick to call the terrorists responsible for 9/11 "evil" in the first place, thereby irrevocably casting them in an immoral light from the very beginning (Brydon, 2004). Along with the discussion of morality, Bush seamlessly incorporated a discussion of religious morality. As Brydon (2004) discovered in his review of speeches made by President Bush in the immediate wake of September 11, Bush's reliance on God-based language was prevalent (though not as prevalent as some other presidents). To some degree, in the window of immeasurable grief and shock and horror, this reliance on a higher power made sense. Americans, I believe, almost needed a reminder that some higher power was in charge. And it made sense that the man in charge of the hour, the President of the United States and leader of the free world, would be the one to deliver that reminder. That said, although religious language seemingly worked in the immediate days and weeks following $9 / 11$, the rhetoric lost its resonant effectiveness as time dragged into subsequent administrations as Americans distanced themselves from the presidency due to the lapse in time since September 11, 2001.

Moreover, I reason that this "rally 'round the flag" effect and the implication of social identity theory in the explanation of Americans' support for Bush's decision to pursue Hussein and invade Iraq can be better understood within the context of what I call the American-isms. As 
I explained in chapter two, these -isms form the foundation of much of Americans' national identity. Here, I refer namely to American exceptionalism, exemplarism, and interventionism.

To review, exceptionalism alludes to the notion that America (and through the transitive property, Americans) was a nation chosen by God. It is a vain understanding of our nation and our governance as superior and exceptional. Exemplarism takes exceptionalism one step further and promotes the United States as a role model of political possibility. Exemplarism therefore allowed Bush to place upon a pedestal (for all the nations of the world to see) the United States as an example of how democracy can and should work. Lastly, interventionism satisfies the expectations of exceptionalism and exemplarism by granting Americans permission to intervene in the affairs of other nations to show them how it's done. After all, Americans are exceptional and should shine as examples across the international amphitheater. Should we not then also intervene graciously on behalf of all the other nations to bless them with even a sliver of our greatness?

These American-isms, I argue, are the most prominent features of our national identity when we feel threatened. September 11, 2001 marked the first time in a very long time (in our nation's comparatively very brief history) that America was threatened and American lives were lost on our own soil. Hence, we clung even more forcefully (some might say "patriotically") to the truths we held most self-evident, and we rallied behind our Commander-in-Chief, behind the federal government, and behind our men and women in uniform. Surely they would remind us and the rest of the world of our greatness.

In those moments of uncertainty, it did not immediately matter that our president might not be the most reliable of narrators. Because as we desperately clutched onto the weakening mantra that we (and our president) were the heroes of our story, we knew one thing to be true. 
Our capital-T "Truth" in 2003 was that Saddam Hussein was the villain. In this narrative there was no question that Hussein was the antagonist.

In announcing Hussein's downfall at the hands of the mighty "military forces," Bush made abundantly clear his own distaste for Hussein as evil. In one example, Bush (2003) labelled Hussein a "bully," akin to the leader of a high-stakes ring of schoolyard meanies, when he referred to Hussein's capture as "the end of the road for him, and for all who bullied and killed in his name" (para. 2). In an interesting way, the selection of "bully" as the descriptor for Hussein's reign of terror secures Bush as a paternal actor.

As a patriarch, Bush and his "military forces" intervened not only to prevent terrorist acts and preclude the manufacture or administration of weapons of mass destruction, but also to reiterate his role as a father figure of sorts. His intervention demonstrated once again that he acted benevolently because he knew what was best for the people of his nation and for the people of Iraq-like a father talking to a school administration about a bully responsible for taking lunch money from his son or daughter. The notable difference between the two scenarios is that while the child can now enjoy a more peaceful lunch of square "pizza" (though the smothering of tomato-sauce between cheese and crust present in most school cafeterias around the country, in an ill-fated attempt to disguise cardboard, can scarcely be called "pizza") every afternoon, Iraqis could now theoretically enjoy access to the democratic freedom America exemplifies-thanks to the intervention of American "military forces" and to President Bush.

This notion reiterates the idea that Bush's actions were fueled by the American-isms for he just knew, without a shadow of doubt, that what the Iraqi people really yearned for was the kind of freedom enjoyed and exemplified by Americans. In fact, similar sentiments were reflected by other members of Bush's administration, in which Vice President Cheney and 
Secretary of State Rice argued that Iraqis craved freedom akin to the freedoms granted by the American government (Alessandri et al., 2015; Cheney, 2002; Rice, 2005). In addition to freedom and democracy in Iraq, Bush also planted the seed of the American Dream into one portion of his speech in which he directly addressed Iraqi listeners: "The goals of our coalition are the same as your goals," Bush (2003) declared, "sovereignty for your country, dignity for your great culture, and for every Iraqi citizen, the opportunity for a better life" (para. 3). That suggestion of the American Dream through the phrasing of a "better life" suggests that Bush believes the lives Iraqis led prior to Hussein's capture were, at their core, deplorable. Under any government unlike America's, the lives of any nation's citizens must surely be lacking by comparison. In the absence of democracy and freedom, those suffering peoples must surely ache for something better. They must dream about a nation and a livelihood closer (if not identical) to those enjoyed by American citizens...

As someone who has never stepped foot on Iraqi soil or lived as an Iraqi or really even interacted deeply with an Iraqi immigrant to this country, I cannot say with any certainty that Iraqis did not want to experience that kind of freedom. Certainly, after years and years of enduring Hussein's brand of dictatorship, torture, and overall oppression, even the slightest modicum of freedom probably sounded about as refreshing as a cherry popsicle on the hottest day of the year. However, Bush's presumption that he knew best (for a people he did not know) reeked of the ethnocentrism and American-style colonialism (Cirincione, 2003) that rests as a foundation beneath each of the American-isms. At times, his American ethnocentrism also sought to emphasize what a great and important gift he and his nation bequeathed upon the people of Iraq. 
Some carefully employed instances of polysyndeton offer a mechanism by which to emphasize the expansiveness of his gift: "in the history of Iraq, a dark and painful era is over. A hopeful day has arrived. All Iraqis can now come together and reject violence and build a new Iraq" (Bush, 2003, para. 4). A noticeable pause rests between each passing "and" in the last sentence of that quotation. And in the moment between the introduction of each new piece of the significant gift Americans graciously presented to Iraqis, anticipation is built, as if to say “wait... there's more!" In these presentations of Hussein as the villain — through his vague connection to terrorism and through his clear oppression and torture of Iraqis throughout his tenure as the nation's dictator/president—and the Americans as the unequivocal and omnibenevolent heroes, Bush also works to deepen the chasm between "us" and "them."

As I pressed red pen to paper and began the grueling analysis of these three presidential speeches, I anticipated to find that the employment of the first-person pronoun, "us," was reserved exclusively to refer rather ironically to citizens of the U.S. Conversely, I expected that the impersonal, third-person "them" would be used in association with everyone not affiliated with the United States. Perhaps this expectation was born from my own biased (and-due to the influence of the American-isms—privileged) status as an American citizen. Perhaps this stemmed from the more pressing reality at the time, because I began the analysis portion of my thesis in the final days and weeks of the Trump administration.

For reference, my undergraduate equivalent of a master's thesis was a comparative rhetorical analysis of Franklin Delano Roosevelt's and Donald Trump's first inaugural addresses and how they communicated, challenged, or created fear(s) held by the American public they were recently elected to serve. I reference that essay here, several years later, because even then, it was evident that President Trump had an interesting way of employing pronouns in his speech. 
I will explore this trend (as it persisted throughout his entire stint in the White House) in much greater detail in chapter six, when I analyze Trump's speech announcing the assassination of General Qasem Soleimani. However, I include this interjection here because it colored the way I remembered and understood presidential pronoun usage. Caught in that Trumpian way of thinking, that analysis and the last four years under the Trump administration forced me expect first-person presidential pronouns to be either exclusive to a base of supporters or at the very least, to exclude anyone who is not American by birthright. It came as quite the shock to me, then, when I quickly realized this was not the case nearly two decades ago.

In fact, Bush's speech commemorating the capture of Saddam Hussein includes newly liberated Iraqis in his employment of the ever-familiar "us" versus "them" dichotomy in speeches surrounding terrorism or foreign affairs. As first discussed earlier in this chapter, Bush (2003) includes Iraqis as innocents when he employs the pronoun, "us," and says, "we still face terrorists who would rather go on killing the innocent than accept the rise of liberty in the heart of the Middle East. Such men are a direct threat to the American people, and they will be defeated" (para. 6). Despite this message's preface, in which Bush (2003) says, "I also have a message for all Americans" (para. 6), there is no mistaking that same message can be interpreted from the perspective of Iraqis and Americans alike. This dualist interpretation is aided by extensive passages before this point, in which Bush directly addresses Iraqi citizens and includes them in his justification for capturing Hussein. If the innocent people of Iraq were, in fact, a hefty part of the reason Bush ultimately chose to give the order to capture Hussein, it stands to reason that those individuals (still inhabiting a war-torn and relatively unstable Middle Eastern nation, now experiencing greater political upheaval in the absence of their former president) would also still face terrorists willing to set aside morality in favor of killing innocents to pursue 
their cause. If that is the case (and I argue it is), Bush's "we" in this section of the speech includes not only Americans, but necessarily also Iraqis.

In this same passage, there is a separate implied "us" which apparently does not include Iraqis. I am, of course, referring to the named "American people" which Bush claims are still under imminent threat from terrorists like Hussein. In the clause immediately following this exclusive and implied "us," Bush (2003) drops a threat of his own: "they will be defeated" (para. 6). In this clause, "they" refers to antagonistic terrorists like Hussein and his "men." It is important to note that in this specific passage, Bush does not attempt to hide his classification of "them" as evil and villainous, compared to the implicit and explicit usage of "us" as innocent in the speech.

Running parallel to Bush's threats are the amplifications of American greatness and heroism throughout the speech:

The success of yesterday's mission is a tribute to our men and women now serving in Iraq. The operation was based on the superb work of intelligence analysts who found the dictator's footprints in a vast country. The operation was carried out with skill and precision by a brave fighting force. Our servicemen and women and our coalition allies have faced many dangers in the hunt for members of the fallen regime, and in their effort to bring hope and freedom to the Iraqi people. Their work continues, and so do the risks. Today, on behalf of the nation, I thank the members of our Armed Forces and I congratulate them. (Bush, 2003, para. 5).

As is evidenced in the passage above, Bush does not attempt to take all the credit for Hussein's capture. Rather, he lathers complimentary terms across his description of Americans' work in the manhunt for Hussein. If not for the "superb" and "brave" and "skill[ed]" and "precis[e]" (Bush, 
2003, para. 5) analysts, soldiers, and advisors, the successful capture of Hussein alive-let alone Bush's present speech—would have been impossible.

Indirectly, he likens the hunt for Hussein to a search for a needle in a haystack, wherein intelligence analysts managed miraculously to locate the wanted villain in "a farmhouse outside the city of Tikrit" (Bush, 2003, para. 1). A man like Saddam Hussein could not hide from the greatness of the American government, from the omniscience of the American military, outside the reach of the American president's orders. As the heroes of this story, America and, by extension, Americans are too exceptional to be deterred by a farmhouse tucked at the center of a haystack called Iraq. The odds were slim, and the search was an uphill battle from the start, but American operatives were more than up for the task. They accomplished their mission "swift[ly]... [and] without casualties" (Bush, 2003, para. 1).

Without doubt, Bush presents the capture of Hussein —in his telling of the story—as a victory. But it is not the final victory, not by a long shot. Following the conclusion of Bush's speech, the War on Terror would be fought for many years to come. Therefore, in the concluding remarks of his speech, Bush emphasizes that although Hussein's capture is not the final climax of the story, it is certainly a high point:

The war on terror is a different kind of war, waged capture by capture, cell by cell, and victory by victory. Our security is assured by our perseverance and by our sure belief in the success of liberty. And the United States of America will not relent until this war is won. (Bush, 2003, para. 7)

In this passage, Bush reiterated that "our" American victory was assured because of our exceptionalism. "Our" American identity would protect us and fuel us through the low points between victories. 
Regardless of to whom or to which groups Bush refers with his careful pronoun usage, there is a great deal of pathos at play in these passages. No matter how we look at the situation, Bush is clearly capitalizing upon Americans' anguish after 9/11. Our collective fear and grief paved a path forward for Bush to further his foreign affairs agenda — which included the invasion of Iraq for alleged terrorism purposes and to capture Saddam Hussein. Our thirst for revenge allowed us to view Bush and his actions as heroic in a narrative colored through blood red-tinted glasses.

Heightened emotions surrounding Hussein and his capture offered the Bush administration a mechanism to garner support behind the decision to act. By extension, they also served to increase Americans' favorable view of the presidency overall in a remarkable application of the "rally 'round the flag" effect. Combined, our fear, grief, and bloodlust enabled us to unite (or rally) around our president (symbolic of our nation and our flag - signifiers supplied with meaning by the president) in a shared demonstration of patriotism. We were proud that our nation accomplished the eradication of a terrorist threat and Iraqi terrorizer. And we were comforted by the knowledge that our president heard our fears and acted upon them. We found relief in the confident paternalism of the presidency. A reminder that Bush acted in Americans' best interest was wound into every facet of his verbal and nonverbal delivery.

Bush's voice did not quaver in the delivery of this short speech. For audience members exclusively listening to the speech, this lack of trembling might have been reassuring. Bush sounded confident in his decision and unflappable in his delivery-his tone equal parts authoritative and solemn. For audience members tuning into the speech through their televisions or computers, Bush's delivery could be interpreted accordingly. 
Evident in the stoic stacking of his still shoulders, there was a sense of ease delivered through Bush's paternal delivery. As his eyes darted from one end of the teleprompter to the other, viewers were reminded of the fastidiousness of this speech. Americans understood the necessity for brevity, because they were still smarting from the sting of an attack on their own country. With those fresh memories in mind, viewers were reminded of how monumental a moment this was, because how Bush handled this address could have far-reaching consequences. The announcement of Hussein's capture, his removal from the international stage, required delicacy—at least by the president. As viewers and listeners alike tuned in to Bush's address, it was impossible to separate the man from the office. The speech did not need to be delivered in the Oval Office to remind folks that Bush was the Commander-in-Chief. The Cabinet Room sufficed. Frankly, the moment did not even necessitate the inclusion of the presidential seal before and behind him as he spoke, because Bush's delivery was reverent, reflective, assertive, and diplomatic. It was presidential through and through.

The same cannot be said for other announcements of Hussein's capture that were made that day, although an array of Americans' emotions rang loud and clear in the delivery and reception of each of those addresses as well. To demonstrate, the announcement of Hussein's arrest in Baghdad by the United States civil administrator in Iraq, Paul Bremer, was met with resounding applause, hoots, hollers, and whistles from a room full of journalists. Bremer walked up to his own podium and simply announced, "ladies and gentlemen, we got him" (The capture of Hussein, 2003). The cheers in that room echoed the sense of triumph many Americans felt with the proclamation of Hussein's abduction.

The content of Bush's speech was the most important part of that telecast, so it is not surprising that the camera did not pan around the Cabinet Room to reveal whether or not anyone 
else occupied the space as Bush delivered the news of Hussein's capture. After all, the focus was intended to fall directly onto President Bush throughout his important address. To pan around the room, or to show a shot of others in the room, would have distracted from the momentousness of the occasion. Moreover, to include other actors on the scene might have diluted Bush's role as the sole paternal hero, though countless others played critical roles in the successful capture.

Nevertheless, Bush probably delivered his speech before an audience of White House staffers, speech writers, military advisors, and a small film crew. Privy to at least some of this information before the start of his speech, these individuals knew what the address contained. They were prepared for the announcement. Otherwise, I imagine that the reaction to Bush's (2003) statement, "United states military forces captured Saddam Hussein alive” (para. 1) would have forced a pause for celebration. Spectators in the room would likely have loudly expressed their joy at the delivery of justice to Hussein. They would surely have delighted at the news that the "former dictator of Iraq will now face the justice he denied to millions" (Bush, 2003, para. 1).

Many years would pass before another president would make another announcement, but here too, the ideas of justice and unity would prevail once more. Additionally, familiar applications of the oft-discussed American-isms would sprinkle the pages of not only President Obama's address announcing the assassination of Osama bin Laden, but also President Trump's address following the killing of Qasem Soleimani. And in each subsequent episode of the recurring story, Exceptional Paternal American Heroes Triumph Over Big Bad Terrorists, other eerie similarities can be identified. Therefore, it is practically impossible to evaluate these three speeches in a vacuum, because they build upon one another. The way each episodic chapter of the overall narrative is crafted and delivered has monumental implications on the way Americans 
perceive our own identity. With that in mind, we shall transition now to an analysis of President Obama's (2011) address, as influenced by President Bush’s speech just eight years earlier. 


\section{CHAPTER V: BARACK OBAMA AND THE}

\section{ASSASSINATION OF OSAMA BIN LADEN}

Eight years after Bush stood behind a podium in the Cabinet Room and announced that Saddam Hussein was brought in alive, President Obama delivered his own address announcing the eradication of yet another Middle Eastern terrorist threat. This time around, the threat was vanquished with the unyielding repose of death. Justice was doled out to the terrorist mastermind behind 9/11 in a proportional response for the thousands of innocent lives that were vanquished on that terrible day (9/11 Memorial \& Museum, 2021).

However, before we delve into our exploration of the intricacies of Obama's speech and its implications on American identity, we must first set the scene. Whereas Bush broadcast his good news from the Cabinet Room of the White House, Obama announced the death of Osama bin Laden from behind a podium demarcated with the presidential seal in the East Room. The latter setting deserves a great deal more explication than the Cabinet Room, as it enjoys a rich history and has been repurposed to serve numerous extraordinarily different occasions since its conception.

According to historians from the White House Historical Association, the East Room was designed by George Washington and White House architect, James Hoban, to be the largest of the State Rooms in the White House, and it was to be called the "Public Audience Room" (White House Historical Association, n.d.). Despite its intended regal purpose, the East Room was ultimately one of the last rooms finished in the construction and design of the American White House. For years, it served as the utility room for the Adams family, as a place for First Lady Abigail Adams to hang her laundry to dry. After the great White House fire in 1814, the building was redesigned by Hoban, and the East Room was reconstructed (and left unfinished) once more. 
Among a host of other things, President Andrew Jackson lives on in infamy as the president responsible for finishing the interior of this State Room—and is responsible for the East Room's memorable style, including intricate panels lining the walls (although his original vision contained bright yellow wallpaper speckled with stars), extravagant carpets spread across the floor, several sparkling chandlers dominating the equally ornate ceiling and drawing attention away from the gaudy curtains draped across great windows (White House Historical Association, n.d.). Since Jackson's time in office, the East Room has undergone several changes with each passing presidential administration.

Despite each administration's efforts to make the space their own, there was no question - the East Room was meant to entertain crowds. In 1862, the Lincoln family famously hosted the "Grand Presidential Party," an evening ball intended to flaunt newly finished renovations to the White House, for a crowd of hundreds in the East Room (Smithsonian Institution, 2020). Before his daughter's wedding in the East Room, President Grant renovated the space again to better suit the occasion — adding looming mirrors above the many fireplaces in the space and replacing the classic glass chandeliers with chandeliers adorned with modern glass globes (The New York Herald, 1874). Over the course of centuries, the room has also hosted several renowned musicians at its grand piano, presented to the White House by Steinway and Sons in 1903. Peformances in the East Room are hardly limited to piano recitals, however, as performances have since ranged from operas and ballets to jazz concerts in the East Room (White House Historical Association, n.d.). In 2009, Broadway icon, Lin Manuel Miranda, debuted the song, "Alexander Hamilton" from his musical, Hamilton, before a large audience during the "White House Evening of Poetry, Music, and the Spoken Word." That evening, filled with spoken word masterpieces and the works of artists like James Earl Jones (Lee, 2009), must 
be remembered in context alongside the other ways in which the East Room has been used to entertain the American public.

I employ "entertain" here in an entirely new way, as it refers to the act of hosting visitors rather than the act of amusing or distracting. In this contrasting context, visitors to the East Room mourned the loss of American figureheads, rather than celebrating with song and dance and nuptials. Not unlike the Rotunda of the U.S. Capitol which occasionally hosts American leaders lain in state, the East Room of the White House has hosted funeral services for lost leaders like Presidents William Henry Harrison, John F. Kennedy, and Abraham Lincoln (John F. Kennedy Presidential Library and Museum, 2019; White House Historical Association, n.d.). Three years prior to President Lincoln's untimely demise, he also mourned the loss of his own son, Willie, in the same spot. In times of mourning, with the curtains drawn closed, a new tone inevitably fills the room like a heavy fog.

Gone are the joyful notes of partiers and festivities - replaced with an air of decorum and solemnity. In 2011, Americans were forced to reckon with a new repurposing of the East Room, as it entertained a new audience led by President Obama to memorialize the assassination of Osama bin Laden. I can only imagine that the walls of that space were filled with a new, yet familiar combination of pomp and circumstance tinged with the formality of an inhumation.

As I recall Obama's (2011) speech, perhaps the most impressive part of Obama's delivery began well before he approached the microphone. I am referring, of course, to the walk across a long red carpet which led to the spot behind the podium. We see such red carpets elsewhere in our daily lives, although many of us have probably not been so fortunate to enjoy a walk across the red carpet ourselves. For example, a similar red carpet lines the steps presidents climb entering and exiting Air Force One, and it reminds bystanders of the importance of the 
American presidency. Its appearance behind Obama also invokes images of celebrities traversing red carpets at award ceremonies, taking the most important strides of their careers—each moment captured for eternity by the flashbulbs of glamour magazines. It reminded me, as well, of the red swaths laid before foreign dignitaries to emphasize their importance and cushion their steps. In each reiteration, that carpet operates as a reminder that the men and women who step upon it are inherently set apart and a step above the rest of us. Therefore, it was an interesting choice to feature in the carefully constructed shot of the president delivering such a momentous address regarding the death of any man.

Accordingly, before Obama even uttered the "good evening" which started his speech, American exceptionalism was woven into its backdrop. Adding to atmosphere of patriotism in the East Room that evening, stood a flag on either side of the podium, just in front of Obama. Although most news agencies cropped the flags out of frame and focused instead on the president, an American flag sat at Obama's right side (for example, see Baker, Cooper, \& Mazzetti, 2011; NBC News, 2016; Rosen, 2011). Over his left shoulder, the dark blue flag with the presidential seal displayed both the olive branch and the quiver of arrows held in the eagle's talons. Even if we set aside the flags and carpet, opting instead to focus on the impressive marble columns trailing behind the president or on the crystal chandeliers twinkling in the bright lights set up by the news networks, the majesty of the American presidency was on display around midnight that evening.

The attack on bin Laden's base, a small and unstately “compound in Abbottabad, Pakistan" (Obama, 2011, para. 10), transpired hours before Obama began his address at 11:35 PM EST. Although the Obama administration allegedly contemplated "the possibility of holding off on an official announcement,... reports of a helicopter crash in Abbottabad were already 
starting to pop up on the internet" (Obama, 2020, p. 696). The crash of one of the Navy SEAL teams' helicopters served as a clue for internet sleuths-allowing folks to connect the dots between the crash, American boots on the ground, and the assumed inhabitant of the compound. And so, the Obama administration's hand was forced. Within several hours, a speech was turned around and word was leaked officially to the press: "we got him" (Obama, 2020, p. 695). The president's expression of celebratory relief immediately following his own realization that bin Laden was dead echoed the words of Bremer eight years earlier (The New York Times, 2003). By midnight, every network in America was prepared to broadcast live the president's remarks formally confirming what we all knew to be true. The nightmare was over. The villain in this narrative was defeated. And we could finally rest easily and wake comfortably, because the wicked witch, bin Laden, was dead.

From September 11, 2001 onward, "Osama bin Laden" was a household name in the United States, although some already knew of him from his earlier attacks on the World Trade Center back in 1993 (Bureau of Diplomatic Security, 2019). bin Laden's connection to al Qaeda—as the terrorist ring's ringleader and founder-was well-known. But more impactfully still, I believe most Americans' first association upon hearing his name was and probably is still our memories of $9 / 11$. We understand him in one vein, and in one vein only: as a villainous terrorist. This association is rightfully earned. Our worldviews shattered that day as we watched buildings collapse inward, as we began to contemplate whether jets could even do that much damage to a building, as we wrestled with our own senses of mortality and came to terms with the largest loss of life due to terrorism we ever experienced. That destruction was planned. Every death was intended. Every bit of the devastation we felt was masterminded by bin Laden, and in 
the nearly ten years that elapsed between 9/11 and the end of bin Laden's life, Americans had not forgotten.

And of course, the president had not forgotten.

"Good evening," Obama began. "Tonight, I can report to the American people and to the world that the United States has conducted an operation that killed Osama bin Laden, the leader of al Qaeda, and a terrorist who's responsible for the murder of thousands of innocent men, women, and children" (Obama, 2011, para. 1). From the very start of his address, Obama made painstakingly apparent his intentions behind the attack on the Pakistani compound. This was an act of retribution against the murderer and terrorist with gallons upon gallons of American blood on his hands. Later in his speech, the president continues to reinforce the connection between bin Laden and his status as the villain of the story:

The 9/11 attacks were carried out by al Qaeda — an organization headed by Osama bin Laden, which had openly declared war on the United States and was committed to killing innocents in our country and around the globe. And so we went to war against al Qaeda to protect our citizens, our friends, and our allies. (Obama, 2011)

This passage marks the first of many in this speech that separate bin Laden and his comrades from Americans and our allies. It separates the villains from the heroes and the innocent. Without question, the implied heroes in this context are the Americans who swooped in (yet again) to save the day, and rid the world of another big, bad terrorist threat. Understanding or identifying the "innocents" Obama mentions is a much more challenging task, and it is one we will examine more later.

Regardless of who the innocent bystanders or victims are in this instance, the heroic actors in this story exemplify American interventionism. Boiled down to its innermost roots, the 
decision made by Obama's predecessor to go to war with al Qaeda was made in reaction to the attacks of September 11. In the absence of other international actors responding in what Americans deemed a proportional response to those attacks, Bush launched the War on Terror to show the rest of the world how it is done. Americans acted with the might of American exceptionalism and exemplarism to intervene on behalf of our own citizens, and as Obama argued, "to protect... our friends and our allies" (Obama, 2011, para. 6).

Later still, the president makes the distinction between al Qaeda — a terrorist group comprised of fundamental Islamic terrorists - and Islam, making clear that his and Americans' wrath should not be directed at the religion or its believers. The villains of this story are not peaceful Muslims. The villains are instead the individuals driven to kill for their beliefs:

We must also reaffirm that the United States is not - and never will be - at war with Islam. I've made clear, just as President Bush did shortly after 9/11, that our war is not against Islam. bin Laden was not a Muslim leader; he was a mass murderer of Muslims. Indeed al Qaeda has slaughtered scores of Muslims in many countries, including our own. So his demise should be welcomed by all who believe in peace and human dignity. (Obama, 2011)

In this passage, Obama offers a clearer depiction of to whom he refers when talking about "innocents." Here, we can glean that the president lumps all victims (who are unaffiliated with al Qaeda or its members) of al Qaeda attacks together as innocents. Certainly, this group of "innocents" includes American civilians lost on September 11, 2001. But it also includes the first responders to the scene, the family members grieving the loss of or irreparable injury to loved ones. Most importantly in this speech, it includes the victims of attacks besides the one carried out on September 11, 2001. In this latter category, we must stretch our purview to consider the 
terrorist attacks with which we are not quite as familiar - the bombings in town squares, the selfdetonations on sidewalks, the explosions of cars with roadside weapons, the merciless shootings and mutilations of Middle Eastern civilians and citizens of nations around the world. Included in that group of innocents affected or assassinated in the wake of al Qaeda's wrath are similarly the families and folks who lost loved ones to bin Laden's unique brand of terrorism.

It was benevolently on behalf of all these innocents that Obama intervened. It was in the best interests of Americans and of all these other innocents that Obama acted as a presidential patriarch—just like his predecessor, Bush. Unlike Bush, who was thrust into a mess of terrorism following 9/11, Obama was elected by a populace who had every opportunity to learn about his desire to eradicate bin Laden as a threat capable of ever harming another human life again. Shortly after $9 / 11$, Obama began advocating this position, and made it a theme in every subsequent election campaign on his way to the White House (Holland, 2007; McFarlane, 2016; Obama, 2020; Schmidle, 2011). He was elected even after making clear his intentions regarding al Qaeda and bin Laden. In some ways, the votes he received on Tuesday, November 4, 2008 may have offered all the justification needed to fairly claim he was acting in America's best interests when he pursued an attack against bin Laden. Obama actually reiterated this sentiment when he said,

I've repeatedly made clear that we would take action within Pakistan if we knew where bin Laden was. That is what we've done. But it's important to note that our counterterrorism cooperation with Pakistan helped lead us to bin Laden and the compound where he was hiding. Indeed, bin Laden had declared war against Pakistan as well, and ordered attacks against the Pakistani people. (Obama, 2011) 
Once more, Obama expounded upon the first-person pronoun, "us," used to identify heroes and allies that made the mission against bin Laden possible. At this point, "us," is not just limited to the Americans responsible for planning and enacting the mission, nor is it limited to American citizens overall, as "us" is often utilized by American presidents. Rather, "us" refers to the innocents affected by the villains in al Qaeda and bin Laden, the organization's leader. This inclusion is demonstrated by Obama's (2011) statement, “[bin Laden's] death does not mark the end of our effort. There's no doubt that al Qaeda will continue to pursue attacks against us" (para. 12). There is clear pitting of a virtuous "us" against a nefarious "them."

Even though "their" leader was taken out by an American SEAL team just hours before the start of this speech, Obama understood that bin Laden's death was not a magical cure for the immorality of terrorists in al Qaeda. Without their leader, the organization's members would not likely run home with their tails tucked between their legs. They would not be deterred by American intervention. If anything, "our" intervention and decision to assassinate their leader might only serve to further solidify their hatred for Americans and the American way of life. Therefore, "our" fight continues.

That said, there stands proudly at the forefront of "us," the members of the Navy SEAL team ultimately responsible for killing bin Laden. Those actors are the true heroes of the day. They acted in a similar fashion to the passengers of Flight 93 on September 11, 2001, whom Obama (2011) commends for preventing "even more heartbreak and destruction" (para. 2). The SEALs' brave actions ten years later took out an evil mastermind who would surely have dealt more destruction around the world if left alive. The president took care to note the heroism of the SEAL team members and lavish compliments upon them when he said, 
The United States launched a targeted operation against that compound in Abbottabad, Pakistan. A small team of Americans carried out the operation with extraordinary courage and capability. No Americans were harmed. They took care to avoid civilian casualties. After a firefight, they killed Osama bin Laden and took custody of his body. (Obama, 2011)

Though gracious, the forty-fourth president was far more reserved than the forty-third in his administration of compliments to and for the individuals immediately responsible for eliminating an active terrorist threat. While Bush (2003) reveled in his ovation for the "military forces" by describing them as "superb" and "brave" and "skill[ed]" and "precise" (para. 5), Obama (2011) placed his emphasis on relaying the courageous actions made with utmost precision by the Navy SEALs.

In their efforts to penetrate the bin Laden compound, not one American life was lost. The announcement was not quite as impressive as Bush's — in which the former president could announce that Americans captured Hussein alive and could therefore interrogate him before passing the terrorist off to the Iraqi government for prosecution. It was unfortunate that Obama could not claim a perfect victory, since bin Laden was killed in the raid. bin Laden could not offer Americans any information or improve intelligence regarding terrorist activities planned by al Qaeda or in the Middle East overall. With that loss in mind, bin Laden's death was still a certain and unqualified victory for Americans.

The news of bin Laden's assassination prompted a series of celebratory magazine covers and headlines. bin Laden joined the likes of Adolf Hitler and Saddam Hussein on the cover of Time Magazine's May 20, 2011 issue (Rothman, 2017). With the dripping red "X" over his face, 
Time made their satisfaction known to the world - another evil villain is gone. He cannot hurt us anymore.

Several local periodicals made less of an attempt to veil their enthusiasm. Minneapolis's Star Tribune printed a headline and photo that occupied over half of the front page. "BIN LADEN IS DEAD" was typed in a font nearly twice the size of the Star Tribune's title, and beneath the title laid an image of people in the street with their arms raised and mouths gapingevidently thrilled at the news that the man haunting their nightmares and memories was slain. In the foreground, spectators can practically hear the words, "we won," flow from the mouth of a man with an American flag draped around his shoulders (The Toledo Blade, 2011).

At about this point, I should probably reveal another facet of my identity. I am not familiar with sports. My students often tease me because I call all sports "sportsball," whether there is a ball involved or not. Hockey? Sportsball. Tennis? Sportsball. Rugby? Sure, it can be sportsball too. I am far too uncoordinated to play any sportsball game. And in high school gym class, I could only ever be counted on to drop the ball or hurt someone in my gallant efforts to end my time in possession of the ball as quickly as was humanly possible. However, although I am not the most knowledgeable when it comes to matters of athleticism, I know one thing is true across the board... winners take home trophies. Winners take home trophies as evidence of their victories, so that they can return to their neighbors and friends and families, with flags around their shoulders and their fists held high, knuckles wrapped tight around a hard-earned symbol of their victory. Americans' victory in the manhunt for bin Laden was no exception-though I feel fairly confident there was no ball at play in this rendition of sportsball. And in this particularly high-stakes sportsball game, the trophy was a lifeless corpse - a corpse with which the Navy SEAL team left the compound as evidence of their victory. 
In Obama's (2011) own words, “they killed Osama bin Laden and took custody of his body" (para. 10). The most striking part of this sentence is the word, "custody." It can be interpreted in a couple of ways. First, I understood it in terms of objectification. bin Laden's body was, in this instance, an object to be taken. It could serve as a trophy for victors. Interestingly, bin Laden's body was not brought home. It never made it to the United States. Because in an effort to prevent acts of martyrdom or pilgrimage (as Jihadists would presumably have travelled to pay homage to their late hero (our conquered villain)), the Obama administration planned from the start to lay bin Laden to rest at sea. His corpse was given a traditional Muslim burial before soldiers tipped his body, wrapped and weighed down in a sealed body bag, overboard (Obama, 2020). In other words, the objectified trophy never made it home, and few eyes ever saw proof of such a trophy. That so few Americans could verify our villain's demise fanned the flames of conspiracy, and called into question the reliability of Obama's narration (Corbin, 2015; Mitchell, 2020). Moreover, that there was any room for the concoction of conspiracies surrounding this important event opened the Obama administration up to the possibility of their story being questioned. As such, to conspiracy theorists and doubters, the story did not retain its internal narrative coherence. Obama anticipated this response, and provided copious justifications of his actions and the journey to reach a final decision throughout the speech.

My second interpretation of "custody" implies a sense of paternalism once more, similar to Bush's position, because I often associate that word with custody battles fought out in courtrooms between divorced parents. In these legal fights, a judge must determine to which parent the responsibility of raising the children befalls. In the case of bin Laden's body, the United States operated as judge, jury, and executioner. But they did so paternally, supposedly 
with the best interests of American citizens and the rest of the world in mind. Since the president ordered the raid on bin Laden as a paternal actor, Americans are accordingly the responsible party. And then, I suppose, it is only right for Americans to win the responsibility of custody. In addition to the Navy SEALs directly responsible for shooting bin Laden, Obama also thanks other brave women and men enlisted in the United States military who helped progress the American War on Terror. Each of these individuals is quickly accounted for in the all encompassing first-person pronoun, "we":

Thanks to the tireless and heroic work of our military and counterterrorism [sic] professionals, we've made great strides... We've disrupted terrorist attacks and strengthened our homeland defense. In Afghanistan, we removed the Taliban government, which had given bin Laden and al Qaeda safe haven and support. And around the globe, we worked with our friends and allies to capture or kill scores of al Qaeda terrorists, including several who were a part of the 9/11 plot. (Obama, 2011, para. 6)

Repeatedly speaking in terms of "our" efforts, and addressing the American public as a collective "we," President Obama works to build unity. He reminds listeners that "we," as citizens of the great and exceptional United States of America, have done a whole lot in our efforts to quell terrorism in the Middle East. "We" dismantled a corrupt government and took out militant terrorists and accomplished it all using superior intelligence about our enemies. Moreover, "we" worked alongside our allies, sharing our exceptional information and demonstrating time and time again how we can be counted on to exemplify a proper response to terrorist threats. 
We are united in our fight against terrorists like Osama bin Laden. Before his death, we were united behind the capture of Sadam Hussein under the umbrella of the Bush administration. Before that, we were united in our response to the attacks of 9/11. Obama incorporates into his speech as a recurring theme that sense of unity we felt in a time of crisis just one decade earlier. The words he employs transport listeners back to that feeling and paint a painfully clear picture of the pain and fear we transformed into unity:

It was nearly 10 years ago that a bright September day was darkened by the worst attack on the American people in our history... hijacked planes cutting through a cloudless September sky; the Twin Towers collapsing to the ground; black smoke billowing up from the Pentagon; the wreckage of Flight 93 in Shanksville, Pennsylvania... And yet we know that the worst images are those that were unseen to the world. The empty seat at the dinner table. Children who were forced to grow up without their mother or their father. Parents who would never know the feeling of their child's embrace. Nearly 3,000 citizens taken from us, leaving a gaping hole in our hearts.

On September 11, 2001, in our time of grief, the American people came together. We offered our neighbors a hand, and we offered the wounded our blood. We reaffirmed our ties to each other, and our love of community and country. On that day, no matter where we came from, what God we prayed to, or what race or ethnicity we were, we were united as one American family.

We were also united in our resolve to protect our nation and to bring those who committed this vicious act to justice. (Obama, 2011, para. 2-5) As indicated by the words I underlined above, Obama repeatedly utilizes collective pronouns like "we" and "our" to force listeners together. He rhetorically invokes a sense of 
Americans coming together like a "family," united not by blood (though the donation of blood is mentioned), but by the traumatic experience we all experienced together. Even though we were the victims of a vicious attack, we were also heroes in our own rights. Our response to tragedy, Obama argues, is the thing that made us strong. Our unity is the thing that made us so exceptional, so steadfast, such an impenetrable force that no opposing foe would dare threaten us or the U.S. again.

In the introduction chapter to this thesis and throughout, I recalled my own memory of September 11, 2001. In this essay, remembering the events of that day serve to contextualize my analysis and rhetorically situate the claims I make. In a roundabout sort of way, these detailed recollections help me to build a story around my narrative analysis of these speechesconnecting one to the other to the other, since I will later argue that these stories are interconnected like episodes in a series. But just as I work to build a narrative through line in my analysis, Obama uses his own memories of 9/11 to start his story. I emphasize "story" here, because Obama's speech reads like a story. He delivers his speech as if it were a bedtime story. And as a proper narrative, his tale is replete with heroes and villains and themes and the resolution of conflict and a feel-good ending (Rowland, 2009).

In the extended passage above, Obama's rich imagery takes us right back to the people we were on September 11, 2001. It forced us to feel all the feelings we felt that day. We felt the overwhelm of the moment in the consonance and repetition of the harsh consonant "ck" sounds in "hijacked planes cutting through a cloudless September sky." Moreover, we felt again the redhot rage and fear we felt in the metaphor of "the images of 9/11 sear[ing] into our national memory" (Obama, 2011, para. 2). Like we were all burned by one big brand, those feelings have scarred us permanently, and they are not going anywhere anytime soon. Each subtle rhetorical 
device utilized in this speech by Obama serves as evidence of his mastery over pathos. That Aristotelian appeal makes Obama's speech that much more impactful, since we were all emotionally invested in his words - in the news of our greatest enemy's death.

For those of us that may have been too young or not paying attention (although taking the position of the latter is frankly beyond my understanding), Obama's decision to relive the events and aftermath of the attack help to justify his decision to go after bin Laden. To that end, Obama uses this eloquent and highly descriptive narrative to introduce the story he would go on to tell about how Americans made it to this point- to the point in which he opted to pursue assassination. Unlike Bush's (2003) comparatively short three minute address, Obama took his time (over the course of a nine minute speech) walking listeners through each step of his decision-making process and then each step that brought us closer to our end goal of ultimately killing the bad guy. Perhaps Bush did not need to provide as much justification, because his administration's bad guy was brought in alive. Perhaps Obama felt the need to offer these reminders because so much time had passed between September 2001 and May 2011. If nothing else, Obama's dedication to justifying his administration's decision to act offensively against Osama bin Laden contributed to his perception as a reliable narrator to voters on both sides of the political aisle.

The impact of this speech was intentional, though its success allegedly came as a surprise to the president, who wrote in his memoir about the address, "for the first and only time in my presidency, we didn't have to sell what we'd done. We didn't have to fend off Republican attacks or answer accusations from key constituencies" (Obama, 2020, p. 697). Like Bush, whose approval rating skyrocketed after the capture of Hussein, Obama enjoyed a similar lift of bipartisan support following his announcement (Dao \& Sussman, 2011). 
Just as we did under President Bush's leadership, Americans rallied around the flag (or in this case, the presidency). From our position in the stronghold of the American-isms, and protected by the good father we could see in our Commander-in-Chief, we felt a sense of strength and national unity. We were united in our pride, for we granted another tormented people a great gift when we eradicated bin Laden, their long-time tormenter. But above all else, we were united as American heroes in our victory against yet another common enemy.

Throughout his first three years in the White House, President Trump dealt with a previously unimaginably divided nation and a consistently stagnant favorability rating (Gallup, 2021). Therefore, having witnessed two presidents before him experience such spikes in their polling numbers following the assassination of known Middle Eastern terrorists, it is entirely possible that Trump ordered the assassination of Iranian General Qasem Soleimani to chase his own political boost. With that in mind, I will next address Trump's speech following that assassination. 


\section{CHAPTER VI: DONALD TRUMP AND THE}

\section{ASSASSINATION OF QASEM SOLEIMANI}

Within just a couple minutes of walking, visitors to Mar-a-Lago Club (hereby referred to simply as Mar-a-Lago) can sink their toes into the balmy sands of Palm Beach, Florida. They can swim along "the two most beautiful acres of direct access private beach anywhere on the East Coast" (The Mar-a-Lago Club, 2021, para. 1). Or they can swim in a massive private swimming pool directly off the beach, sipping on cocktails from the nearby, on-property beachfront bistro. Guests can enjoy countless relaxation opportunities without even leaving the resort's campus. Amenities include access to an exclusive luxury spa where guests can enjoy a lavish massage or facial. Alternatively, clients are primped and pampered in a private all-marble salon and have access to nail, hair, and makeup treatments from trained experts. A state-of-the-art fitness center offers Pilates and yoga classes hosted by professional trainers.

For folks interested in a more rugged, outdoorsy sort of workout, Mar-a-Lago does, of course, offer its members exclusive access to any of "five championship red-clay tennis courts," and staff will happily connect inexperienced members to trained coaches (The Mar-a-Lago Club, 2021, para. 1). Tennis is obviously not every magnate's game of choice. So for those folks who might prefer another outlet for their competitive nature or relaxation, the resort also offers guided games of bridge and a sprawling lawn reserved exclusively for games of croquet. Last but not least, the site is primarily known the world over for its proximity to expansive golf coursesincluding the private Trump International Golf Club. Unquestionably, the most famous member and frequent visitor of that golf club is the now former American president, Donald Trump. As of my writing this chapter, Mar-a-Lago is also now Trump's official residence (Haberman, 2019). He is not only a well-known member - the former president is also probably the member 
with the honor of generating the club the greatest sum of money of all its members, since he travels with a host of Secret Service agents who all require housing and accommodations during his stays (United States Government Accountability Office, 2019).

Information surrounding Mar-a-Lago or the Trump International Golf Club is challenging to come by given the exclusive nature of the resort and its clientele. However, after a rather awkward phone call to Mar-a-Lago (with a receptionist named Joelle, who preferred to keep her last name anonymous, and revealed that most callers are irate and that I was one of the nicest people she had spoken with all day), I learned that room rates range anywhere from $\$ 475$ to $\$ 1,500$ per night. I also confirmed that there is no public access to the resort. There are definitely no public tours. Rather, Joelle clarified that tours are only available to outsiders if they are invited and guided by an established Mar-a-Lago member (Joelle, personal communication, August 31, 2020).

The exclusivity of Mar-a-Lago differs greatly from the traditional expectation of the President's dwellings. Even though the White House is secured by levels upon levels of checks and barriers and armed guards and Secret Service members, public tours are still offered on a daily basis. Americans are welcomed to the White House, because it is, after all, their house. It is the People's House (Axios, 2014), occupied by the people's president—who should be so honored to reside there. And as we have already established in just two short reviews of rooms' histories, each nook and cranny of the White House has a rich and storied past that seeps into every action and address made from within its walls. Incredibly important and memorable speeches, not unlike the ones analyzed in the prior two chapters, have been delivered from inside those walls. But that precedent would not continue through the Trump administration. 
Instead, in the four years in which President Trump occupied the White House, Mar-aLago served as the setting for many key moments throughout Trump's political career. On several occasions, the president and first lady hosted Japanese Prime Minister Shinzo Abe and his wife at Mar-a-Lago (Smith, 2018). Tradition would hold that such occasions would usually transpire inside the White House. Trump, however, is not one to abide by traditions laid forth by former presidents—as Prime Minister Abe joined renowned company like Brazil's President Jair Bolsonaro, who also visited Trump at Mar-a-Lago (Rogers \& Baker, 2020). Over one thousand miles away from the security of the White House Situation Room, Trump was also briefed and made important decisions regarding a Syrian missile crisis in Mar-a-Lago just before grabbing a bite to eat with China's President Xi Jinping (Thévoz, 2021; Walcott \& Holland, 2017).

A gilded venue through and through with a $\$ 200,000$ induction fee (Cherelus, 2017), Mar-a-Lago is hardly the expected place for such impactful meetings. Of all the strange presidential events that have transpired at Trump's favorite resort, though, I argue that one event takes the cake for most-out-of-place at a beach resort. I am referring, of course, to his announcement on January 3, 2020, that a crew of American soldiers successfully assassinated Iranian General Qasem Soleimani.

Neither Joelle nor I are sure where or in which room in the massive resort the speech occurred, because a large blue curtain was pulled across any identifying characteristics in the space. But against that blue curtain laid the familiar American flag over Trump's right shoulder and the dark blue flag of the presidency over his left. Save for the entirely new venue, the scene looked incredibly similar to the speeches from Presidents Bush and Obama announcing the eradication of their own administrations' terrorist threats, right down to the presidential seal on the podium behind which Trump stood. Like Bush before him, it was painfully apparent that 
Trump intended to read his speech from teleprompters, because most news networks recorded the president emerging from behind the curtain in a wide angle that captured the transparent panels on either side of the podium.

I was out of school on winter break when this speech was delivered. And just a few days after the Christmas holiday, I remember I was sitting with my mother and father in our family home's living room watching the news. We were watching a program on MSNBC when a breaking news alert interrupted our show. President Trump entered the shot from stage left, materializing from behind the big blue curtain. My view seemed to be framed on either side by those teleprompters. A thrill of excitement and terror ran up my spine as I watched, breath bated, and I remember thinking: This must be important if he is going to read from a scripted speech! When it became clear Trump would read from a script, this speech moment felt extremely different from the president's many other speeches in which his proclivity for off-the-cuff and disorganized tirades reigned prominent.

Trump's eye contact with his audience and glances toward the camera were few and far between. For the most part, his head just swiveled from the left to the right as he read his message line for line. With that in mind, I am forced to repeat my analysis of Bush's delivery seventeen years before Trump's speech... As his eyes darted from one end of the teleprompter to the other, viewers were reminded of the fastidiousness of this speech. I include this statement again here because as Cicero outlined in his fifth canon, pronuntiatio, delivery enables rhetoricians like myself to expand their purview from words on the page to an analysis of the speaker's verbal and nonverbal delivery. In this case, a mere textual analysis would not have sufficed, because viewers' perception of Trump's delivery in this regard deeply impacted the way they received and perceived the speech. My own perception of the speech and how 
presidential Trump seemed in the moment was directly tied to my observation that he read from

a teleprompter - that he understood how important this speech was not only in the United States, but abroad as well.

As the news would later report, with coverage of mass demonstrations in the streets of Tehran, the Trump administration just took out a beloved Iranian leader (Naji, 2020). Therefore, the handling of the announcement to both the American people and the world required delicacy. It required careful attention to details and the kind of precision that is not often associated with Trump's speeches. It practically demanded a teleprompter-driven speech from Trump.

That said, this speech was not nearly as eloquent and verbose as the other two speeches I analyzed in previous chapters. At times, it was clunky and challenging to follow. The parts that stood out to me were Trump's justifications for killing Soleimani. I underlined these passages with a red marker on my annotated copies of the speeches. For the most part, Bush's and Obama's speeches had blocks of red at the start of their speeches (when they reminded audience members of the terrorists' transgressions) and at the end (when they attempted to tie up loose ends, leaving no doubt in listeners' minds that the right action was the action taken by eliminating terrorist threats). In my annotated copy of Trump's speech, nearly every other paragraph is highlighted in red. One such section might leave listeners with a mild case of whiplash as Trump transitions from a paragraph of justification for his actions, to a line comforting Americans, back to justification for American intervention based on Soleimani's sinful misdeeds.

Soleimani made the death of innocent people his sick passion, contributing to terrorist plots as far away as New Delhi and London. 
Today we remember and honor the victims of Soleimani's many atrocities, and we take comfort in knowing that his reign of terror is over.

Soleimani has been perpetrating acts of terror to destabilize the Middle East for the last 20 years. (Trump, 2020, para. 8-10)

This passage is one of many justifications for Trump and his administration to assassinate the Iranian general.

But nowhere is the clear distinction between hero and villain, protagonist and antagonist, more apparent than in these three sentences. If we begin with the first line, I find it nearly impossible not to feel some rage percolating in my stomach. The line, "sick passion," in relation to "the death of innocent people," is vile, abhorrent, despicable. When I hear "sick passion," my mind jumps to the dark world of fetishized obsessions. I then assume that Soleimani's behaviors are comparable to the twisted nature of serial killers and masochists who find satisfaction in the suffering of others - particularly those most vulnerable and weakest members of our society. In this case, Trump (2020) proposes that Soleimani gleans that satisfaction from harming “innocent[s]" (para. 8). If Iranian innocents and their innocence are his target—or if American innocents or innocence are his target—we can safely assume that Soleimani is a villain by contrast. Soleimani is an evil, evil man.

That association from villain to Soleimani to evil happens quickly. In an instant, the speech forces listeners to process the label and quickly sort Soleimani in their mental filing cabinets in the folder marked "bad guys." In a matter of moments, we process our understanding of Soleimani through the lens of our post-9/11 traumatized, yet American exceptionalism-laden, frames of reference. The memory of this story's villain irrevocably resides next to the likes of the Big Bad Wolf, every evil stepmother in a Disney film, Adolf Hitler, Saddam Hussein, and 
Osama bin Laden. It is important for us to acknowledge the categorization of Soleimani alongside other notorious villains because Trump's association between Soleimani and villainy works in several key ways in this speech.

For starters, it plainly evokes a pathos response in American audience members (and perhaps residents of other nations), because the world is now inhabited by one fewer evil person as a direct result of American action. But Trump's hyperbolic demonization of Soleimani also magnifies the self-congratulatory praise the president doles upon himself in the speech. Despite acquiescing partial credit to the military operatives directly responsible for carrying out the attack against Soleimani, the way Trump relays the story makes him out to be the ultimate hero of the hour. In that regard, Trump prevails as a pro-military hero, because even though Trump opted out of military service each time his number was called (and therefore never served his country a day in his life before being elected as the American Commander-in-Chief (Shane, 2019)), it was evident in this speech and action against Soleimani that Trump understood the value of the armed forces in foreign affairs. To his overwhelmingly pro-military base of supporters, this was an important position to clarify as Trump rang in the new year and segued into another yearlong election season. Perhaps most importantly, Trump necessarily had to exaggerate Soleimani’s turpitude. Because unlike Hussein or bin Laden before him, few Americans had ever heard Soleimani's name — and they certainly did not know of Soleimani's track record. Therefore, if Trump did not hyperbolize Soleimani's wickedness in his justification for assassination of the Iranian general, the president ran the risk that his predecessor's announcement of bin Laden's death would overshadow his own announcement.

Trump (2020) further solidifies this perception by clarifying the reach of Soleimani's depravity. It extends all the way from "New Delhi [to] London" (para. 8). According to a quick 
search on Google Maps, traveling from Point A to Point B would traverse a staggering 4,867 miles if the journey is made without crossing oceans. Importantly though, the quickest path from India to England does not cross the United States, which prompts me to believe that Trump is suggesting a path that would cut through his homeland in the United States, traipsing over both the Pacific and Atlantic Oceans. If this understanding of the expansiveness of Soleimani's reach is accurate, then Trump is alleging that Soleimani wielded greater power and influence over a larger terrain than any other leader (villainous or virtuous) in modern history.

But that reign of quite literal terror is tempered when, in the subsequent line of justification, Trump stated that Soleimani's main focus was on terrorizing and destabilizing the Middle East. Even in this re-interpretation, Soleimani's villainous tendencies stretched across a period of two decades according to Trump. His malice need not traverse open oceans if it is to be understood temporally. According to Trump's announcement, Soleimani exercised terrorizing power for nearly as many years as I have been alive.

Both interpretations are terrifying, whether we understand the far reach of Soleimani's terrorism in terms of years or miles. Both evoke strong emotional responses rooted in fear, for if Soleimani could inflict terror on such a large scale, then surely he could have been capable of inflicting terror in the United States as well. In addition to the pathos at work in his justifications, Trump's news of the Iranian general's passing left many Americans scratching our heads wondering, who is that? And why did we just kill him?

Unlike the reception of the presidential speeches announcing the abduction or annihilation of first Saddam Hussein and then Osama bin Laden, few Americans recognized the name, Qasem Soleimani, since it was not a household name. Although he may have been a bad, bad man to many, many Iranians and Middle Easterners overall, Soleimani was not an American 
menace. He did not topple the World Trade Center. By all accounts, he did not pursue any weapons of mass destruction. It is not even clear that Soleimani masterminded any direct attacks against American territories. If he was a menace to any nation or any peoples, it slipped under the radar of most Americans, whose attentions are rarely directed outside our borders (Council on Foreign Relations, 2019). With that in mind and before Trump could reasonably justify his administration's actions against Qasem Soleimani, he had to first introduce the American public to the target of his animosity. He had to answer the oft-asked question, who was Soleimani?

Besides his "sick passion," Trump identified Soleimani as the "number-one terrorist anywhere in the world" and the leader of "the Islamic Revolutionary Guard Corps and its ruthless Quds Force" (Trump, 2020, para. 6). Additionally, Trump spent a sizable portion of his four-minute address explaining who Soleimani was, and why the American people (and citizens of Iran and Iraq) should be grateful to Trump for expediting Soleimani's expiration date. As Trump himself declares,

Soleimani was plotting imminent and sinister attacks on American diplomats and military personnel, but we caught him in the act and terminated him.... For years, the Islamic Revolutionary Guard Corps and its ruthless Quds Force—under Soleimani’s leadership— has targeted, injured, and murdered hundreds of American civilians and servicemen... The recent attacks on U.S. targets in Iraq, including rocket strikes that killed an American and injured four American servicemen very badly, as well as a violent assault on our embassy in Baghdad, were carried out at the direction of Soleimani... the brutal repression of protestors in Iran, where more than a thousand innocent civilians were tortured and killed by their own government. (Trump, 2020, para. 4-11) 
Thus, though Soleimani was a person of relative obscurity to many Americans, Trump articulates how the Iranian general was a sort of wizard behind the curtain, calling the shots, and operating as a scourge on the planet.

In contrast to the justifications offered by Bush and Obama for their respective efforts to capture and kill Hussein and bin Laden, Trump's justifications pale in comparison. To be clear, I do not mean to minimize or in any way detract from the horrible impact of terrorism. The loss of life and sense of security due to the actions of known terrorist actions around the world is absolutely astronomical and downright devastating. However, the impact of Soleimani's actions were practically invisible to Americans, when compared to someone like bin Laden who knowingly conspired to and successfully murdered thousands of innocent Americans on American soil.

When Trump spoke of the one American recently killed, he was most likely addressing an attack approximately a week before his speech, because Soleimani's assassination occurred after a series of firefights between U.S. forces and Middle Eastern fighters in Iraq and Iran. On December 27, 2019, one American contractor died, and several other service members were wounded in a rocket attack to an air base near Kirkuk, Iraq (Barnes, 2019a). As the smoke cleared and the wounded were attended to, it was not immediately clear who was responsible for the attack. Nevertheless, the United States retaliated by targeting five locations across Iraq and Syria they knew to be occupied by Iranian paramilitary organizations, killing at least two dozen and gravely injuring some fifty others in the attacks (Barnes, 2019b). We retaliated for the death of an American, but was our attack justified? Were the deaths of 24 proportional to the loss of one American? According to the premise of American exceptionalism, that singular American life is worth far more than the lives of practically everyone else, because Americans exist on a 
pedestal miles above the other nations of the world. But if we broaden our scope to address the hundreds of Americans Trump claims were targeted or hurt or killed at the orders of Soleimani, were the deaths of American servicemen worth the potential of continued conflict in Iran? Did the death of Americans enlisted in the military or serving as civilian military contractors warrant the assassination of Soleimani just a few short days later? How could those casualties possibly measure up to the deaths of innocent civilians in an office building thousands of miles away?

I am not entirely sure they can be compared. Accordingly, even if we look only at the imminent threats to which Trump refers in his speech, I do not believe they were comparable to the looming threats from Hussein. At the point of Hussein's capture, his was a household name. We were already engaged in armed conflict in Iraq. Most Americans were already petrified at the prospect of weapons of mass destruction. And even though no such weapons were ever found, that threat was at least substantiated since Hussein used weapons of mass destruction in his past conflict with Iran and even against his own people (Bureau of Public Affairs, 2003). The threat was fleshed out. The threat was that weapons of mass destruction existed. Conversely, Trump did not identify the "imminent and sinister attacks" that Soleimani allegedly planned against the United States, and I do not particularly care to speculate about what those imminent threats might have been.

It would have been one thing to claim the assassination of Soleimani was a gift to the terrorized people of Iran—like Bush claimed when his administration captured Hussein. If such an effort was made by Trump or his speech writers, the whole assassination could have been written off as an act of paternalism. A crafty public relations team could have framed Soleimani's assassination as an act of benevolence for those immediately terrorized by Soleimani. 
But for the most part, that was not the case. The closest Trump came to making a paternalistic case for his intervention in the region was when he said, "the future belongs to the people of Iran — those who seek peaceful coexistence and cooperation—not the terrorist warlords who plunder their nation to finance bloodshed" (Trump, 2020, para. 14). In this claim, the first clause works to make a case for compassionate paternalism. Trump was just looking out for the people of Iran by taking steps to do what was best for them. In the second clause, Trump undermines any good work that might have been done by the first clause, because the entire episode now reads as a threat or warning to anyone looking to follow in Soleimani's footsteps.

One way or another, the establishment of an antagonist in the narrative encapsulating Soleimani's death falls in line with my analysis of the other presidential speeches declaring the elimination of a terrorist threat. But it is not the only similarity. There are many other parallels that can be drawn between Trump's speech and the addresses of his predecessors. To begin, there were bountiful examples of the American-isms from which I could choose to analyze in his four-minute speech. Unsurprisingly, the one that dominated the majority of Trump's speech was American exceptionalism, through his repeated references to the greatness of America—and of his own presidency.

Throughout his campaign, Trump promised to "make America great again." The phrase was and is still (even after his electoral expulsion from office on November 3, 2020) recognizable — plastered across ball caps and t-shirts, flags and even the rooftops of rural buildings. A select few supporters have even gone so far as to permanently tattoo the phrase onto their bodies (Rogers, 2018). And of course, the campaign slogan made a prominent appearance in Trump's first speech as president, wherein Trump made five variations of "we will make America [blank] again." In those five versions of the same statement in his inaugural address, 
Trump promised to restore American strength and prosperity and ensure the safety of the nation before concluding with a bold and resounding, "and yes, together we will make America great again" (Trump, 2017, para. 13). From the beginning of his time in the White House, this was the tone set by the president for the administration and for the nation over which he presided.

Just as the American electorate cast their votes for Obama with the knowledge that he intended to pursue bin Laden as soon as possible, nearly sixty-three million Americans cast their votes for a man they believed would restore American greatness to their country (Federal Election Commission, 2017). As such, it should have come as no surprise that part of Trump's justifications for pursuing Soleimani fell under the umbrella of his campaign promise to make America great and safe again.

Under his supervision, the American military was great, formidable, invincible. When given the go-order to launch the drone strike that killed Soleimani, "the United States military successfully executed a flawless precision strike" (Trump, 2020, para. 3). In other words, the women and men responsible for initiating the attack were not only "great," they were "successful." They were precise. Their work was "flawless." And in the hands of such an unstoppable military, foes of the American president should be wary. We need not read between the lines of his speech to reach that conclusion either, as Trump (2020) plainly makes the threat in his speech: "To terrorists who harm or intend to harm any American, we will find you; we will eliminate you" (para. 5).

The pronouns in this threat could not be clearer, where "we" apparently refers to the heroic (American) side of the still-ongoing (at least under the purview of the Trump administration) War on Terror. The second-person pronoun, "you," refers not to Soleimani, who is long dead by the time of this speech's delivery, but rather to anyone allied with Soleimani or 
to anyone or any organization that might have shared interests with Soleimani. "You" should be afraid, Trump reasons, because the American military—under the omnipotent eye of their Commander-in-Chief — is the greatest, mightiest, most exceptional military in all the lands: The United States has the best military by far, anywhere in the world. We have the best intelligence in the world. If Americans anywhere are threatened, we have all of those targets already fully identified, and I am ready and prepared to take whatever action is necessary. (Trump, 2020, para. 15)

This passage, which can be found near the tail-end of Trump's speech, demonstrates a habit I noted in my undergraduate thesis. Even though he is apparently talking about the greatness of the American military, it is also evident that he is referring to his own greatness.

Behind each "we" or "us" in Trump's speech, there lurks an implied "I" in the sentiment. The "we" encapsulates the United States of America, its citizens, its government, its oh-so-great military, and the president. It conveys a collective and collaborative effort to protect America. But that "we" does little to reverse the message ingrained in Trump's campaign slogan, in which a clear "I will" is assumed before "make America great again." For more than a year on the campaign trail, Americans were led to believe that they should vote for Trump because he (and he alone) was capable of accomplishing the restoration of greatness to the country. And the ghost of fulfillment of that vow was definitely present in the room when Trump slipped and said "I" instead of "we" in the above passage.

Yes, military experts may have programmed the drone strike against Soleimani, but lest we forget that they did so under Trump's orders. By this point in his presidency, Trump spent years positioning himself as the sole proprietor and provider of greatness in the United States of America. His ethos - his credibility as the only person in the entire country capable of "[making] 
America great again"-manifests itself in that prolonged effort. Trump's ethos is also demonstrated when he reminds his audience that he was able to assassinate Soleimani, whereas Bush and Obama did not even make an attempt to terminate that threat: "What the United States did yesterday [by killing Soleimani] should have been done long ago. A lot of lives would have been saved" (Trump, 2020, para. 10).

I struggled to determine how I should color that line in my annotations. It did not feel like an American-ism, per se, because it was not referring to the exceptionalism or interventionism of the entire nation. Rather, it referred only to the exceptional nature of one man, one citizen in a country comprised of millions and millions of other citizens. The argument could be made for the rhetorical device, synecdoche, at play here, since Trump is the part that represents the whole. Trump is America in this instance. Moreover, the line referred to the intervention into Iran under the guise of somehow making America greater or stronger or more feared by other nations around the world - and I am not entirely sure the latter can even be classified as exemplarism. Instead, this almost feels like a Trump-ism. Trump is the main hero in this story. Trump is the exceptional one. Trump is the only (paternal) one who knew what was best for the American people and for the world.

Somehow, in making these clarifications that he was the exceptional one in this scenario, Trump managed to also insult previous presidents and their administrations, because they should have had the wherewithal to assassinate Soleimani sooner. The nation would not have needed to wait for salvation from Soleimani, if only Bush or Obama would have taken the necessary steps to take out Soleimani before Trump's election. That distinction alone serves to situate this speech as an episode in a running series of speeches just like it—in the series I have taken to calling Exceptional Paternal American Heroes Triumph Over Big Bad Terrorists. Trump's speech, 
delivered seventeen years and three presidential administrations after Bush's speech announcing the capture of Saddam Hussein, is unquestionably shaded by the work of the previous presidential administrations. If that distinction does not make clear enough the relationship between Trump's speech compared to Obama's and Bush's speeches before him, then the prevalence of the American-isms and similar themes should make that argument as well. However, there are more similarities and even a few differences left to explore in the episodic relationships between these speeches in the overarching storyline. In the next chapter, I will work to tie up those loose ends, as well as present a unified picture of what implications these speeches might have for American identity and the future of American presidential elections. 
CHAPTER VII: CONCLUSION

\section{Presidential Setting, Presidential Man}

I opened the last three chapters with an analysis of the settings in which each of these three speeches were delivered. In 2003, President Bush announced the capture of Saddam Hussein from within the Cabinet Room of the White House. Eight years later, President Obama announced the assassination of Osama bin Laden within the storied walls of the White House's East Room in 2011. For Bush and Obama, the ground upon which they stood to declare their momentous news was laden with presidential precedent. Presidential things transpire in the White House every day. Important conversations and events are hosted in the East Room and Cabinet Room. Heads of state are welcomed. Democratic and diplomatic deals are brokered. Relationships valuable to the United States of America form and flourish. In those rooms, important decisions are made. And from behind a podium bedecked with the presidential seal in so many rooms in the White House, game-changing speeches are delivered. Though the content of Bush's and Obama's speeches were surprising (after all, who could truly have anticipated the exact timing that word would break of a hugely influential terrorist's eradication from the international playing field?), that they occurred where they occurred was not a surprise. The spaces themselves were presidential, and as such, only served to amplify the air of presidentiality of the men who made their announcements in those rooms.

As a matter of personal preference, I did not hold President Bush with high regard—even at the ripe age of six years old, which I was at the time of this speech's delivery. As a six-yearold, my political viewpoint was almost entirely formed by my parents' political ideologies. Of note in this arena, my mother was a fifth-grade teacher at a low-income school in Westville, IL, where the majority of her students were given free or reduced lunches to help parents make ends 
meet. As such, she resented Bush for the role he and his administration played in the implementation of "No Child Left Behind." In her classroom, she found that the program and his administration's view of standardized testing were both discriminatory against and very harmful for many of her students - particularly English language learners and students who were already falling behind in the curriculum (Crawford, 2004; Strauss, 2012). Moreover, President Bush was (and is) a Republican and therefore fundamentally disagreed with my mother on any number of social issues (Mica Carnahan-Freeman, personal communication, March 24, 2021).

Her perspective on the president of my childhood colored my adult perspective of Bush. And still to this day, a sour taste fills my mouth at the mention of his name. Even with that sour taste though, I can recognize how presidential Bush sounded in his address to the nation commemorating the capture of Saddam Hussein. I can recall how comforted I felt with the simple phrase, "the former dictator of Iraq will face the justice he denied to millions" (Bush, 2003, para. 1). This speech about providing justice to Iraqis (who experienced decades of torment under Hussein's malevolent thumb) and Americans (who lived in fear of his twisted brand of terrorism) felt like the morning sun rising after years of night terrors, visions of Hussein's scraggly beard flitting in and out of my frightened and frightening dreams.

Similarly, Obama's speech following Osama bin Laden's death exuded a sense of presidentiality. President Obama took his role and responsibility in that moment so seriously that practically every word of the speech dripped with cautiousness. He and his team of speech writers wanted to make sure that if nothing else, they got this one speech right. Therefore, he took the time to explain a Cliffs Notes version of the story leading up to bin Laden's assassination. In the narration of historical events leading to Obama's presence in the East Room that evening, he noted primarily the highlights, but took special care to rehash the pain and 
trauma many of us felt ten years prior as a sort of justification for his administration's actions against bin Laden.

In so doing, Obama also clarified for American listeners (as well as any audience members from other nations) that he did not consider war lightly. "After nearly 10 years of service, struggle, and sacrifice, we know well the costs of war," he said. "These efforts weigh on me every time I, as Commander-in-Chief, have to sign a letter to a family that has lost a loved one, or look into the eyes of a service member who's been gravely wounded" (Obama, 2011, para. 16). There are several pieces of this quotation alone that deserve unpacking.

For starters, Obama employs pathos here in full swing when he seeks to elicit an emotional response from his audience, as he describes the emotional turmoil and sense of responsibility he feels each time he has to contact a grieving family or hurting soldier. Moreover, the passage highlights the "good character... [and] good will" components of Obama's ethos (Hill, 2009, p. 44). When I refer to these two parts of the Aristotelian appeal, ethos, I am making the case for Obama's benevolence, as perceived by audience members. The passage showcases a kind, caring, and essentially good president who earnestly wants what is best for his country, and wants nothing more than for service members to return home unscathed. He does not want to make what I imagine are incredibly difficult, awkward, and regrettable phone calls home to the loved ones of the fallen. In addition to the pathos and ethos appeals working overtime in Obama's speech, the alliterative repetition of the harsh consonant "s" sound (underlined above) serves to amplify the pain in the president's voice. The alliteration also builds, "service" upon "struggle" upon "sacrifice," to emphasize the fact that Obama did not enjoy this part of his job. That all these deaths and hardships ultimately rest on his shoulders as Commander-in-Chief weigh heavily on him. 
Obama further solidified my perception of him in this speech as thoroughly presidential when he spoke to the defense of his nation: "We will never tolerate our security being threatened, nor stand idly by when our people have been killed. We will be relentless in defense of our citizens and our friends and allies" (Obama, 2011, para. 17). Perhaps most evident in these lines—behind the thick veil of presidentiality — was an underlying sense of paternalism. The reminder that Obama wanted what was best for his constituents and country cemented my perception of him as a trustworthy president with virtuous character.

Bush (2003) expressed a similar sentiment when at several points in his speech, he reminded audience members that he acted on behalf of the American people. In reference to Hussein and terrorists writ large, Bush (2003) said, "Such men are a direct threat to the American people and they will be defeated" (para. 6). Here, Bush implies that he (and the mighty American military) will be the ones to intervene and protect Americans in the face of villains like Hussein. In its paternalism, both presidents' reiterations of American exceptionalism (that the American military and its president are unquestionably great and will protect American citizens and citizens of the world at all costs) also paved the way for Trump to later justify his decision to kill as direct retribution for the loss of one American life.

Unlike Obama and Bush before him, Trump took a different route to deliver the news that "at [his] direction, the United States military successfully executed a flawless precision strike that killed the number-one terrorist anywhere in the world" (Trump, 2020, para. 3). The language in this statement is clunky, and left me asking several questions about whether or not Trump is lauding Soleimani's terrorizing efforts, since the label "number-one" is most often reserved for praise. For example, we often associate the label with phrases like "number-one movie in the world" as an application of the bandwagon fallacy to entice potential consumers to watch the 
film (Walt Disney Studios, 2019; Warner Bros. Pictures, 2013). In the absence of a motion picture to promote, is that label suggesting there should be a connection between Soleimani's assigned "number-one" status and American greatness? In other words, because Soleimani is the number-one terrorist, and Americans are responsible for killing Soleimani, are Americans then "number-one" by the powers of the transitive property? To compound this labelling train, if Trump represents the country over which he presides (according to the example of synecdoche explored in the last chapter), is Trump not ultimately the exceptional one in this equation?

Even if we set aside the convoluted language in Trump's initial announcement, it is worth noting that Trump was the one to whom the credit was attributed in the story of Soleimani's assassination. The intricate phrasing of his speech made that much clear. Beyond the rhetoric though, it was apparent from before the speech began that Soleimani's death was all about Trump, and had little to do with the American people. The news was not broken from inside the People's House. It was not even delivered in the nation's capital city. Rather, Trump chose to deliver the news from his own private resort in Florida, a state which voted overwhelmingly in his favor when he first ran for president in 2016 (Caputo \& Cheney, 2016). He stood behind a podium in an unremarkable room, before a drawn blue curtain, in a building and on a property that nets him and his family millions of dollars each year (Choi, 2017). Perhaps even more egregiously, choosing Mar-a-Lago as the setting for his speech necessitated the presence of both Trump's team and a team of Secret Service agents around him on the day of the speech. Each one of these individuals also had to be transported to Mar-a-Lago for the event—all of which cost U.S. taxpayers drastically more money than the speech might have otherwise cost had it been delivered inside the White House (and did not require transportation to and from Florida). 
Regardless of the cost or ethics associated with the leader of the free world conducting business from his own private resort, there is nothing presidential about the space. There may have been a few heads of state hosted at the resort, but the walls of Mar-a-Lago have seen only a sliver of the history built into every brick and fiber at the White House. The property is not renowned the world over for the world-altering and life-changing policies or programs that have flowed from behind its doors. Whatever room from which Trump delivered his speech presumably does not have an archived record of events and conversations that have transpired on-site. All this is a long-winded way of expressing one thing: the setting for Trump's potentially important speech was not presidential, and therefore did not lend Trump the air of presidentiality he was probably counting on as he embarked into the year in which he would run the fiercest election campaign of his life-and lose.

To some extent, we can analyze the choice of setting through Cicero's second canon, dispositio, or arrangement (Fan, n.d.). Trump's team presumably knew how important this speech was, yet arranged for (or allowed) Trump to deliver it from Mar-a-Lago. From the very beginning, then, the speech was doomed to noticeably lack presidentiality. In addition to the analysis of setting according to Cicero's canon, we can evaluate the choice from the perspective of ethos. Trump's credibility was weakened from the start, because his speech was not bolstered by the splendor and stateliness of the White House. Therefore, that setting decision cast a shadow over Trump's speech so that no matter what he said or in what order he said it, the president would not earn the same level of presidential acquiescence as his predecessors.

\section{Reliable (and Unreliable) Narrators}

In my analysis of Bush's (2003) speech, I discussed his reliability as a narrator at the time of his address and concluded that at least in the context of this speech, Bush was a reliable 
narrator. Audience members listening to or watching his speech on the day upon which it was delivered therefore probably received the content of the message and interpreted it as factual. Not only was the speech presumably factual, Bush's narrative in the speech seemed reasonable. To American audience members in particular, the events surrounding Bush's speech (namely the capture of Saddam Hussein) rang true with the narrative they understood about not only Hussein, but Iraq, the Middle East, and terrorism overall. The attacks of September 11, 2001 utterly shattered our global perspective. We were terribly frightened of the unknown and incredibly anxious that the exceptional America we had all grown up believing to be impervious was, in fact, vulnerable to attack. We were furious that any person or any entity had the nerve to attack us in the first place. And as a result, many Americans wanted revenge- and to avenge the loss of American lives and our sense of security.

With all that in mind, we spent the years following 9/11 attempting to work through our grief and fear, all the while trying desperately to pick up the pieces of our fractured worldview. Therefore, when President Bush approached the podium in the Cabinet Room and began to speak about bringing justice against a Middle Eastern terrorist (even though Hussein was not the one we really wanted to bring to justice), we accepted his narrative. It made sense to us, as we compared his story to the one we spent the days since 9/11 telling ourselves. After we filtered Bush's narrative through our own experiences and frames of reference, we concluded that Bush's presentation of the story carried with it a high degree of both narrative fidelity and probability. Thus, Bush's status as a reliable narrator was cemented even further beyond the truthfulness of his speech—we determined we could rely upon his word and the tale he wove around the information. 
President Obama should also be considered a reliable narrator in his 2011 speech announcing the successful assassination of Osama bin Laden. Admittedly, his reliability as a narrator wavered some after the press and public began to speculate about bin Laden's body. As mentioned, in the absence of a corpse on dry land, many questioned whether or not they could trust Obama's word that bin Laden was no longer a threat to Americans. However, those conspiracy theories were not yet in circulation at the time of this speech's delivery. Regardless of the stories the public would concoct after the speech's conclusion, Obama was a reliable narrator in the moment of the speech's delivery.

Unlike Bush, the American people were further removed from the brutal attacks of September 11, 2001. A sizable portion of Obama's much longer address was, therefore, dedicated to the remembering and retelling of the national narrative surrounding that fateful day. Obama forced us to recall the trauma we endured as we watched the horrors on our television screens or as we stood on the streets of New York City squinting through the soot-filled air. For those not yet alive in 2001 or were too young to remember, Obama relayed what it was like to experience a national tragedy that irrevocably altered all our worldviews. He brought us all back to the moment the world changed, and we were forced to reconsider our American identity. In so doing, Obama offered justification for his actions. Moreover, Obama walked the American people through a truncated retelling of events as they led to the inevitable assassination of bin Laden.

Given that this speech marked the first glance anyone had into the inner workings of the assassination plan, audience members were forced to take Obama's word at face value. We assumed he was telling the truth, because presidents generally have access to better information and in this moment, Obama had no reason to lie. After all, the death of bin Laden was cause for 
celebrations to countless Americans still grieving the unfathomable loss doled out to them just one decade prior.

By presenting a seemingly unobscured version of the reason why he and his administration chose to pursue bin Laden - as well as the recounting of the steps they took to reach the point at which he could announce to the world that America brought to justice one of the most wretched terrorists-Obama ensured that his words would reach individuals occupying both sides of the political ideological aisle. He ensured that regardless of how anyone felt about Obama, they could at least justify his actions. Because in taking out bin Laden, Obama acted not as a Democrat, but as an American also scarred by September 11, 2001-as an American justifiably hungry for retribution. In both regards, the story presented by Obama makes sense. It fits with the narrative we tell ourselves about terrorism and about $9 / 11$. We were the innocent victims, and the big bad guy needed to pay for what he did to us.

Osama bin Laden did not drive the planes that ultimately caused such devastation, but when we talked about $9 / 11$ in the ten years between the event and the eventual killing of bin Laden, we pointed our still-shaking fingers at him. bin Laden was the bad guy who caused all the death and destruction. He needed to pay. Therefore, like Bush's speech in 2003, Obama's (2011) address announcing the long sought-after passage of bin Laden maintained high degrees of both narrative fidelity and narrative probability.

Once again, Trump is the exception to the trend followed by the previous two speeches in this niche category of speeches delivered following the elimination of a Middle Eastern terrorist threat. Prior to the moment Trump stepped up to the podium in the unknown room in Mar-aLago, his credibility was shaky at best, and had been shaky since long before he announced his 
candidacy for presidency. Generally speaking, the veracity of Trump's statements has been under review as long as Trump has occupied the public spotlight.

For example, years before his name appeared on a ballot in a federal election, Trump was known for stoking the flames of the "birtherism" conspiracy way back in 2011, just shortly before Obama made public the American achievement of killing Osama bin Laden (Falcone, 2011). The basis of the story was, of course, that Barack Obama was constitutionally ineligible to serve as president because he was not a naturally born citizen of the United States of America. Eventually proved false, this story serves as one example among thousands of times Trump either lied or perpetuated a mistruth. According to The Washington Post, in his four-year stint as president, Trump made an alarming 30,573 (public) false or misleading claims (Kessler et al., 2021). This unprecedented record for untruths offered the American people no reason to blindly trust his claims.

When Trump stepped up to the podium — his credibility as president already weakened by the less than prestigious or presidential setting - to announce that Soleimani was dead, under his leadership and at the hands of military operatives, many Americans were suspicious. It did not help matters that few Americans had any idea who Soleimani was, or how he was relevant to our national security. Soleimani did not have ties to $9 / 11$, our most impactful memory of terrorism, so we could not situate his death in relation to that narrative. Unlike Hussein or bin Laden, Soleimani had conducted relatively few attacks against Americans. Unlike bin Laden specifically, none of those attacks were on American soil. If Americans felt any enmity toward Soleimani, it was because Trump (2020) associated Soleimani with terrorism. By alleging that Soleimani was "plotting imminent and sinister attacks on American diplomats and military personnel” (para. 4) or even by simply calling Soleimani a "terrorist" (para. 5), the president 
redefined American reality (Zarefsky, 2004). He took an ambiguous and unknown entity (Qasem Soleimani) and connected him to a concept better understood by Americans (terrorism).

In the space of just two short paragraphs at the beginning of Trump's speech, many Americans - particularly those who supported him and therefore were more likely to trust and approve of his messaging — read between the lines to connect Soleimani to terrorism to evil. That enthymeme prompted another response, because Americans know how to respond to evil people. Our history bolsters itself upon American heroism and exceptionalism. As such, when presented with an evil foe, there is only one possible course of action: the evil foe must be eliminated. The evil foe cannot be allowed to attack anyone or anything else ever again.

If this is how audience members perceived the president's speech, then Trump probably seemed reasonable and reliable. If they supported the president, even after three years of welldocumented lies, then the individuals most likely to perceive the speech in this way were also the ones most likely to accept at face value the allegation that Soleimani was planning a villainous attack against the United States. I do not agree with this perspective. However, if I set my own beliefs and partisan positions aside, I can at least recognize an indisputable sense of internal coherence and fidelity in Trump's narrative, according to the beliefs of his supporters.

For many others though (like myself), Trump's narrative did not hold consistent according to our worldviews or experiences. I, for one, remember questioning who Qasem Soleimani was. I asked, how could this person I've never even heard of wield such influence over our country? The timing and the object of assassination did not quite make sense. No evidence of an allegedly imminent attack was presented, and so, felt a bit like a flimsy lie. It felt like the kind of lie a young child might tell by omitting part of the truth. Had Trump offered any more information about the purportedly planned attacks—-such as how American intelligence officials 
were made aware of the plans or where Soleimani intended to strike or how close Soleimani and his men were to acting upon their villainous plans_-perhaps Trump's justifications for assassination may have seemed more reasonable.

Though it does not in any way color my analysis of Trump as an unreliable narrator, my suspicions here were confirmed days after Trump's speech. In the ballroom of Trump's Mar-aLago resort, Trump was recorded telling major campaign contributors that Soleimani "was saying bad things about our country" instead of explaining in any greater detail the purported threat (Liptak, 2020, para. 3). If this is true, Trump may have assassinated a highly-regarded Iranian general for spreading unfavorable information about Trump's "great" nation, taking his campaign slogan "make America great again" to an entirely new level. It is especially obvious in the recording that Trump takes American exceptionalism so seriously that anyone who dares to speak against American greatness ought to beware of American retribution. Because while bin Laden's crime was the killing of thousands of Americans, Soleimani's crime was speaking unfavorably about America, and both their sentences were death. It certainly calls into consideration the questions, was the president (the judge, jury, and executioner in each circumstance) reliable? Can we trust his judgment? Was he really justified in jeopardizing American security to assassinate a terrorist?

Even without the later revelation that Soleimani may not have been planning an attack against Americans, Trump went into the address with a reputation as someone familiar with falsehoods. He began the speech in an unpresidential setting. And he did not offer enough justification — beyond the accusation that a terrorist attack lie imminently on the horizon — for his decision to assassinate Soleimani. Combined, these aspects of Trump's speech led me to conclude that the president had low degrees of narrative fidelity and probability. His credibility 
was already weakened, and even while giving the speech, he came across as an unreliable narrator. More importantly, Trump's story had in it too many holes to be considered watertight. And ultimately, it did not make sense. The only aspect in which I can concede my previous statement — that Trump's story did not make sense — is in regard to timing. Trump's story makes a great deal of sense if we evaluate it from the perspective that he and his campaign team were preparing to launch full-speed (with renewed enthusiasm) into re-election campaigning. Had this story been well received, it may have laid out a red carpet for a strong start in those campaign efforts. That said, how Trump could possibly expect to compete with his grandiose escalator descent into his first presidential campaign announcement is downright unfathomable. Regardless, for the most part, audiences could not filter Trump's story about Soleimani through past perceptions of —or personal experiences with—terrorism, because was inherently different from their understandings of terrorism.

\section{The Flag Around Which We (Might Not) Rally}

Before Bush announced to the world that heroic American soldiers successfully nabbed Saddam Hussein, polls were not boding well for him or for his presidency. As of the Saturday evening before Bush's speech on Sunday, his general job approval rating was 52\%. Another $40 \%$ of Americans polled that night stated they disapproved of the president's job performance. And an overwhelming $47 \%$ of respondents disapproved of how the president handled foreign affairs (Nagourney \& Elder, 2003).

After his speech in the Cabinet Room, Bush's overal approval rating jumped to $58 \%$ on Sunday - marking a six point increase within a twenty-four hour window. In the same poll, only $33 \%$ of Americans dissaproved of his performance as president. Perhaps the most striking difference between the Saturday and Sunday evening polls was in the final number: Bush 
enjoyed a nine point difference in the percent of respondents who disapproved of his handling of foreign affairs (Nagourney \& Elder, 2003). These overnight changes demonstrate that the boost in Bush's poll numbers arrived on the coattails of his announcement. Nagourney and Elder (2003) even observed that 'the capture of Saddam Hussein has lifted Americans' view of the state of the nation" (para. 1).

In the year 2021, we have become accustomed to questioning (and occasionally disregarding) poll numbers. They have been wrong before. If nothing else, polls might just be a distraction from the reality in a campaign season that regardless of what the poll says, there is always more work to be done. But in 2003, the New York Times/CBS News poll to which Nagourney and Elder (2003) refer painted a clear picture. As a direct result of Hussein's capture and Bush's subsequent announcement broadcasting the news of Hussein's capture, more Americans felt positively about their nation and about their president. Their perception of American strength and exceptionalism was restored for perhaps the first time since September 11, 2001 when that sense of exceptionalism collapsed alongside the Twin Towers and the western side of the Pentagon. In more ways than one, Americans gathered that feeling of strength and used it to rally around the flag, that still-standing symbol for freedom and exceptionalism and exemplarism and interventionism and the United States of America. In a stunning example of synecdoche at work in the real world, Americans also rallied around their president - a symbol in his own right of the nation over which he presides.

Americans rallied around Bush not only as a symbol of their patriotism, but also as a symbol of their security. According to a Wall Street Journal/NBC News poll, $60 \%$ of Americans (up from 50\% just a few months before Bush's announcement) believed the nation to be safer since Bush opted to invade Iraq and capture the Iraqi president, Saddam Hussein (Greene, 2003). 
Bush's decision to act against Hussein made Americans feel more secure. Like a parent protecting a child from a schoolyard bully, Bush intervened to make his constituents feel safer. When paired with the overall improvement in the polls immediately following Bush's announcement, the admiration Americans felt toward the president's paternal display served him well. In the same poll cited by Greene (2003), Bush won when pitted against Democratic challengers across the board. As such, his actions to keep Americans safe in the War on Terror would not soon be forgotten. The memory of Bush (2003) behind a podium, declaring "United States military forces captured Saddam Hussein alive" (para. 1) lingered in the backs of our minds. It accompanied voters into their polling places the following year. It might have even helped Bush earn a second term in the White House.

Bush was not the only president to accrue sharp upticks in his poll numbers following his announcement of the elimination of a terrorist threat. In fact, the Obama administration experienced a very similar spike to the one enjoyed by the Bush administration eight years earlier. After the conclusion of his speech, Obama's job approval ratings increased six percentage points overall, settling on a $52 \%$ job approval rating that the administration maintained for several days. Especially interesting is the spike in Obama's job approval rating among Republican and independent voters. Independents' perception of the president's performance improved by nine points. Among Republicans surveyed, 21\% reported they approved of Obama's performance in the White House in the two days following his announcement about bin Laden's death—up from a mere $9 \%$ the day before the successful raid (Jones, 2011). These polling increases are consistent with abrupt leaps in favorability ratings in other administrations. Data analysts anticipate jumps after matters of national or international 
consequence (such as the capture or assassination of a wanted terrorist). We attribute these increases to the "rally 'round the flag" effect.

In the aftermath of $9 / 11$, we felt the full weight of heightened emotions around the country. We felt our grief and fear and bloodlust like a suffocating weighted blanket filled with three times the recommended amount of plastic beads. It hurt to breathe, to move, to think about the anguish and loss of losing loved ones and neighbors, and the anger we felt toward the villains who robbed us so viciously of our joy and proud American identity. President Obama resurrected those feelings by reminding Americans about the tragedy through which we all lived, that we still remember vividly and with a sharp ache in our hearts. Combined, our fear, grief, and bloodlust enabled us to unite (or rally) around our president (and synecdochally, our nation) in a shared demonstration of patriotism. We felt proud to be the exceptional ones once more, to be esteemed as the only country capable of not only locating bin Laden, but also terminating his life in a swift act of justice. We felt secure because the real-life threat of our worst nightmares was eliminated. And we felt comforted by the knowledge that our president acted paternally to ensure our greatest enemy was conquered.

It is impossible to determine for sure that these announcement speeches played any significant role in the re-election campaigns of Presidents Bush and Obama. However, based on the criteria analyzed in this essay, only two of the three presidents analyzed were re-elected to serve a second presidential term. The speeches of both those presidents (Bush and Obama) shared many similar characteristics. Both speakers chose to speak from inside the White House, as if to emphasize their position as president and occupant of the People's House. Both speakers presented the news in a straightforward, presidential manner. Both speakers employed themes of justice and unity in their addresses. Both speakers told a story of collective American resilience 
and predicted a strong future for the country they loved, promising that even though there would be inevitably more hardships looming across the horizon that there was still cause for celebration as they spoke. From my perspective, both Bush and Obama were unquestionably reliable narrators. And both experienced significant boosts in their poll numbers after their announcements. Most importantly, both speakers were re-elected to serve a second consecutive term as President of the United States.

Trump was not re-elected. On November 7, 2020, news finally broke that after much anticipation, the 2020 presidential election had been called in favor of President Joe Biden (Lemire et al., 2020). So what changed? If Trump followed the trend laid out in the administrations of his predecessors, eliminated a terrorist threat, and announced that action with a grandiose speech — just like Obama and Bush before him — why was his victory not assured a year after he gave his speech?

\section{Implications}

If we look at the outcomes of the elections as results of only these three speeches' reception by the American electorate, there is a clear answer. Trump's speech was less presidential. It was delivered outside the American capital and outside the White House. His speech felt disingenuous to half of the nation. As such, only his supporters rallied 'round the flag (presidency) that day. In fact, Trump's favorability rating did not increase or decrease between mid-December to early January when he announced the American assassination of "the numberone terrorist anywhere in the world" (Trump, 2020, para. 3). Rather, his overall favorability rating remained stable at $41 \%$ (Kahn, 2020). Along the same lines, "the number of adults who 'strongly disapprove' of Trump's actions in Iran” increased 10\% from the poll conducted just weeks before Soleimani's death (Kahn, 2020, para. 3). That statistic followed party-lines, as 
Trump's approval rating regarding his dealings with Iran held steady among Republican respondents, while Democrat and independent voters expressed their staunch disapproval.

Whether he was hoping to capitalize on a similar bump in his poll numbers as the ones experienced by Bush and Obama in their own similar situations at similar points in the reelection process is irrelevant. Such an increase could have helped a great deal in his effort to secure another term in the White House, but it did not help him. Rather, quite the opposite is true. By assassinating Qasem Soleimani and then announcing it in a speech at his private resort, Trump actually hurt his perception in Americans' eyes. His handling of the situation—whatever that situation may have been, given the lack of clarity in his speech—only really served to sow greater distrust into an American electorate already uneasy with the prospect of an extended Trump presidency.

Unfortunately, we cannot draw a straight line between these speeches and the outcome of their respective speakers' re-election campaigns. To do so would not only be a prime example of a post hoc ergo propter hoc fallacy (implying that since Trump's loss occurred after the speech, the speech caused the loss), it would also only illuminate one pixel in a massive and highly detailed photograph of the complicated American electoral process. Moreover, to imply such a connection might actually be dangerous. I do not, in writing this essay, intend to imply that a well-crafted speech and a strategically-timed assassination of a Middle Eastern "terrorist" will earn an incumbent a stronger chance at victory. Rather, when I set out to write this essay, I only meant to illuminate the existence of the pattern.

The three speeches analyzed in this essay were delivered under eerily similar conditions. Most notably, each address was delivered approximately one year before a re-election campaign. Each speech builds upon the one before it, like episodes in a running series with one overarching 
storyline: the exceptional paternal American heroes triumph over big bad terrorists again. As such, it is challenging to keep from speculating that with each reiteration of the capture/assassination $\rightarrow$ speech $\rightarrow$ increased favorability $\rightarrow$ election cycle, the perception that this is one brick in the paved path to presidential victory strengthens.

Beyond the analysis I conducted in this criticism, there is still plenty of room for analysis in this arena. These speeches should be analyzed by other scholars, because they have massive implications for American identity and American standing on a global playing field. They should be analyzed through different lenses as well. For example, while building from my analysis, future research could explore the advent of a new genre of presidential speeches to encapsulate these three presidential addresses.

As Brummet (2019), writes, "genre is a natural extension of narrative... [like] a recurring type of text within a context" (p. 57). The context of the three speeches for which I propose a new genre is the elimination of a Middle Eastern (or otherwise Othered) terrorist threat by an American president/presidential administration. And unless another speech is delivered soon by newly elected President Biden (or Biden does not seek another term as president), the text and context of these speeches occur approximately every eight years - in the context of an ongoing re-election campaign. As such, the situation requiring the speech is a recurring one, and each recurring situation generally calls for the same response from both the president and audience members. That is the "key to a genre: audience expectations. People come to a graduation expecting to hear certain kinds of texts. They may hear them, and they may not, but what they hear is judged in comparison to the generic expectations" (Brummet, 2019, p. 57). Just as audience members prepare to hear joyful and reflective speeches at recurring graduation situations, Americans have been exposed to enough of the circumstances explored in this thesis 
that we have come to expect certain themes, tones, settings, and types of responses from our Commander-in-Chief. In this manner, genre can be considered as a sort of recurring narrative. When I began the work of combing through these speeches and the limited scholarship in this area, I did not yet know if the addresses delivered by Presidents Bush, Obama and Trump on the taking out of a Middle Eastern terrorist threat could be evaluated together under the umbrella of one genre. Through my analysis, however, I believe I uncovered a possible new genre by identifying the shared commonalities between the three speeches in this genre. It is my hope that this thesis project might serve as a framework for future analysts, who can use the conclusions afforded to me by my narrative and close textual analysis to guide their own research. As such, future analyses should be conducted to review what additional elements of this recurring narrative might exist outside the traditional elements of narratives I explored in this thesis project. This broadened analysis will hopefully shed more light on how these speeches fit together as episodes in the overarching story.

I fear that if we do not begin noticing such patterns, the cycle will continue, enticing future presidents to pursue terrorists in the final years of their administrations for political gain. Future research (like the analysis conducted in this essay) might enlighten Americans to the existence of this trend, and could prevent future presidents from intervening in the Middle East (or elsewhere) for political motives. Moreover, nearly the same message was presented in three rather different ways — and had different effects on their associated presidential administrations' attempts to secure re-election the following year. Therefore, it is my hope that this analysis might inform future speechwriters about the consequences and reception of the construction of their presidential speeches on matters of national security and leadership. 
Regardless, by voting to re-elect President Bush and President Obama after their speeches, we granted our leaders our post facto approval. We retroactively consented to the actions and handling of the taking out of these terrorists. By voting to re-elect President Bush and Obama (at least in the limited context of these speeches), we affirmed their presentation of "truth." From within the confines of the polling booth, we communicated our confidence in the president's ability to lead. Bush and Obama were evidently fit enough to lead us through the respective capture of Hussein and assassination of bin Laden, so they must be fit enough to continue serving their great and exceptional nation. They were both capable of viewing the bigger picture, of understanding the ramifications of their actions or inactions. And perhaps most importantly, their careful speeches spoke volumes about their high regard for their constituents. Their addresses demonstrated their ethos - their ability to care not just for themselves or for their country's citizens, but also for the other peoples who would be forced to live with the consequences of their actions against terrorists in the Middle East.

Perhaps when we placed our ballots in mailboxes and stood six feet apart at polling places this past November, we voted a bit differently than in past elections because of the lessons we learned from these three speeches. Because, when Bush and Obama spoke, their rhetoric was presidential, paternal, and reassuring. Conversely, Trump's speech was riddled with what Hyvönen (2018) would call "careless speech," for his disregard of "other perspectives, [and his] reluctance to accept that speech has repercussions and words matter" (p. 33). Trump's carelessness and unpresidential demeanor in a consequential moment in American history communicated his incapability of looking ahead, of telling the truth, and regarding any person or persons beyond himself and his most loyal supporters. It surely helped to ultimately convince the majority that Trump was not fit for re-election. 
In that regard, these speeches serve not as hard lines connecting campaigning presidents to their electoral outcomes, but rather as microcosms of their presidencies. In other words, these speeches offer insight into why voters feel positively or negatively toward an incumbent president. They reveal how trustworthy and presidential a sitting president is in the eyes of his constituency.

So if there is any great takeaway from my analysis, it is this: Words $d o$ matter.

The words chosen and the way presidential speeches are composed have great impacts on their presidents, the American people, and the way we understand our place and role in the world. The manner (as well as the setting) in which such addresses are delivered by the president connect directly to the reception of the message contained within. And they may have a lasting impact on the future of the nation by helping voters determine who should serve as their next Commander-in-Chief. 


\section{REFERENCES}

9/11 Memorial \& Museum. (2021). Names on the 9/11 Memorial. 9/11 Memorial \& Museum. https://www.911memorial.org/visit/memorial/names-911-memorial

Abdelaal, N. M., Alisood, A. M., \& Sase, A. S. (2015). Investigating Obama's ideology in his speech on Islamic State of Iraq and Levant (ISIL). Journal of Applied Linguistics and Language Research, 2(7), 228-246.

Alaimo, K. (2017). Measuring the boundaries of America's permanent campaign. Journal of Public Affairs, 17(4) 1-6. https://doi.org/10.1002/pa.1682.

Althaus, S. L., \& Largio, D. M. (2004). When Osama became Saddam: Origins and consequences of the change in America's public enemy \#1. Political Science \& Politics, 37(4), 795-799. doi:https://doi.org/10.1017/S1049096504045172

Aristotle. (1926). Aristotle: The art of rhetoric (Vol. Volume XXII). (J. H. Freese, Trans.). Harvard University Press.

Axios, A. (2014, September 15). Opening the people's house. Retrieved from The White House: President Barack Obama: https://obamawhitehouse.archives.gov/blog/2014/09/15/opening-peoples-house

Baker, W. D., \& O'Neal, J. R. (2001). Patriotism or opinion leadership? The nature and origins of the 'rally 'round the flag' effect. Journal of Conflict Resolution, 45, 661-687. https://doi.org/10.1177/0022002701045005006.

Barnes, J. E. (2019, December 27). American contractor killed in rocket attack in Iraq. The New York Times. https://www.nytimes.com/2019/12/27/us/politics/american-rocket-attackiraq.html 
Barnes, J. E. (2019, December 29). U.S. launches airstrikes on Iranian-backed forces in Iraq and Syria. The New York Times: https://www.nytimes.com/2019/12/29/world/middleeast/usairstrikes-iran-iraq-syria.html

Bassiouni, M. C., \& Wahid Hanna, M. (2007). Ceding the high ground: The Iraqi High Criminal Court statute and the trial of Saddam Hussein. Case Western Reserve Journal of International Law, 39, 20-97. https://scholarlycommons.law.case.edu/jil/vol39/iss1/3.

Bitzer, L. F. (1968). The rhetorical situation. Philosophy and Rhetoric, 1. https://www.jstor.org/stable/40236733.

Blackburn, S. (2008). Paternalism. In The Oxford Dictionary of Philosophy (p. 270). Oxford University Press.

Blumenthal, S. (1982). The permanent campaign. Simon \& Schuster.

Bostdorff, D. M. (2003). George W. Bush's post-September 11 rhetoric of covenant renewal: Upholding the faith of the greatest generation. Quarterly Journal of Speech, 89(4), 293319. https://doi.org/10.1080/0033563032000160963.

Browne, S. H. (2009). Close textual analysis: Approaches and applications. In J. A. Kuypers (Ed.), Rhetorical criticism: Perspectives in action (pp. 63-76). Lexington Books.

Brummett, B. (2019). Techniques of Close Reading ( $2^{\text {nd }}$ ed.). SAGE Publications.

Brydon, S. (2004). Dueling prophets: The return of prophetic dualism to foreign policy rhetoric after September 11, 2001. Paper presented at the annual conention of the International Communication Association. New Orleans, LA: International Communication Association.

Bureau of Diplomatic Security. (2019, February 21). 1993 World Trade Center bombing. U.S. Department of State. https://www.state.gov/1993-world-trade-center-bombing/ 
Burke, K. (1969). A rhetoric of motives. University of California Press.

Bush, G. W. (2001, September 21). Transcript of President Bush's address. CNN. https://edition.cnn.com/2001/US/09/20/gen.bush.transcript/

Bush, G. W. (2002, June 1). President Bush delivers graduation speech at West Point. The White House Archives: President George W. Bush. https://georgewbushwhitehouse.archives.gov/news/releases/2002/06/20020601-3.html

Bush, G. W. (2003, December 14). President Bush addresses nation on the capture of Saddam Hussein: Remarks by the President on the capture of Saddam Hussein. The White House Archives. https://georgewbush-whitehouse.archives.gov/news/releases/2003/ 12/20031214-3.html

Bush, G. W. (2003, February 27). Full Text: George Bush's speech to the American Enterprise Institute. The Guardian. https://www.theguardian.com/world/2003/feb/27/usa.iraq2

The capture of Hussein: 'We got him,' and then a call by American and Iraqi officials for reconciliation. (2003, December 15). The New York Times. https://www.nytimes.com/2003/12/15/world/capture-hussein-we-got-him-then-callamerican-iraqi-officials-for-reconciliation.html

Caputo, M., \& Cheney, K. (2016, November 8). How Trump won Florida: Trump's Florida win was a microcosm of what unfolded nationwide. Politico. https://www.politico.com/story/2016/11/florida-results-not-in-2016-231004

Cherelus, G. (2017, January 25). Trump's Mar-a-Lago resort hikes membership fees to $\$ 200,000$. Reuters. https://www.reuters.com/article/us-usa-trump-resort/trumps-mar-a-lago-resorthikes-membership-fees-to-200000-idUSKBN1592NW 
Childers, J. (2007, November). Citizens at the kid's table: George W. Bush's paternal rhetoric of exclusion. Paper presented at the annual conference of that National Communication Association, Chicago, IL.

Choi, D. (2017, June 16). Mar-a-Lago, the Florida resort where Trump has spent 25 days since taking office, sees huge boost in revenue. Insider. https://www.businessinsider.com/howmuch-does-trump-make-on-maralago-financial-disclosure-2017-2017-6

CIA. (2007, April 23). Regime strategic intent. Central Intelligence Agency (CIA).

https://web.archive.org/web/20110524161001/https://www.cia.gov/library/reports/genera 1-reports-1/iraq_wmd_2004/chap1.html

Cicero: Volumes III-IV, De Oratore, Books I-III. (1942). (E. W. Sutton, \& H. Rackham, Trans.) Harvard University Press.

Cook, C. (2002). "The Contemporary Presidency": The permanence of the "Permanent Campaign": George W. Bush's public presidency. Presidential Studies Quarterly, 32(4), 753-764. https://doi.org/10.1111/j.0360-4918.2002.00246.x.

Congressional Budget Office. (2008, April 8). The cost of war: A comment on Stiglitz-Bilmes. Congressional Budget Office (CBO). https://www.cbo.gov/publication/24762

Costello, M. (2018, October 5). A brief history of the presidential seal. White House Historical Association. https://www.whitehousehistory.org/a-brief-history-of-the-presidential-seal Council on Foreign Relations. (2019, December). U.S. adults' knowledge about the world. Council on Foreign Relations. https://www.cfr.org/report/us-adults-knowledge-aboutworld 
Crawford, J. (2004, September 14). No Child Left Behind: Misguided approach to school accountability for English language learners. National Association for Bilingual Education.

Dao, J., \& Sussman, D. (2011, May 4). For Obama, big rise in poll numbers after bin Laden raid. The New York Times. https://www.nytimes.com/2011/05/05/us/politics/05poll.html

Department of Homeland Security. (2021, January 27). National Terrorism Advisory System (NTAS). Retrieved from Homeland Security: https://www.dhs.gov/national-terrorismadvisory-system\#: :text=In\%202011\%2C\%20the\%20Department $\%$ 20of,detailed\%20information\%20to\%20the\%20American

Disha, I., Cavendish, J. C., \& King, R. D. (2011). Historical events and spaces of hate: Hate crimes against Arabs and Muslims in Post 9/11 America. Social Problems, 58(1), 21-46. https://doi.org/10.1525/sp.2011.58.1.21.

Edwards, G. C. (2003). On deaf ears: The limits of the bully pulpit. Yale University Press.

Edwards, J. A. (2018). Make America great again: Donald Trump and redefining the U.S. role in the world. Communication Quarterly, 66(2), 176-195. https://doi.org/10.1080/01463373.2018.1438485.

Eiholm Kjær, S. A. (2020, Spring). Securitization and the power of language: A discourse analysis of the legitimization of the assassination of Major General Soleimani. Malmö University. Malmö, Sweden: Department of Global Political Studies: Peace and Conflict Studies.

Falcone, M. (2011, March 28). Donald Trump steps up calls for Obama to release birth certificate. $A B C$ News. https://abcnews.go.com/Politics/donald-trump-embracesbirther/story?id=13240431 
Fan, J. (n.d.). Interpreters as orators: Cicero's classical canons of rhetoric and their relevance to interpreter training. https://www.academia.edu/5435999/Interpreters_as_orators_Cicero_s_classical_canons_ of_rhetoric_and_their_relevance_to_interpreter_training

Farrell, K. M., \& Young, M. J. (2003). Not in our names: The administration's private construction of the War Against Iraq. Conference Proceedings - National Communication Association/American Forensic Association, (pp. 719-725).

Federal Election Commission. (December 2017). Federal elections 2016: Election results for the U.S. President, the U.S. Senate, and the U.S. House of Representatives.Federal Election Commission. Retrieved from https://www.fec.gov/resources/cmscontent/documents/federalelections2016.pdf

Fisher, W. R. (1984). Narration as a human communication paradigm: the case of public moral argument. Communication Monographs, 51, 1-22. https://doi.org/10.1080/03637758409390180.

Fowler, R. (2019). Art of the arms deal: Reagan, AWACS, and the rhetorical presidency. Quarterly Journal of Speech, 105(3), 273-296. https://doi.org/10.1080/00335630.2019.1628999.

Gershkoff, A., \& Kushner, S. (2005). Shaping public opinion: The 9/11-Iraq connection in the Bush administration's rhetoric. American Political Science Association, 3(3), 525-537. https://doi.org/10.1017/s1537592705050334.

Gramsci, A. (1971). Selections from the prison notebooks of Antonio Gramsci: 1891-1937. International Publishers. 
Greene, D. L. (2003, December 17). Capture of Hussein gives Bush a boost in polls. The Baltimore Sun. https:/www.baltimoresun.com/news/bal-te.bush17dec17-story.html

Gries, L. E. (2015). Still life with rhetoric: A new materialist approach for visual rhetorics. Utah State University Press.

Gul, A. (2020, January 11). Taliban-planted bomb kills 2 US soldiers in Afghanistan. VOA. https://www.voanews.com/usa/taliban-planted-bomb-kills-2-us-soldiers-afghanistan

Hariman, R. (2003). Speaking of evil. Rhetoric \& Public Affairs, 6(3), 511-517. doi:10.1353/rap.2003.0064.

Harle, V. (2000). The enemy with a thousand faces: The tradition of the other in Western political thought and history. Praeger Publisher.

Hiland, A. (2020). Presidential power, rhetoric, and the terror wars: The sovereign presidency. Lexington Books.

Hill, F. I. (2009). The "traditional" perspective. In J. A. Kuypers (Ed.), Rhetorical criticism: Perspectives in action (pp. 39-61). Lexington Books.

Hogan, J. M. (1995). Demonization, public opinion, and the Gulf War. Conference Proceedings National Communication Association/American Forensic Association, (pp. 498-500). Holland, S. (2007, August 1). Tough talk on Pakistan from Obama. Reuters. https://www.reuters.com/article/us-usa-politics-obama/tough-talk-on-pakistan-fromobama-idUSN0132206420070801

Holy Bible, New International Version. (1984). Zondervan Publishing House.

Hongju Koh, H. (2003). On American exceptionalism. Stanford Law Review, 55(5), 1479-1527.

Howell, W. G. (2003). Power without persuasion: The politics of direct presidential action. Princeton University Press. 
Hyvönen, A. (2018). Careless speech: Conceptualizing Post-Truth politics. New Perspectives: Interdisciplinary Journal of Central \& East European Politics \& International Relations, 26(3), 31-55. doi:https://doi.org/10.1177/2336825x1802600303

Ingraham, C. (2020, September 2). Covid-19 has killed more police officers this year than all other causes combined, data shows. The Washington Post.washingtonpost.com/business/2020/09/02/coronavirus-deaths-police-officers-2020/

John F. Kennedy Presidential Library and Museum. (2020). State funeral of President Kennedy: Lying in repose in the East Room of the White House. John F. Kennedy Presidential Library and Museum. https://www.jfklibrary.org/assetviewer/archives/JFKWHP/1963/Month\%2011/Day\%2023/JFKWHP-1963-11-23-B

Jones, J. M. (2011, May 5). Obama approval rallies six points to 52\% after bin Laden death. Gallup News. https://news.gallup.com/pol1/147437/obama-approval-rallies-six-pointsbin-laden-death.aspx

Kahn, C. (2020, January 7). Americans increasingly critical of Trump's record on Iran, most expect war: Reuters/Ipsos poll. Reuters.https://www.reuters.com/article/us-usa-trumpiran-pol1/americans-increasingly-critical-of-trumps-record-on-iran-most-expect-warreuters-ipsos-poll-idUSKBN1Z62KF

Keith, W. M., \& Lundberg, C. O. (2008). The essential guide to rhetoric. Bedford/St. Martin's.

Kessler, G., Rizzo, S., \& Kelly, M. (2020, July 13). President Trump has made more than 20,000 false or misleading claims. The Washington Post. Retrieved from https://www.washingtonpost.com/politics/2020/07/13/president-trump-has-made-morethan-20000-false-or-misleading-claims/ 
Kessler, G., Rizzo, S., \& Kelly, M. (2021, January 24). Trump's false or misleading claims total 30,573 over 4 years. The Washington Post. https://www.washingtonpost.com/politics/2021/01/24/trumps-false-or-misleading-claimstotal-30573-over-four-years/

Killian, J. (2008, November). Benevolent hegemony, American exceptionalism, and elusive enemies: Retheorizing foreign policy rhetoric in a post September 11th world. Paper presented at the annaul meeting of the National Communication Association. San Diego, CA.

Kuypers, J. A., \& King, A. (2016). What is rhetoric? In J. A. Kuypers (Ed.), Rhetorical criticism: Perspectives in action (2nd ed., pp. 7-20). Rowman \& Littlefield.

Lambert, A. J., Schott, J. P., \& Scherer, L. (2011). Threat, politics, and attitudes: Toward a greater understanding of Rally-'Round-the-Flag effects. Current Directions in Psychological Science, 20(6), 343-348. https://doi.org/10.1177/0963721411422060

Lee, J. (2009, May 12). Poetry, music, and spoken word. Obama White House Archives. https://obamawhitehouse.archives.gov/blog/2009/05/12/poetry-music-and-spoken-word

Lee, M. J. (2017). Us, them, and the war on terror: Reassessing George W. Bush's rhetorical legacy. Communication and Critical/Cultural Studies, 14(1), 3-30. https://doi.org/10.1080/14791420.2016.1257817.

Lemire, J., Miller, Z., \& Weissert, W. (2020, November 7). Biden defeats Trump for White House, says 'time to heal'. Associated Press:.https://apnews.com/article/joe-biden-winswhite-house-ap-fd58df73aa677acb74fce2a69adb71f9

Liptak, K. (2020, January 18). Trump recounts minute-by-minute details of Soleimani strike to donors at Mar-a-Lago. CNN Politics. 
Lockett, S., John, D., Domke, D., Coe, K., \& Graham, E. S. (2007). Going public, crisis after crisis: The Bush administration and the press from September 11 to Saddam. Rhetoric and Public Affairs, 10(2), 195-220. https://doi.org/10.1353/rap.2007.0039.

Madsen, D. L. (1998). American exceptionalism. University Press of Mississippi.

Maggio, J. (2007). The presidential rhetoric of terror: The (re)creation of reality immediately after 9/11. Politics \& Policy, 35(4), 810-835. https://doi.org/10.1111/j.17471346.2007.00085.x.

Makstenieks, S. (2007, November). The end of innocents: Exceptionalism and the Bush Administration's "War on Terrorism". Paper presented at the annual meeting of the National Communication Association, Chicago, IL.

The Mar-a-Lago Club. (2021). Trump Card Privileges Program. Retrieved from The Mar-aLago Club: https://www.maralagoclub.com/default.aspx?p=DynamicModule\&ssid=100001\&vnf=1\& navRefresh=1\&PageId=1

Mandarani, V., \& Fakhruddin, M. Z. (2020, April). Grammatical and lexical cohesion analysis of Trump's speech upon Soleimani assassination. Journal B.A.S.I.S, 7(1), 131-139. https://doi.org/10.33884/basisupb.v7i1.1753.

Martin, J. (2014). Politics and Rhetoric: A Critical Introduction. Routledge.

McFarlane, M. D. (2016). Visualizing the rhetorical presidency: Barack Obama in the Situation Room. Visual Communication Quarterly, 23(1), 3-13. https://doi.org/10.1080/15551393.2015.1105105. 
Medhurst, M. J. (2008). Afterword: Questioning the rhetorical presidency construct. In M. J. Medhurst (Ed.), Before the rhetorical presidency (pp. 333-334). Texas A\&M University Press.

Milford, M. (2016). National identity, crisis, and the inaugural genre: George W. Bush and 9/11. Southern Communication Journal, 81(1), 18-31. https://doi.org/10.1080/1041794x.2015.1064989.

Miroff, B. (2003). The presidential spectacle. In M. Nelson (Ed.), The presidency and the political system (pp. 255-282). CQ Press.

Murphy, J. M. (2003). "Our mission and our moment": George W. Bush and September 11th. Rhetoric \& Public Affairs, 6(4), 607-632. https://doi.org/10.1353/rap.2004.0013.

Nagourney, A., \& Elder, J. (2003, December 17). The 2004 campaign: The poll; Bush's approval ratings climb in days after Hussein's capture. The New York Times. https://www.nytimes.com/2003/12/17/us/2004-campaign-poll-bush-s-approval-ratingsclimb-days-after-hussein-s-capture.html

Naji, K. (2020, January 7). Soleimani: Why huge crowds turned out for Iran commander's funeral. BBC News. https://www.bbc.com/news/world-middle-east-51021854

Neustadt, R. E. (1990). Presidential power and the modern presidents: The politics of leadership from Roosevelt to Reagan. The Free Press.

The New York Herald. (1874, May 21). White House nuptials: A brilliant assemblage in the East Room. The New York Herald.

Obama, B. (2011, May 2). Remarks by the president on Osama bin Laden. The White House: President Barack Obama. https://obamawhitehouse.archives.gov/the-pressoffice/2011/05/02/remarks-president-osama-bin-laden 
Obama, B. (2020). A promised land. Crown Publishing.

The Obama White House. (2009, November 2). Lin-Manuel Miranda Performs at the White House Poetry Jam: (8 of 8) [Video]. YouTube. https://www.youtube.com/watch/WNFf7nMIGnE

Oddo, J. (2014). Variation and continuity in intertextual rhetoric: From the "War on Terror" to the "Struggle Against Violent Extremism". Journal of Language and Politics, 13(3), 512537. https://doi.org/10.1075/jlp.13.3.07odd.

Office of the High Commissioner. (1977, June 8). Protocol additional to the Geneva Conventions of 12 August 1949, and relating to the protection of victims of international armed conflicts. United Nations Human Rights: Office of the High Commissioner. https://www.ohchr.org/EN/ProfessionalInterest/Pages/ProtocolI.aspx

Owen, B. (2008, May 17). Auschwitz: Fact and metaphor. Northern Illinois University: University Honors Capstone Projects.

Pika, J. A., Maltese, J. A., \& Rudalevige, A. (2020). The politics of the presidency (10th ed.). SAGE Publishing.

Popp, R. K., \& Mendelson, A. L. (2010). 'X'-ing out enemies: Time magazine, visual discourse, and the war in Iraq. Journalism: Theory, Practice \& Criticism, 11(2), 203-221. https://doi.org/10.1177/1464884909355913.

Reyes, A. (2011). Strategies of legitimatization in political discourse: From words to action. Discourse \& Society, 22(6), 781-807. https://doi.org/10.1177/0957926511419927.

Rogers, K., \& Baker, P. (2020, March 14). On a Saturday night in Florida, a presidential party became a coronavirus hot zone. The New York Times. https://www.nytimes.com/2020/03/14/us/politics/trump-coronavirus-mar-a-lago.html 
Rogers, S. (2018, May 25). The shop that spawned 78 Trump tattoos. Daily Beast. https://www.thedailybeast.com/the-shop-that-spawned-78-trump-tattoos?ref=scroll

Rosentiel, T. (2008, March 19). Public attitudes toward the war in Iraq: 2003-2008. Pew Research Center. https://www.pewresearch.org/2008/03/19/public-attitudes-toward-thewar-in-iraq-20032008/

Rothman, L. (2017, September 8). Behind the Osama bin Laden 'Red X' TIME Cover. TIME. https://time.com/4307301/5-years-osama-bin-laden/

Rowland, R. (2009). The narrative perspective. In J. A. Kuypers (Ed.), Rhetorical criticism: Perspectives in action (pp. 117-142). Littlefield Publishers.

Rubenstein, D. (1989). The mirror of reproduction. Political Theory, 17(4), 582-606. https://doi.org/10.1177/009059178901700407.

Rubin, G. (2020). Presidential rhetoric on terrorism under Bush, Obama, and Trump: Inflating and calibrating the threat after 9/11. Palgrave MacMillan. doi:10.1007/978-3-03030167-5_1

Sanger, D., \& Shanker, T. (2003, April 16). A nation at war: White House; Bush says regime in Iraq is no more: Syria is penalized. The New York Times. https://www.nytimes.com/2003/04/16/world/nation-war-white-house-bush-says-regimeiraq-no-more-syria-penalized.html.

Schmidle, N. (2011, August 1). Getting bin Laden: What happened that night in Abbottabad. The New Yorker. https://www.newyorker.com/magazine/2011/08/08/getting-bin-laden

Smith, S. A. (2018, April 16). Abe returns to Mar-a-Lago. Council on Foreign Relations. https://www.cfr.org/blog/abe-returns-mar-lago 
Smithsonian Institution. (2020). The Lincoln White House: Grand Presidential Party. National Museum of American History: Behring Center. https://americanhistory.si.edu/lincoln/lincoln-white-house

Souza, P. (2011). The Situation Room. Time 100 Photos. http://100photos.time.com/photos/petesouza-situation-room

Stramer, J. (2020). The language of war: George W. Bush's discursive practices in securitising the western value system in the 'War on Terror'. In B. Brecher (Ed.), The new order of war (Vol. 64, pp. 35-47). Rodopi.

Strauss, V. (2012, January 10). Ravitch: No Child Left Behind and the damage done. The Washington Post. https://www.washingtonpost.com/blogs/answer-sheet/post/ravitch-nochild-left-behind-and-the-damage-done/2012/01/10/gIQAR4gxoP_blog.html

Talmon, S., \& Heipertz, M. (2020). The U.S. killing of Iranian General Qasem Soleimani: Of wrong trees and red herrings, and why the killing may be lawful after all. Social Science Research Network. Universität Bonn: Institute for Public International Law.

Thomas, M., \& Buckmaster, L. (2010, December 15). Paternalism in social society: When is it justifiable? Parliament of Australia: Research Papers 2010-11. https://www.aph.gov.au/About_Parliament/Parliamentary_Departments/Parliamentary_Li brary/pubs/rp/rp1011/11rp08\#_Toc280187797

The Toledo Blade. (2011, May 4). Newspaper front pages on bin Laden's death. The Toledo Blade. https://www.toledoblade.com/gallery/newspaper-front-pages-on-bin-laden-death Trump, D. J. (2017, January 20). The Inaugural Address. Trump White House Archives. https://trumpwhitehouse.archives.gov/briefings-statements/the-inaugural-address/ 
Trump, D. (2017, May 21). President Trump's Speech to the Arab Islamic American Summit. The White House. https://www.whitehouse.gov/briefings-statements/president-trumpsspeech-arab-islamic-american-summit/

Trump, D. (2020, January 3). Remarks by President Trump on the killing of Qasem Soleimani. Trump White House Archives. https://trumpwhitehouse.archives.gov/briefingsstatements/remarks-president-trump-killing-qasem-soleimani/

Tulis, J. K. (1987). The rhetorical presidency. Princeton University Press.

United States Census Bureau. (2020). U.S. and World Population Clock. United States Census Bureau. https://www.census.gov/popclock/

United States Government Accountability Office. (2019). Report to Congressional requesters: January 2019 Presidential travel. United States Government Accountability Office. Retrieved from https://www.gao.gov/assets/700/696512.pdf

Villenueve, M., \& Hinnant, L. (2020, April 6). NYC virus deaths exceed 4,000, topping toll for 9/11 attacks. Associated Press. https://apnews.com/6e506c4f105670b8fa8eb5531aadf2c1

Walcott, J., \& Holland, S. (2017, April 7). Trump ordered Syrian air strike before dinner with Xi. Reuters. https://www.reuters.com/article/us-mideast-crisis-syria-trump/trump-orderedsyrian-air-strike-before-dinner-with-xi-idUSKBN1792W4

Walt Disney Studios. (23, October 2019). Disney’s Maleficent: Mistress of Evil| “\#1 Movie in the World" Spot [Video]. YouTube. https://www.youtube.com/watch?v=xxd4LpZK2nA

Wander, P. (1997). The rhetoric of American foreign policy. In M. J. Medhurst, R. L. Ivie, P. Wander, \& R. L. Scott (Eds.), Cold War rhetoric: Strategy, metaphor, and ideology (pp. 153-183). Michigan State University Press. 
Ward, A. (2020, March 31). The coronavirus has now killed more people in the US than the 9/11 terror attacks. Vox. https://www.vox.com/2020/3/31/21199495/coronavirus-death-rateseptember-11-terror-attacks

Warner Bros. Pictures. (10, October 2013). Gravity - \#1 Movie in the World [Video]. YouTube. https://www.youtube.com/watch?v=nr3w8TkVhOc

The White House Archives: President George W. Bush. (n.d.). The president's cabinet. The White House Archives: President George W. Bush. https://georgewbushwhitehouse.archives.gov/government/cabinet-room.html

White House Historical Association. (n.d.). The East Room. Retrieved from The White House Historical Association: https:/www.whitehousehistory.org/white-house-tour/the-eastroom

Winthrop, J. (1630). City upon a Hill. Retrieved from The Gilder Lehrman Institute of American History.

Zarefsky, D. (2004). Presidential rhetoric and the power of definition. Presidential Studies Quarterly, 34(3), 607-619. https://doi.org/10.1111/j.1741-5705.2004.00214.x. 